\title{
GEOLOGIC MAP OF THE MOUNT ADAMS VOLCANIC FIELD, CASCADE RANGE OF SOUTHERN WASHINGTON
}

\author{
By Wes Hildreth and Judy Fierstein
}

When I climbed Mount Adams [17-18 August 1945] I think I found the answer to the question of why men stake everything to reach these peaks, yet obtain no visible reward for their exhaustion... Man's greatest experience-the one that brings supreme exultationis spiritual, not physical. It is the catching of some vision of the universe and translating it into a poem or work of art...

William O. Douglas

Of Men and Mountains

\section{INTRODUCTION}

One of the dominating peaks of the Pacific Northwest, Mount Adams, stands astride the Cascade crest, towering $3 \mathrm{~km}$ above the surrounding valleys. The icecapped 3742-m $\left(12,276^{\prime}\right)$ stratovolcano has for centuries been called Pah-to by the region's indigenous people, who hold the mountain sacred as a symbol of continuity and a source of prosperity and inspiration. Comparable reverence helped secure inclusion of most of the great cone in the national wilderness system in 1964. Far less prominent than the central stratovolcano is an extensive field of subdued volcanic centers composing its heavily forested lowland periphery. Before the present investigation, little was known about the eruptive history, the distribution of eruptive vents, or the frequency, composition, and explosivity of past volcanic activity, for either the focal stratocone or the surrounding volcanic field. Our mapping began in 1981 as a Congressionally mandated assessment of the mineral- and geothermal-resource potential of the Mount Adams Wilderness (Hildreth and others, 1983). The project expanded to include assessment of the volcanic hazards and, as the long-lived eruptive complexity of the area became appreciated, it evolved into a fundamental investigation of how volcanoes work.

\section{PHYSIOGRAPHY AND ACCESS}

Mount Adams lies $50 \mathrm{~km}$ north of the Columbia River, $50 \mathrm{~km}$ due east of Mount St. Helens, $75 \mathrm{~km}$ south-southeast of Mount Rainier, and $85 \mathrm{~km}$ southwest of the city of Yakima (fig. 1). It is by far the largest volcano in the Pacific Northwest, and, among Cascade stratocones, it is surpassed in volume only by Mount Shasta. The central cone, predominantly andesitic, covers about $600 \mathrm{~km}^{2}$, and the peripheral, largely basaltic, volcanic field covers an additional $650 \mathrm{~km}^{2}$. The upper part of Mount Adams consists of glaciers, rugged ridges, barren moraines, and alpine meadows, but below an elevation of about $1950 \mathrm{~m} \mathrm{(6400')} \mathrm{most} \mathrm{of} \mathrm{the} \mathrm{landscape} \mathrm{is} \mathrm{mantled}$ by dense forests and huckleberry thickets. Ten radial glaciers and the summit icecap today cover only about 2.5 percent $\left(16 \mathrm{~km}^{2}\right)$ of the cone, but in latest Pleistocene time $(25-11 \mathrm{ka})$ as much as 80 percent of Mount Adams was under ice. The volcano is drained radially by numerous tributaries of the Klickitat, White Salmon, Lewis, and Cispus Rivers (figs. 1,2), all of which ultimately flow into the Columbia.

Most of Mount Adams and a vast area west of it are administered by the U.S. Forest Service, which has long had the dual charge of protecting the Wilderness Area and of providing a network of logging roads almost everywhere else. The northeast quadrant of the mountain, however, lies within a part of the Yakima Indian Reservation that is open solely to enrolled members of the Yakima Nation and to permittees approved by the Yakima Tribal Council. The only settlements near Mount Adams are the halcyon villages of Trout Lake and Glenwood, around each of which most of the land is privately owned and devoted to agriculture or forestry. Access is generally easy, except to the Reservation and to parts of the heavily vegetated west flank of the stratocone. Within the roadless Wilderness Area, several foot trails climb through the woods to alpine areas above timberline, and mountaineering tracks have been worn as high as the $3000-\mathrm{m}$ level on the north and south ridges of Mount Adams. Other approaches to the summit (Beckey, 1974) require technical ascent of icefalls or steep cleavers of rubbly andesite.

\section{METHODS}

The geologic mapping took place during the summers of $1981-85$ and $1987-88$, followed by reexamination of troublesome areas in 1991 and 1992. A total of 380 days, representing 2-12 weeks in each of nine seasons, was devoted to fieldwork, most of it backpacking or based in public campgrounds. Contacts between map units were walked out, located by inspection, and plotted directly on 1:24,000-scale topographic maps in the field. Owing to glacial erosion and heavy forest cover, aerial photographs were seldom useful. In the office, the field sheets were reduced to $1: 50,000$ and the data manually transferred to a composite mylar basemap prior to computer scanning, editing, and colorization. In the field, most basaltic, dacitic, and olivine-andesitic units are readily distinguishable with the aid of a handlens, but distinctions among pyroxene-andesites of various ages typically required additional microscopic and chemical data (see Description of Map Units, below). 
The boundaries of the geologic map are somewhat but not entirely arbitrary. As our fundamental objective was to understand the Quaternary magmatic system that produced Mount Adams and the contemporaneous basaltic centers arrayed around it, the Oligocene and Miocene "basement" rocks were essentially ignored. Our strategy was to establish the distribution, composition, approximate volume, age, and sequence of eruptive products from the central stratovolcano and from a peripheral zone of coeval basaltic vents broad enough to assure representation of the full compositional array of products that erupted from the Quaternary magmatic system. A scattering of additional Quaternary centers (mostly basaltic) continues well beyond the map limits in most directions, but Quaternary vent density (vent abundance per unit area) decreases appreciably to the west, north, and south (Luedke and others, 1983). In this respect, the Mount Adams volcanic field as here depicted appears to have a certain coherence and integrity. Our eastern boundary is the canyon of the Klickitat River, a long-lived barrier never crossed by Adams-derived lavas and beyond which no vents are known to be younger than $0.63 \mathrm{Ma}$ (Uto and others, 1991). The map's southwestern boundary is somewhat more arbitrary, as the duration of activity in the adjacent Indian Heaven volcanic field appears to have been more or less coeval (Hammond and Korosec, 1983) with the middle Pleistocene to Holocene eruptive history of Mount Adams. Vent density, however, appears to reach a minimum in the transition zone near our southwest map boundary and increases sharply again toward Indian Heaven, a few kilometers beyond it (Luedke and others, 1983; Walsh and others, 1987; Smith, 1993).

\section{GEOLOGIC SETTING}

The Mount Adams volcanic field is a component of the Cascade magmatic arc, the upper-crustal manifestation of an elongate domain of subcrustal and deep-crustal partial melting induced by processes related to northeastward subduction of oceanic lithosphere beneath the margin of North America. The active Cascade arc stretches today from southern British Columbia to northern California and in pre-Quaternary time extended still farther southeast. In southern Washington, the arc has been intermittently active since Eocene time, depositing a great thickness of volcanic and derivative clastic strata that constitute the bulk of the present-day Cascade landscape. In middle Miocene time (17-14 Ma), numerous flood basalts of the Columbia River Basalt Group poured westward from vents in eastern Washington, banking against and locally invading the Cascade arc in the region of modern Mount Adams. Much later, the Mount Adams volcanic field was constructed over a Pleistocene erosion surface of moderate to rugged relief cut into both Tertiary assemblages.

Folds and faults of apparent pre-Quaternary age are numerous and widespread in both the Tertiary arc rocks and the Columbia River Basalt Group in the Mount Adams region (Walsh and others, 1987; Smith, 1993), but overlying rocks of the stratocone and its surrounding volcanic field remain undeformed. Concentrations of Quaternary vents along north-trending belts (Hammond, 1980) tens of kilometers long (in the Indian Heaven, Mount Adams, and Simcoe Mountains volcanic fields), as well as local alignments of comagmatic vents, suggest influence by buried structures or by regional north-south compression.

Mount Adams lies near the center (fig. 1) of an extraordinarily extensive region of fundamentally basaltic Quaternary volcanism in southern Washington (Luedke and others, 1983; Walsh and others, 1987; Smith, 1993). The Mount Adams volcanic field (0.9-0 Ma; more than 60 vents) overlaps eastward with the slightly older Simcoe Mountains volcanic field (4.5-0.6 Ma; more than 80 vents; Sheppard, 1967a; Uto and others, 1991), and it merges southwestward into the largely coeval Indian Heaven volcanic field (0.8-0 Ma; more than 40 vents; Hammond and others, 1976; Korosec, 1989). North of the map area, a cluster of Quaternary basaltic centers (in the Walupt Lake area) separates Mount Adams from the Goat Rocks stratovolcano, an eroded andesitic center active in Pliocene and early Pleistocene time (Swanson and Clayton, 1983). South of the map area, widely scattered basaltic centers near Gilmer and White Salmon (fig. 1) mark a 50-km-wide zone of relatively limited Quaternary volcanism that separates the Mount Adams volcanic field from another surrounding Mount Hood. Altogether, from the volcanic front near Mount St. Helens (fig. 1) to the easternmost Pleistocene basaltic centers near Goldendale, the zone of Quaternary volcanic activity in southern Washington is $150 \mathrm{~km}$ wide!

The continental crust below the Mount Adams region is about 40-45 $\mathrm{km}$ thick (Mooney and Weaver, 1989), but its composition is poorly known. Beneath the thick accumulation of Tertiary arc rocks exposed, the crust is likely to be a tectonic aggregation of accreted oceanic and island-arc terranes with accretionary-prism and forearcbasin sedimentary rocks (Stanley and others, 1987; Miller, 1989), all pervasively intruded, underplated, and stitched together by intrusive rocks of the Tertiary to Quaternary arc. In the Mount Adams region, however, no preOligocene rocks are exposed, and the nearest pre-Tertiary exposure is about $40 \mathrm{~km}$ north (Ellingson, 1972; Miller, 1989).

The depth of the oceanic plate subducting beneath the Cascades of southern Washington is not established. The inclined seismic zone used to locate the subducting slab below coastal Washington and Puget Sound (Weaver and Baker, 1988) is not detectable farther east owing to a lack of earthquakes deeper than $70 \mathrm{~km}$. It seems required that the downgoing plate has to make a major geometrical accommodation of some kind here, however, because the trace of the plate boundary on the seafloor changes strike from northerly off Oregon to northwesterly off British Columbia. Weaver and Baker (1988) summarized the seismic data available and suggested that, rather than tearing, the slab arches smoothly, convexupward beneath the Seattle area, bending around from a northeast-dipping limb in British Columbia and northern Washington to an east-southeast-dipping limb beneath southern Washington. This configuration is last detectable about $100 \mathrm{~km}$ west of Mount Adams, where at a depth of $60-70 \mathrm{~km}$ the slab dips approximately $25^{\circ}$; if 
this inclination persists in the aseismic region farther east, the subducting plate would be about $100 \mathrm{~km}$ deep beneath Mount Adams.

Compared to many subduction settings elsewhere, the oceanic plate descending beneath southern Washington is young (less than $10 \mathrm{Ma}$ ), hot, thin, and shallow. The plate-convergence rate is slow $(4 \mathrm{~cm} / \mathrm{yr})$, and the relative convergence azimuth $\left(59^{\circ}-68^{\circ}\right.$; Savage and Lisowski, 1991) is oblique to the plate boundary. As both the $60-\mathrm{km}$ (deepest definable) contour on the descending slab (Weaver and Baker, 1988) and the (weakly defined) volcanic front (fig. 1) strike about N. $25^{\circ} \mathrm{E}$., the obliquity of convergence in southern Washington is extraordinary. In combination with the bending of the slab itself, its shallow oblique impingement against the base of the continental plate may be implicated in giving rise to the remarkably broad belt of compositionally diverse basalts in southern Washington (Leeman and others, 1990). The area is strikingly anomalous in that lowpotassium tholeiites, calc-alkaline basalts; and alkalic basalts coexist across virtually the entire $150-\mathrm{km}$ width of the Quaternary volcanic zone. Moreover, the zone is unique in the Cascades in having coeval andesite-dacite stratovolcanoes (Mount Adams and Mount St. Helens) situated $50 \mathrm{~km}$ across-arc from each other. The crustal stress field changes across the zone, the direction of maximum horizontal compression shifting from about $30^{\circ}$ in the coastal region and near Mount St. Helens to essentially north-south near and east of Mount Adams (Zoback, 1990). A strongly coupled shallow plate boundary may favor temporal as well as spatial shifts in stress orientation, perhaps affecting permeability of the lithosphere to the ascent of magmas from a range of depths and sources.

\section{ERUPTIVE HISTORY}

The basic documentation of the eruptive history of the Mount Adams volcanic field is the geologic map itself and the accompanying description of map units. We have distinguished 132 Quaternary eruptive units, of which 54 are basaltic, 62 andesitic, and 16 dacitic. The only rhyolites exposed ( $\mathrm{Trc}, \mathrm{Trg}, \mathrm{Trm}$ ) are of pre-Quaternary age. Several of the basaltic and andesitic map units are stacks or shingled shields of chemically and mineralogically similar lava flows that could represent extended or repeated episodes of eruption. Most units (including all of the dacites), however, are thought to be products of discrete eruptive events of limited duration (a few weeks to several years).

Potassium-argon (K-Ar) age determinations by M.A. Lanphere (Hildreth and Lanphere, 1994) are given for more than half of the eruptive units described. The oldest lavas exposed in the central stratocone complex are andesites and dacites dated at 520-500 ka; several peripherally erupted basalts are also of about that age $(550-500 \mathrm{ka})$. The only units older are a compositionally varied cluster of centers at the southern margin of the volcanic field (about $625 \mathrm{ka}$ ) and several southeasterly lavas (700-940 ka) exposed near Glenwood that are spatially, compositionally, and temporally transitional to the adjacent Simcoe Mountains volcanic field (4.5$0.6 \mathrm{Ma}$; Uto and others, 1991).

\section{LONG-LIVED CENTRAL STRATOCONE SYSTEM}

The original focus of the stratocone at $520-500 \mathrm{ka}$ was $5 \mathrm{~km}$ southeast of the modern summit, above the present-day Ridge of Wonders and the upper parts of Hellroaring and Big Muddy Creeks. Informally referred to here as the Hellroaring volcano, its gutted remnants are well-exposed and mapped as units ahv, abh, dth, and dts, all of which are cut by conspicuous dikes of unit adh. By $460 \mathrm{ka}$, the eruptive focus appears to have shifted to a position beneath the modern cone, the probable source of the thick basal pile of andesitic lavas (aws) exposed in the canyons of Cascade Creek and the White Salmon River. Since that time, recurrent central activity has built an encircling apron of andesitic and dacitic lavas that extends about $15 \mathrm{~km}$ in all directions from the present summit. Although breaks in activity as long as 30 k.y. are permitted by the K-Ar data, few (if any) repose intervals are likely to have been that long. As the dominant focus for ascent and eruption of evolved (nonbasaltic) magma, the Mount Adams stratocone has remained potentially active throughout its entire half-million-year-long history.

Glaciers rapidly erode high-standing fragmental stratocones, and during the interval just preceding construction of the modern summit cone Mount Adams had been reduced to an elevation of about $2500 \mathrm{~m}$ $\left(8000^{\prime}\right)$. Subsequently, the prolonged eruptive episode (35-10 ka) that built today's central edifice (app, aas) covered completely the long-lived vent region for the surrounding apron of centrally derived lava flows that had erupted between $460 \mathrm{ka}$ and $50 \mathrm{ka}$. If the eruptive pattern of the last 35,000 years is a reliable analog, however, the hundreds of radially emplaced lavas constituting that apron issued not only from successive summit vents but from an array of effusive flank vents, which were higher than about $2100 \mathrm{~m}$ and mostly within $5 \mathrm{~km}$ of the summit.

\section{THE YOUNGEST ERUPTIONS}

There have been no historical eruptions in the Mount Adams volcanic field, and none of the Holocene lava flows has been demonstrated to be younger than 3500 yr B.P., the age of a widespread and distinctive ash layer (layer Ye) erupted from Mount St. Helens (Mullineaux, 1986). Among the eight Holocene eruptive units mapped, only the windswept lavas of units agg and abr, high on barren ridgecrests, are conceivably younger than the 3500-yearold ash.

In an alpine-meadow section $6 \mathrm{~km}$ southeast of the summit of Mount Adams, however, regional layer Ye is overlain by four lenses of andesitic lithic-crystal ash (each as thick as $1 \mathrm{~cm}$ ) and a single $3-$ to $9-\mathrm{cm}$ layer rich in andesitic scoriae (as coarse as $2 \mathrm{~cm}$ ), all clearly of local derivation. The scoria fall and three of the four ash lenses also overlie ash layers of set $\mathrm{P}$ from Mount St. Helens (approximately 2500 years old), but all underlie St. Helens layer We (A.D. 1482; Mullineaux, 1986). None of these late Holocene tephras, which apparently represent the most recent eruptions of the Mount Adams volcanic field, has been tied to a specific eruptive vent. Likely candidates are the vents for map units agg and abr; an unlikely 
candidate is the summit vent, where the small cone of fragmental andesite (aas) capping the main edifice is iceravaged, $\mathrm{K}-\mathrm{Ar}$ dated at $15 \pm 8 \mathrm{ka}$, and probably of early Holocene age at the youngest.

All eight of the unequivocally Holocene eruptive units mapped, each consisting predominantly of lava flows, issued from flank vents at $2100-2600 \mathrm{~m}\left(6800^{\prime}-8500^{\prime}\right)$, relatively high on the main edifice. Seven of the eight are andesitic (54.5-62 percent $\mathrm{SiO}_{2}$ ) and vented effusively; the lone basalt (unit btc; 49 percent $\mathrm{SiO}_{2}$ ) built the only Holocene cinder cone at Mount Adams.

\section{THE MAFIC CORRIDOR}

The stratovolcano is part of a north-trending zone of vents that has produced about 90 of the 132 Quaternary eruptive units mapped and more than 90 percent of the volume of the volcanic field. A $6-\mathrm{km}$-wide belt extending more than $50 \mathrm{~km}$ (from Walupt Lake to Laurel) contains virtually all of the late Pleistocene (10$132 \mathrm{ka}$ ) and Holocene vents and most of the older ones. With few exceptions, the map units that erupted outside this zone came from (1) middle Pleistocene vents around the Trout Lake valley, (2) still older centers near the Klickitat River, or (3) vents in the Indian Heaven volcanic field. Except on the andesitic stratocone itself, nearly every unit that erupted inside the zone, irrespective of age, consists of basalt or olivine-andesite. Within $5 \mathrm{~km}$ of Mount Adams' summit, however, only a single basalt has ever succeeded in passing through the andesitic focus during its long existence (since $520 \mathrm{ka}$ ). That lone penetration (by unit brc) took place at $63 \mathrm{ka}$, toward the end of one of the longest recognized lulls in central andesitic activity. Basaltic vents are scattered elsewhere, too, but the elongate vent corridor evidently reflects a belt of especially concentrated injection of the crust by mantlederived basalts. For the past half-million years, the volumetrically largest throughput of magma in Washington has been along this corridor, and the production rate was greatest of all near its midsection-at Mount Adamswhere magmatic fractionation, assimilation, and mixing reach a maximum, and where ascent of basaltic magmas is effectively suppressed. It is important to appreciate that andesitic activity in the focal region and coeval basaltic activity on the periphery have coexisted for half a million years. The contrasting products are interstratified, and even basaltic shield volcanoes like King Mountain and Goat Butte are sandwiched between andesitic lavas from Mount Adams.

\section{COMPOSITIONS OF THE ERUPTIVE PRODUCTS}

At all stages, the central cone has been constructed predominantly of porphyritic pyroxene andesite (56-62 percent $\mathrm{SiO}_{2}$ ) with or without subordinate phenocrysts of olivine. Most of these rocks contain 15-35 percent of conspicuous plagioclase phenocrysts, but a variety of relatively phenocryst-poor dacites and olivine-andesites is also present. All the basalts $\left(47-53\right.$ percent $\left.\mathrm{SiO}_{2}\right)$, inside or outside the corridor, contain olivine, and many have plagioclase and clinopyroxene, as well. No Quaternary product of the Mount Adams volcanic field has pheno- crysts of quartz, alkali feldspar, or biotite, and amphibole is present in only two (alr, dnc) of the 132 Quaternary eruptive units described. Mount Adams was long believed to be a monotonously andesitic volcano having only a limited compositional range, but we have found its eruptive products to range continuously from 52 to 68.5 percent $\mathrm{SiO}_{2}$ on the main cone and from 47 to 61 percent $\mathrm{SiO}_{2}$ on the periphery. Especially remarkable is the variety of basalts (alkalic, low-potassium tholeiitic, and calcalkaline) that erupted along the corridor during late Pleistocene time in close proximity to each other and to Mount Adams. The potentially mixed parentage implicit in such proximity seems apparent in the varied andesites of the field, which range, for example, at 55 percent $\mathrm{SiO}_{2}$, from 0.8 to 2.3 percent $\mathrm{K}_{2} \mathrm{O}$.

Dacitic magma (63-68.5 percent $\mathrm{SiO}_{2}$ ) is known to have erupted at least 19 times in the history of the volcanic field. Two dacite lavas (dnc, ddc) in the southeast quadrant of the map predate inception of the stratovolcano. Fourteen other dacites range in age from $516 \mathrm{ka}$ to $115 \mathrm{ka}$ and are well distributed all around the main cone. Most vents are concealed by younger units, but nearly all (except perhaps unit dol) appear to have issued from vents on the upper flanks of the cone. Dacitic eruptive products include 5 large coulees (dol, dhd, dss, ddc, dbc), at least 10 lesser lava flows, a pumiceous pyroclastic flow (dth), a spatter-fed agglutinate pile (proximal part of unit dcc), and breccia sheets associated with thick lava flows (dts). A single dacite lava flow is recognized near the base of the pile of generally altered andesites comprising the Hellroaring volcano (see unit ahv), and, similarly, lone dacites are distinguishable chemically within each of the heterogeneous, generally andesitic, map units aws and adh. The only dacite at Mount Adams known to be younger than $100 \mathrm{ka}$ is not exposed; found only as nearly aphyric clasts in the Holocene till and avalanche debris of Adams Glacier, it may represent a summit extrusion concealed by the summit icecap (see unit aas).

\section{STYLES OF ERUPTION}

In contrast to the many explosive dacite eruptions of Mount St. Helens, activity at Mount Adams has been dominantly effusive, of low to moderate explosivity, and has produced few regionally extensive ashfalls, few fragmental flow deposits, and only local devastation. Dacite eruptions typically involve wide dispersal of pumice and ash, but at Mount Adams all exposed dacites are more than 100,000 years old, and any associated ash layers deposited within the area mapped have subsequently been eroded away or obscured by younger deposits. Much more common in the Mount Adams area, eruptions of basalt or mafic andesite have characteristically produced shields of thin shingled flows of fluid lava, cones of nearvent scoria and spatter, and long tongues of effusive or fountain-fed lava that funnelled into and along stream valleys. On the other hand, eruptions of silicic andesite, also common here, have rarely constructed scoria cones; instead, each eruption has produced one or a few effusive lava flows-typically thick, viscous, and blocky. These slow-moving viscous lavas are generally less responsive to topography than the more fluid basalts, but 
once confined in canyons, voluminous andesite (and dacite) lavas have flowed farther than $10 \mathrm{~km}$ downstream (see units amc, apc, and dcc). A few intracanyon basalts (bgb, bic, bsc) have gone $25-45 \mathrm{~km}$. Ashfall from these andesitic and basaltic eruptions is seldom voluminous or widespread; $10 \mathrm{~km}$ downwind from a vent, for example, an ash layer thicker than $1 \mathrm{~cm}$ would be exceptional. Wind and glacial erosion have stripped any Pleistocene fallout layers from the slopes of Mount Adams; the Holocene layers locally preserved in alpine meadows (3-10 km from likely vents) are typically only $0.5-5 \mathrm{~cm}$ thick and consist of andesitic crystal-lithic ash, a few also having scoriae as large as $1-2 \mathrm{~cm}$.

Summit eruptions of Mount Adams involve the special conditions imposed by a glacial icecap and by $25^{\circ}-50^{\circ}$ slopes on all sides. Spatter and scoria layers indicate episodes of lava fountaining and strombolian activity; on the other hand, ash-rich fragmental deposits containing angular glassy blocks of poorly vesiculated andesite indicate phreatomagmatic and steam-blast eruptions promoted by interaction of rising magma with meltwater from the icecap (see units aas and app). Effusive and fountain-fed lavas that overflowed the summit rim built steeply dipping radial stacks of thin flows, each dominated by rubbly oxidized zones of scoriaceous flow-breccia. Some flows lost coherence on steep slopes and transformed into lava-debris avalanches; resulting deposits are well exposed near Sunrise Camp (abh).

Pyroclastic-flow deposits are rare at Mount Adams. Dacitic unit dth is the only pumiceous pyroclastic-flow deposit exposed. Disintegrating lava flows produced several ash-rich nonpumiceous breccia sheets (abh, dts) comparable to andesitic block-and-ash-flow deposits elsewhere. One or two scoria flows are exposed proximally on Roosevelt Cliff and the headwall of Klickitat Glacier, and rare darkgray outcrops of lithic-rich andesitic ash-flow material are associated with lava flows of unit asc on the lower west slope of Mount Adams.

Some stratovolcanoes construct broad encircling aprons made up principally of debris-flow deposits (lahars) and lesser fractions of alluvial, pyroclastic-flow, and avalanche material. Such fragmental debris has certainly been generated here, as well, but deposits are inconspicuous, and the extensive apron surrounding Mount Adams consists predominantly of lava flows. From its inception, Mount Adams rose above a canyon-cut terrain having a climate with high precipitation and runoff. Most debris-flows (syneruptive or otherwise) have funnelled directly into surrounding river valleys where the deposits are rapidly reworked and carried away by normal fluvial processes. Repeated glacial advances have also helped to scour fragmental veneers from the volcano's flanks and, medially, from the radial drainage system.

\section{VOLCANIC HAZARDS}

The geologic record of the past several thousand years suggests that the likelihood of Mount Adams erupting in the next century or so is smaller than for Mounts Hood, Rainier, or St. Helens, the other stratovolcanoes nearby.
In contrast to those centers, the Mount Adams region is nearly aseismic, virtually lacking detectable earthquakes at any depth (Norris, 1991). The small degraded cone crowning the summit of Mount Adams is $\mathrm{K}-\mathrm{Ar}$ dated at $15 \pm 8 \mathrm{ka}$, and no evidence has been found of summit eruptions any younger. Holocene lava flows have issued from 8 discrete flank vents, only one of which also built a scoria cone (see unit btc). At least six of these eruptions took place before $3.5 \mathrm{ka}$, the age of regionally dispersed tephra layer Ye from Mount St. Helens; the two smallest of the Holocene units (abr, agg) just might be younger, but this is unproven. A few thin $(0.5-5 \mathrm{~cm})$ layers of andesitic fallout, found only on the southeast flank of Mount Adams, overlie the 3.5-ka ash layer; they represent the most recent activity here-weak ashclouds of limited dispersal-probably all more than 1000 years old.

Eruptions at Mount Adams in the last 10,000 years have thus been relatively inexplosive, mostly effusive, and few. The principal Holocene eruptive product has been a series of slow-moving lava flows; some of these extended 7-12 km to the base of the cone, overrunning sites of several modern logging roads but never approaching areas currently inhabited. For several millennia the system has been virtually quiescent, and the average eruptive recurrence interval for Holocene time exceeds 1000 years. Weak fumaroles can linger long after magma crystallizes, so those atop Mount Adams should be apprehended as a reminder, not a warning.

From the broader perspective of the whole volcanic field, eruption sites of the last 150,000 years have been limited entirely to the stratocone and the contiguous north-south corridor of mafic vents. Corridor eruptions have been less frequent than on the main cone, but occasional outpourings of mafic andesite (asb, asm, abb) and basalt (units bsb and bsc and the.Walupt Lake cone just north of the map boundary) devastated large areas during late Pleistocene time. The possibility of such eruptions from mafic vents north and south of Mount Adams should not, therefore, be discounted. Although of lower probability than renewed activity of Mount Adams itself, major eruptions of fluid lava have flooded the valleys of the Klickitat, White Salmon, and Cispus Rivers relatively recently and could do so again. Moreover, the Trout Lake lowland is at risk not only from the Mount Adams vent corridor but from the nearby Indian Heaven volcanic field, out of which basalts (bhs, blg, blc, bic) have repeatedly poured eastward along Cave and Trout Lake Creeks.

If patterns of past activity provide a reasonable basis for anticipating future eruptive styles and conditions, then fallout of volcanic ash during a future outbreak on or near Mount Adams might be troublesome but is unlikely to be catastrophic. Eruptions of the last 100,000 years have been exclusively andesitic or basaltic; such events have produced lavas and near-vent cinder cones, but there is no record of an Adams-derived ash layer thicker than $2 \mathrm{~cm}$ extending more than $10 \mathrm{~km}$ from source. Ironically, on the flanks and periphery of Mount Adams (except within a kilometer or two of known vents), wherever andesitic ash layers have been found, coexisting dacitic 
ash layers from Mount St. Helens are thicker. Even during wind conditions driving andesitic ashclouds directly toward Trout Lake or Glenwood $(22 \mathrm{~km}$ south and $25 \mathrm{~km}$ southeast of the summit, respectively), ash accumulation in those villages would be unlikely to exceed $1 \mathrm{~cm}$, possibly sufficient to foul machinery but not enough to collapse roofs. Mount Adams has clearly not been a very explosive volcano; no eruption even approaching the explosivity of historical events at Mount St. Helens has taken place here in more than 100,000 years.

The greatest hazard at Mount Adams, in common with many other large andesitic stratovolcanoes (Crandell, 1971; Scott and others, 1992), is not from volcanic activity as such but from debris avalanches and debris flows of various origins. A summit eruption or even a shallow intrusion beneath the icecap could promote rapid melting of snow and ice that might lead to high-velocity floods cascading down steep walls of the cone. Far more frequent are glacier-outburst floods unrelated to magmatic activity; commonest in summer or early autumn, abrupt outbursts of water stored within or beneath glaciers can apparently take place in response to hot weather or heavy rainfall or, sometimes, without any apparent triggering mechanism (Richardson, 1968). At Mount Adams, a flood of any origin is expected to bulk rapidly into a potentially destructive debris flow by incorporation of volcanic rubble, alluvium, and till from steep undercut moraines. In the 1980's alone, outburst floods from Avalanche, Adams, and Rusk Glaciers generated debris flows that left bouldery levees and swaths of destruction extending 4-15 km down Cascade, Adams, and Big Muddy Creeks. Unrecorded but similar events in the recent past devastated upper reaches of Muddy Fork, the Lewis River, and Morrison, Salt, Hellroaring, and Little Muddy Creeks. Few such nonvolcanic flood-initiated debris flows threaten more than wildlife and imprudent stream-bank campers, but in 1988 two such events damaged the headworks of Hellroaring Ditch (a historical structure still critical to irrigation of Glenwood-Camas Prairie agricultural lands). An unusually voluminous debris flow could take out the loggingroad bridges on any of the streams just mentioned. A summit eruption would certainly pose the threat of such an event.

Debris avalanches resulting from failure of steep upper slopes of the main cone pose an ever-present danger, potentially the most severe hazard at Mount Adams. Surrounding the summit, stacks of dozens of thin lava flows dip radially outward at $25^{\circ}-35^{\circ}$. Separated by their own scoriaceous breccia zones, which are typically 1$5 \mathrm{~m}$ thick and rich in clay minerals produced by reaction with hydrothermal fluids, such flows provide natural slip surfaces for potential dip-slope failure. Debris avalanches of small volume commonly break loose from glaciated headwalls, especially from the steep solfatarically altered zones adjacent to Adams, Wilson, Rusk, Klickitat, and Avalanche Glaciers. Conspicuous deposits rich in internally stratified megaclasts are present below Adams and Rusk Glaciers, at Devils Gardens below Lyman and Wilson Glaciers, and in upper Salt Creek where a modest avalanche in May 1921 spread over an area of about $4 \mathrm{~km}^{2}$ (Byam, 1921; Vallance, 1986). By far the larg- est such deposit recognized at Mount Adams is the "Trout Lake Mudflow" (see unit daf) described by Jones (1960), Hopkins (1976), and Vallance (1986) and ${ }^{14} \mathrm{C}$-dated at $5.2 \pm 0.1 \mathrm{ka}$. This resulted from a $0.07-\mathrm{km}^{3}$ avalanche that left the shelf now occupied by White Salmon Glacier. After rushing down Cascade and Salt Creeks and the upper White Salmon River gorge, the debris spread out to cover about $15 \mathrm{~km}^{2}$ of the Trout Lake lowland, impounding Trout Lake and continuing as an intracanyon tongue at least as far as Husum, some $60 \mathrm{~km}$ from its source. Clay-sized particles make up 3-8 weight percent of the "Trout Lake Mudflow" and comparable fractions of lesser Holocene deposits originating from the same altered headwall (Vallance, 1986). Persistence of poor sorting for great distances, and the matrix strength needed to transport 5-10 m megaclasts for tens of kilometers downstream, are properties characteristic of clay-rich cohesive debris flows that originate as avalanches or sector collapses of hydrothermally altered stratovolcanic edifices (Scott and others, 1992).

Avalanches of clay-rich summit debris will certainly recur in the future, but the attendant devastation (as in the case of lava flows and flood-initiated debris flows) would normally be limited to the flanks of the volcano and to the upper reaches of affected stream valleys. Radically more destructive events, like failure of the glacially undercut west peak (The Pinnacle) or a large-scale sector collapse of the main cone, are improbable even on a 1000-year timescale. Like the "Trout Lake Mudflow" of 5200 years ago, however, valley-confined debris flows resulting from huge avalanches could threaten downstream settlements as far as Husum and Klickitat, and perhaps even the reservoirs on the Lewis, Cowlitz-Cispus, and White Salmon Rivers, 50-70 km from the volcano. So catastrophic a collapse might require triggering by a major earthquake or by renewed magmatic intrusion of the main cone, events that are themselves of low probability in the Mount Adams region.

\section{RESOURCE ASSESSMENT}

\section{MINERAL RESOURCES}

Our previously published assessments of the mineral- and geothermal-resource potential of the Mount Adams area (Hildreth and others, 1983; Hildreth and Fierstein, 1990) are only reinforced by the additional data presented here. The Quaternary lavas are barren of mineralization, and the surrounding Tertiary rocks have been prospected for a century with little success (Moen, 1977, 1982).

The solfatarically altered summit is the only mineralized zone recognized at Mount Adams. Exposures on glacial headwalls and cleavers around the icecap indicate that much of the 4-km ${ }^{2}$ summit cone is fragmental andesite that has undergone severe acid-sulfate alteration. The conduit system by which magma repeatedly rose and erupted during thousands of years of summit activity remains today the permeable zone through which warm $\mathrm{H}_{2} \mathrm{~S}$-bearing vapors reach the surface. Near-surface oxidation of $\mathrm{H}_{2} \mathrm{~S}$ produces both elemental sulfur and sulfuric acid, which 
in turn leaches and reacts with the fragmental andesite, converting it to an assemblage dominated by kaolinite, alunite, gypsum, and silica. In 60 samples analyzed by $\mathrm{X}$-ray diffraction, sparse pyrite was the only sulfide identified, and elemental sulfur was far less abundant than sulfates, kaolinite, silica, and residual andesite (Hildreth and others, 1983). Fairly pure sulfur largely restricted to veins and vug fillings was reported by prospectors employed by the Glacier Mining Company, who dug several pits adjacent to the summit icecap in the 1930's (Hildreth and others, 1983). The sulfur claims were eventually abandoned, presumably because excavation beneath the icecap would entail formidable risks to life, limb, and capital. The summit and most of the stratocone are now inside the Mount Adams Wilderness, where no valid claims exist today.

Decorative stone for flagstones and facing has been quarried locally from platy-jointed andesitic lava flows. Several cinder cones in the map area have been quarried for road metal, but others contain large proportions of agglutinated spatter, which makes excavation troublesome. Road metal has also been obtained in the lowland periphery by quarrying and crushing basaltic lava flows and the rhyolite lava of Mann Butte (Trm), the lightcolored chips of which are notorious in the Trout Lake area for puncturing tires. Fluvially sorted sand, gravel, and boulders are locally accessible along the Klickitat, Cispus, Lewis, and White Salmon Rivers; on the other hand, most of the glacial deposits (gn, gy, go) are poorly sorted, rich in muddy matrix and scattered boulders, requiring laborious processing for most uses.

\section{GEOTHERMAL RESEARCH DRILLHOLES}

The Washington Division of Geology and Earth Resources has drilled numerous shallow geothermal-gradient test wells in the southern Washington Cascades (Schuster and others, 1978; Korosec and Schuster, 1981; Schuster and Korosec, 1981; Barnett, 1986; Barnett and Korosec, 1989), including several in the lowland periphery of Mount Adams (table 1). None is strictly within the volcanic field, but most of the holes listed in table 1 are within $10 \mathrm{~km}$ of it. Only holes 85-3 and 85-5 penetrated Quaternary basalt before entering Tertiary rocks. In all but one hole, the geothermal gradients were measured for intervals (table 1) within Tertiary volcanic or volcaniclastic sedimentary rocks generally rich in clays or zeolites and of fairly low permeability; hole 85-1c was in Tertiary quartz diorite. All gradients were measured below the zone of seasonal temperature influence (Barnett and Korosec, 1989). Shallow aquifers were intersected by holes $85-3,85-4,88-3$, and $88-5$, but only 88-5 appears to be strongly cooled by flowing groundwater. All but two (85-1c and DNR-9) of the holes listed in table 1 are within $5 \mathrm{~km}$ of Quaternary volcanic vents. Holes $85-2,85-4$, and $85-5$ are within $1 \mathrm{~km}$ of Quaternary basaltic vents, and hole 88 5 is $2 \mathrm{~km}$ from a 380 -ka dacite lava flow (and possibly its vent). None of the gradient or heat-flow data (table 1 ) is unusual for the southern Washington Cascades.

\section{SPRINGS AND FUMAROLES}

Annual precipitation probably exceeds $350 \mathrm{~cm}$ (140") on Mount Adams but declines eastward to only $85 \mathrm{~cm}$ (34") at Glenwood. Rainfall and snowmelt provide impressive runoff all year. On the stratocone and its lava-flow apron, we visited about 100 springs, none warmer than $6^{\circ} \mathrm{C}$ (on summer days). In the lowland periphery, numerous additional springs issue from Quaternary basalts, gravels and till, or from Tertiary volcanic rocks. Many such springs have been sampled by the U.S. Geological Survey (Cline, 1976) or by the Washington Division of Geology and Earth Resources; the data available for the greater Mount Adams region are summarized in table 2. Of 47 springs listed by Cline (1976) for the Klickitat River drainage (the north and east flanks of Mount Adams and part of the Simcoe Mountains volcanic field), 41 springs (including all the large ones) had orifice temperatures lower than $10^{\circ} \mathrm{C}$. The remaining 6 springs had temperatures of $10^{\circ}-23.8^{\circ} \mathrm{C}$, but all six had discharge rates lower than 25 liters/minute. Four slightly warm springs $\left(15^{\circ}-27^{\circ} \mathrm{C}\right)$ listed in table 1 all occur at notably low elevations on the walls of major drainages (the Klickitat and Cispus Rivers); 3 of the 4 have $\mathrm{Cl}$ concentrations elevated relative to other springs in the district. Another spring (Klickitat River weir spring) in the Klickitat River gorge also has elevated $\mathrm{Cl}$ but a temperature of only $12^{\circ} \mathrm{C}$ and low discharge. These few slightly warm springs all issue from Tertiary rocks or from the base of Quaternary basalts just above such Tertiary rocks.

Cline (1976) emphasized the vigorous movement of groundwater from recharge areas on Mount Adams to a major discharge zone about $15 \mathrm{~km}$ to the east, along the south-flowing Klickitat River. Along a $20-\mathrm{km}$ reach of the Klickitat River adjacent to the eastern apron of Mount Adams, more than 400 cubic feet per second (cfs) $(680,000 \mathrm{l} / \mathrm{min})$ of groundwater discharged into the river during the autumn of 1974 (autumn is a season of relatively low discharge). About half of this discharge was from a few large springs, of which Cascade Spring was most productive at $40 \mathrm{cfs}(68,000 \mathrm{l} / \mathrm{min})$. Most of the radial outflow of groundwater from Mount Adams takes place within the apron of Quaternary andesitic and basaltic lavas (and glacial deposits), rather than within the less permeable Tertiary rocks in which the thermal measurements were made.

Diffuse discharge of $\mathrm{H}_{2} \mathrm{~S}$-bearing vapor takes place through crevasses in the summit icecap of Mount Adams and perhaps from steep glacial headwalls of acid-sulfatealtered fragmental andesite adjacent to that icecap (Hildreth and others, 1983). Prospect pits (for sulfur) dug through the icecap in the 1930's encountered (or induced) a fumarole with a maximum temperature of $65^{\circ} \mathrm{C}$. No well-defined fumaroles were found during the 1980's, although an $\mathrm{H}_{2} \mathrm{~S}$ odor remains perceptible on and near the summit. Weak vapor discharge may be derived or recycled from still-warm Holocene conduits or, less likely, may reflect chimney-focussing of a small flux of gas from a deepcrustal zone of magma storage. 


\section{GEOTHERMAL RESOURCES}

A model of the thermal regimes associated with arc magmatism is implicit in previously published papers (Hildreth, 1981; Hildreth and Moorbath, 1988). It is argued that andesitic and basaltic magmas largely evolve in the deep crust or crust-mantle transition zone and that neither survives prolonged residence in the upper crust. Mafic magma that stalls in the upper $10-20 \mathrm{~km}$ of the crust fractionates rapidly to silicic magma and cumulate mush. (Most diorite-gabbro plutons in the upper crust represent such cumulates, not the bulk compositions of andesitic-to-basaltic magmas that were injected and stored at shallow levels.) Accordingly, magma reservoirs shallow enough (less than $10 \mathrm{~km}$ ?) to sustain high-temperature convecting geothermal systems should quickly develop silicic differentiates and could erupt either dacite or rhyolite, but not basalt or andesite-except as dispersed mixtures or cumulate dregs associated with silicic eruptive units. Conversely, in settings such as Mounts Adams, Rainier, Baker, McLoughlin, and much of central Oregon (south of Mount Hood to McKenzie Pass), the voluminous throughput of andesitic and varied basaltic magmas shows that there is little or no storage of low-density silicic magma in the mid-to-upper crust. There is no conflict between the sparsity of geothermal manifestations and the abundance of Quaternary andesitic-basaltic vents in the Cascades, if nearly all magma storage is $30-45 \mathrm{~km}$ deep. The moderate (50-100 milliwatts per $\left.\mathrm{m}^{2}\right)$ heat flow characteristic of the High Cascades seems consistent with distributed pockets of andesitic and basaltic magma near the base of the crust beneath the belt of late Quaternary arc volcanism. (The Simcoe, Newberry, Medicine Lake, and Lassen regions are magmatically and tectonically more complicated than straightforward arc volcanism).

A corollary of such a conceptual model is the irrelevance of eruption rates (per unit area, per unit arc-length, or per volcanic field) for geothermal resource potential. The late Quaternary eruption rate at Mount Adams is very large, but it was all mafic-to-intermediate magmatic throughput that resulted in little or no upper-crustal storage. Many large stratocones or major components of compound edifices can be constructed very rapidly-in 100's of years or a few 1000 years-without establishment of significant upper-crustal magma reservoirs. The nearby Columbia River Basalt Group is a still more spectacular example; eruption rates were enormous but, judging from the virtual lack of accompanying silicic magmas, midto-upper-crustal storage was trivial. What counts for geothermal resources is shallow magma storage, not throughput, and it is not at all clear that these are related.

Specifically, for Mount Adams the geothermal resource potential is considered low because: (1) There are virtually no silicic eruptive products younger than $100 \mathrm{ka}$. (2) Late Pleistocene and Holocene eruptive units along the elongate zone of vents are exclusively basaltic and andesitic; blind (unvented) silicic magma is not impossible, but it would have to have evolved in late Holocene time. (3) Neither the aeromagnetic nor gravity maps (Schuster and others, 1978; reviewed in Hildreth and others, 1983) provide any suggestion of magma storage. (4) High precipitation on the stratocone disperses and dissipates whatever heat may be supplied convectively from Holocene conduits to the fumarolically altered cone. (5) Springs are numerous but mostly cold. (6) The few slightly warm springs $\left(10^{\circ}-24^{\circ} \mathrm{C}\right)$ that emerge from poorly permeable Tertiary volcanic rocks in peripheral areas have low discharge. (7) Geothermal gradients in such Tertiary rocks are in the range $21^{\circ}-72^{\circ} \mathrm{C} / \mathrm{km}$, ten drillholes averaging about $50^{\circ} \mathrm{C} / \mathrm{km}$ (table 1 ); such gradients suggest that drilling in the lowland periphery of Mount Adams might yield water sufficiently warm and abundant for space heating or agricultural uses but almost certainly not hot enough for power production.

\section{ACKNOWLEDGMENTS}

We are grateful to Peggy Bruggman for trace-element determinations and for producing this map in its digital form using the GIS system ARC/INFO; to Marvin Lanphere for numerous high-precision $\mathrm{K}-\mathrm{Ar}$ ages; to the staff of the USGS laboratory supervised by Joseph Taggart in Lakewood, Colorado, for major-element determinations; and to Paul Hammond of Portland State University for advice in getting the project started. Hammond and Donald A. Swanson were the principal scientific reviewers of the geologic map and pamphlet. Christine Kelley ably processed repeated drafts of the text. The Yakima Tribal Council and the Mount Adams Ranger District of Gifford Pinchot National Forest permitted and facilitated access to parts of the volcanic field under their administration. We thank our many friends in Trout Lake and Glenwood for their interest, advice, and hospitality. In particular, Susan Hadley, Darryl Lloyd, Nancy Driscoll, Harold Cole, Don Tahkeal, Jack Thorne, Duane Webberley, Bonnie Henderson, Darvel Lloyd, George Strong, Ken Sheridan, Keith McCoy, Kate and Rusty Reed, Sally Wakefield, Bev and Greg Meyer, Gil and Millie Martin, John Hylton, Jerry Lorenz, Cora Lee and Don Warner, Gary Harding, Ann and Walt Campbell, Phil Zoller, and George Woodruff made significant geological or logistical contributions to the project. Gail Mahood and Rich Schouboe provided occasional field support on the mountain and a decade of morale support from afar. William $\mathrm{O}$. Douglas served longer on the Supreme Court of the United States than any other Justice in our nation's history, but he spent his summers in Glenwood where he could see the sunrise touch the summit of Mount Adams.

\section{REFERENCES CITED}

Anderson, J.L., 1987, Geologic map of the Klickitat 15' quadrangle, Washington: Washington Division of Geology and Earth Resources Open File Report 87-14, scale $1: 38,400$.

Barnes, I., Johnston, D.A., Evans, W.C., Presser, T.S., Mariner, R.H., and White, L.D., 1981, Properties of gases and waters of deep origin near Mount St. Helens: U.S. Geological Survey Professional Paper 1250, p. 233-237.

Barnett, D.B., 1986, The 1985 geothermal gradient drilling project for the State of Washington: Washington 
Division of Geology and Earth Resources Open-File Report 86-2, $36 \mathrm{p}$.

Barnett, D.B., and Korosec, M.A., 1989, Results of the 1988 geothermal gradient test drilling project for the State of Washington: Washington Division of Geology and Earth Resources Open-File Report 89-2, 54 p.

Beckey, F., 1974, Cascade alpine guide, climbing and high routes: v. 1 , Columbia River to Stevens Pass: Seattle, The Mountaineers, $354 \mathrm{p}$.

Byam, F.M., 1921, The Mount Adams slide of 1921: Mazama, v. 6, no. 2, p. 44-46.

Cline, D.R., 1976, Reconnaissance of the water resources of the upper Klickitat River basin, Yakima Indian Reservation, Washington: U.S. Geological Survey Open-File Report 75-518, 54 p.

Crandell, D.R., 1971, Postglacial lahars from Mount Rainier volcano, Washington: U.S. Geological Survey Professional Paper 677, $73 \mathrm{p}$.

Crandell, D.R., and Miller, R.D., 1974, Quaternary stratigraphy and extent of glaciation in the Mount Rainier region, Washington: U.S. Geological Survey Professional Paper 847, 59 p., 2 pl.

Ellingson, J.A., 1972, The rocks and structure of the White Pass area, Washington: Northwest Science, v. 46, p. 9-24.

Halliday, W.R., 1963, Caves of Washington: Washington Division of Mines and Geology, Information Circular no. 40, 132 p., 9 pl.

Hammond, P.E., 1980, Reconnaissance geologic map and cross sections of southern Washington Cascade Range: Portland State University, Department of Earth Sciences, 31 p., 2 sheets, scale 1:125,000.

Hammond, P.E., and Korosec, M.A., 1983, Geochemical analyses, age dates, and flow-volume estimates for Quaternary volcanic rocks, southern Cascade Mountains, Washington: Washington Division of Geology and Earth Resources Open-File Report 88-13, $36 \mathrm{p} ., 1 \mathrm{pl}$.

Hammond, P.E., Pedersen, S.A., Hopkins, K.D., Aiken, D., Harle, D.S., Danes, Z.F., Konicek, D.L., and Stricklin, C.R., 1976, Geology and gravimetry of the Quaternary basaltic volcanic field, southern Cascade Range, Washington, in Pezzotti, C., ed., Proceedings of the Second U.N. Symposium on the Development and Use of Geothermal Resources, San Francisco, May 20-29, 1975: v. 1, p. 397-405.

Hildreth, W., 1981, Gradients in silicic magma chambers: Implications for lithospheric magmatism: Journal of Geophysical Research, v. 86, p. 10153-10192.

Hildreth, W., and Fierstein, J., 1990, Geologic map and geothermal assessment of the Mount Adams volcanic field, Cascade Range of southern Washington: Geothermal Resources Council Transactions, v. 14, p. 1455-1456.

Hildreth, W., Fierstein, J., and Miller, M.S., 1983, Mineral and geothermal resource potential of the Mount Adams Wilderness and contiguous roadless areas, Skamania and Yakima Counties, Washington: U.S. Geological Survey Open-File Report 83-474, 49 p.

Hildreth, W., and Lanphere, M.A., 1994, Potassium-argon geochronology of a basalt-andesite-dacite arc system: The Mount Adams volcanic field, Cascade Range of southern Washington: Geological Society of America Bulletin, v. 106, p. 1413-1429

Hildreth, W., and Moorbath, S., 1988, Crustal contributions to arc magmatism in the Andes of central Chile: Contributions to Mineralogy and Petrology, v. 98 , p. $455-489$.

Hopkins, K.D., 1976, Geology of the south and east slopes of Mount Adams volcano, Cascade Range, Washington: Ph.D. thesis, University of Washington, Seattle, 143 p., 1 pl.

Jones, F.O., 1960, White Salmon River Project, Engineering Planning Report, Volume II, Geology and Foundation Explorations: Unpublished report prepared by North Pacific Consultants for Klickitat County Public Utility District No. 1, State of Washington, $216 \mathrm{p}$.

Korosec, M.A., 1989, New K-Ar age dates, geochemistry, and stratigraphic data for the Indian Heaven Quaternary volcanic field, south Cascade Range, Washington: Washington Division of Geology and Earth Resources Open-File Report 89-3, 42 p.

Korosec, M.A., and Schuster, J.E., 1981, The 19791980 geothermal resource assessment program in Washington: Washington Division of Geology and Earth Resources Open-File Report 81-3, 270 p., 1 pl., scale 1:24:000.

Leeman, W.P., Smith, D.R., Hildreth, W., Palacz, Z., and Rogers, N., 1990, Compositional diversity of Late Cenozoic basalts in a transect across the southern Washington Cascades: Implications for subduction zone magmatism: Journal of Geophysical Research, v. 95, p. 19561-19582.

Luedke, R.G., Smith, R.L., and Russell-Robinson, S.L., 1983, Map showing distribution, composition, and age of Late Cenozoic volcanoes and volcanic rocks of the Cascade Range and vicinity, northwestem United States: U.S. Geological Survey Map I-1507.

Mahaney, W.C., Fahey, B.D., and Lloyd, D.T., 1981, Late Quaternary glacial deposits, soils, and chronology, Hellroaring Valley, Mount Adams, Cascade Range, Washington: Arctic and Alpine Research, v. 13, p. 339-356.

Miller, R.B., 1989, The Mesozoic Rimrock Lake inlier, southem Washington Cascades: Implications for the basement to the Columbia Embayment: Geological Society of America Bulletin, v. 101, p. 1289-1305.

Moen, W.S., 1977, St. Helens and Washougal mining districts of the southern Cascades of Washington: Washington Division of Geology and Earth Resources Information Circular 60, $71 \mathrm{p}$.

Moen, W.S., 1982, The mineral industry of Washington-highlights of its development, 1853-1980: Washington Division of Geology and Earth Resources Information Circular 74, $26 \mathrm{p}$.

Mooney, W.D., and Weaver, C.S., 1989, Regional crustal structure and tectonics of Pacific coastal states; California, Oregon, and Washington: Geological Society of America Memoir 172, p. 129-161.

Mullineaux, D.M., 1986, Summary of pre-1980 tephrafall deposits erupted from Mount St. Helens, Washington state, U.S.A.: Bulletin of Volcanology, v. 48 , p. $17-26$. 
Norris, R.D., 1991, The Cascades volcanoes: Monitoring history and current land management: U.S. Geological Survey Open-File Report 91-31, 68 p.

Richardson, D., 1968, Glacier outburst floods in the Pacific Northwest: U.S. Geological Survey Professional Paper 600-D, p. D79-D86.

Richmond, G.M., and Fullerton, D.S., 1985. Introduction to Quaternary glaciations in the United States of America: Quaternary Science Reviews, v. 5, p. 3-10.

Savage, J.C., and Lisowski, M., 1991, Strain measurements and the potential for a great subduction earthquake off the coast of Washington: Science, v. 252, p. 101-103.

Schuster, J.E., Blackwell, D.D., Hammond, P.E., Huntting, M.T., 1978, Heat flow studies in the Steamboat Mountain-Lemei Rock Area, Skamania County, Washington: Washington Division of Geology and Earth Resources Information Circular 62, 56 p.

Schuster, J.E., and Korosec, M.A., 1981, Preliminary report on heat-flow drilling in Washington during 1981: Washington Division of Geology and Earth Resources Open-File Report 81-8, 36 p.

Scott, K.M., Pringle, P.T., and Vallance, J.W., 1992, Sedimentology, behavior, and hazards of debris flows at Mount Rainier, Washington: U.S. Geological Survey Open-File Report 90-385, $106 \mathrm{p}$.

Sheppard, R.A., 1967a, Geology of the Simcoe Mountains volcanic area, Washington: Washington Division of Mines and Geology Geological Map Series GM-3; scale 1:250,000.

Sheppard, R.A., 1967b, Petrology of a late Quaternary potassium-rich andesite flow from Mount Adams, Washington: U.S. Geological Survey Professional Paper 575-C, p. C55-C59.
Smith, J.G., 1993, Geologic map of upper Eocene to Holocene volcanic and related rocks in the Cascade Range, Washington: U.S. Geological Survey Map I-2005; scale 1:500,000; pamphlet $19 \mathrm{p}$.

Stanley, W.D., Finn, C., and Plesha, J.L., 1987, Tectonics and conductivity structures in the southern Washington Cascades: Journal of Geophysical Research, v. 92, p. 10179-10193.

Swanson, D.A., and Clayton, G.A., 1983, Generalized geologic map of the Goat Rocks Wilderness and adjacent roadless areas, Lewis and Yakima Counties, Washington: U.S. Geological Survey Open-File Report 83-357; scale 1:48,000, pamphlet $10 \mathrm{p}$.

Uto, K., Hildreth, W., and Lanphere, M.A., 1991, Geology, geochemistry, and geochronology of the southern half of the Simcoe Mountains volcanic field, Washington: Eos, Transactions American Geophysical Union, v. 72 , p. 521.

Vallance, J.W., 1986, Late Quaternary volcanic stratigraphy on the southwestern flank of Mount Adams volcano, Washington: M.S. thesis, University of Colorado, Boulder, $122 \mathrm{p}$.

Walsh, T.J., Korosec, M.A., Phillips, W.M., Logan, R.L., and Schasse, H.W., 1987, Geologic Map of Washington-southwest quadrant: Washington Division of Geology and Earth Resources, Geologic Map GM34, 28 p., 2 sheets, scale 1:250,000.

Weaver, C.S., and Baker, G.E., 1988, Geometry of the Juan de Fuca plate beneath Washington and northern Oregon from seismicity: Bulletin of the Seismological Society of America, v. 78, p. 264-275.

Zoback, M.L., 1990, Intraplate stress and deformation: National Earthquake Hazards Reduction Program, Summaries of Technical Reports: U.S. Geological Survey Open-File Report 90-334, p. 537-540 


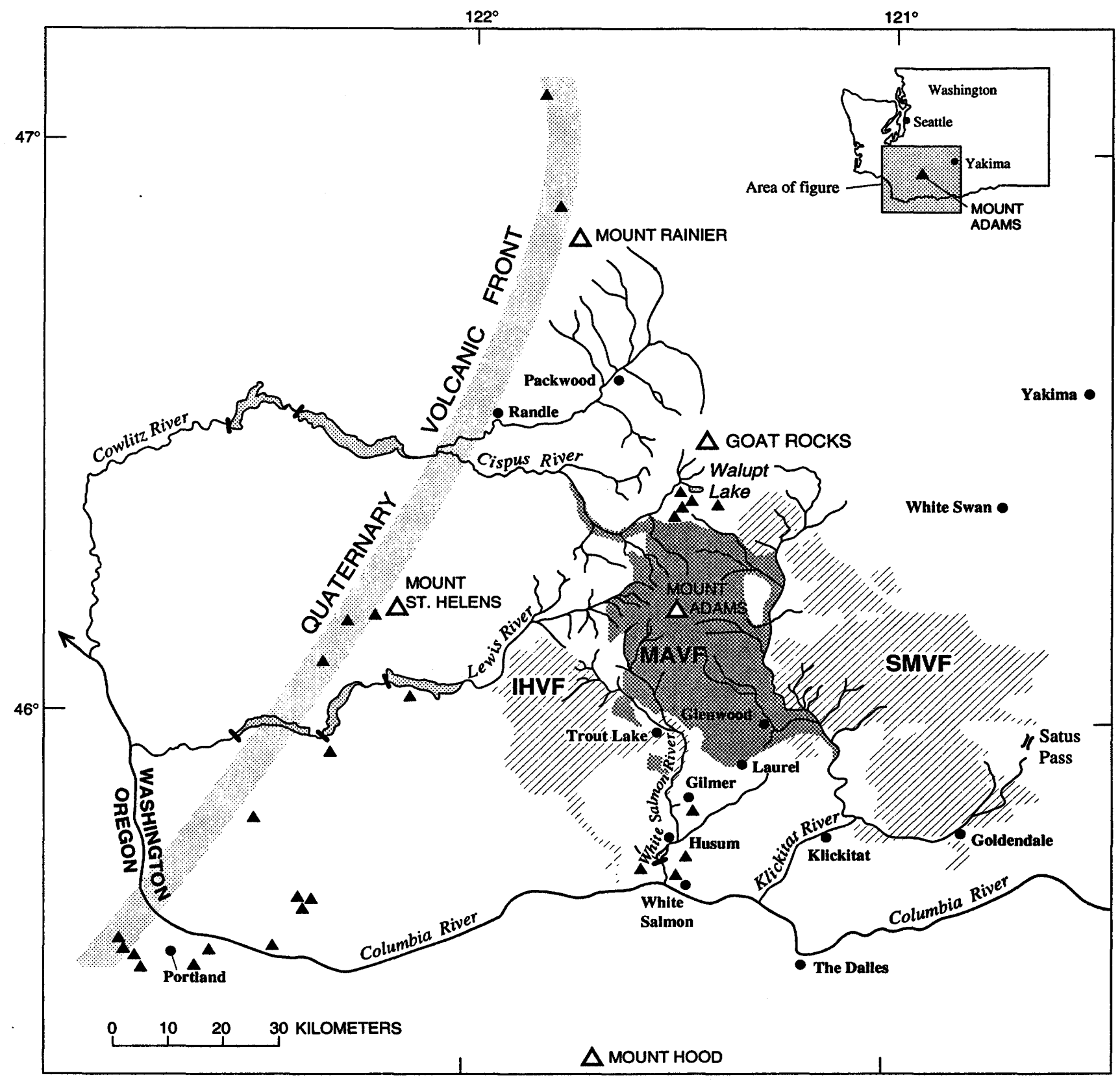

Figure 1. Regional location map showing distribution of Mount Adams (MAVF), Indian Heaven (IHVF), and Simcoe Mountains (SMVF) volcanic fields and emphasizing four river systems that drain Mount Adams. Symbols: dot, selected towns; open triangle, large stratovolcanoes; small filled triangles, selected lesser volcanic centers, including a few mentioned in the text north and south of Mount Adams volcanic field and several more that help define the Quaternary volcanic front of southwest Washington. Shaded pattern with dark bar indicates dam-impounded reservoirs. 


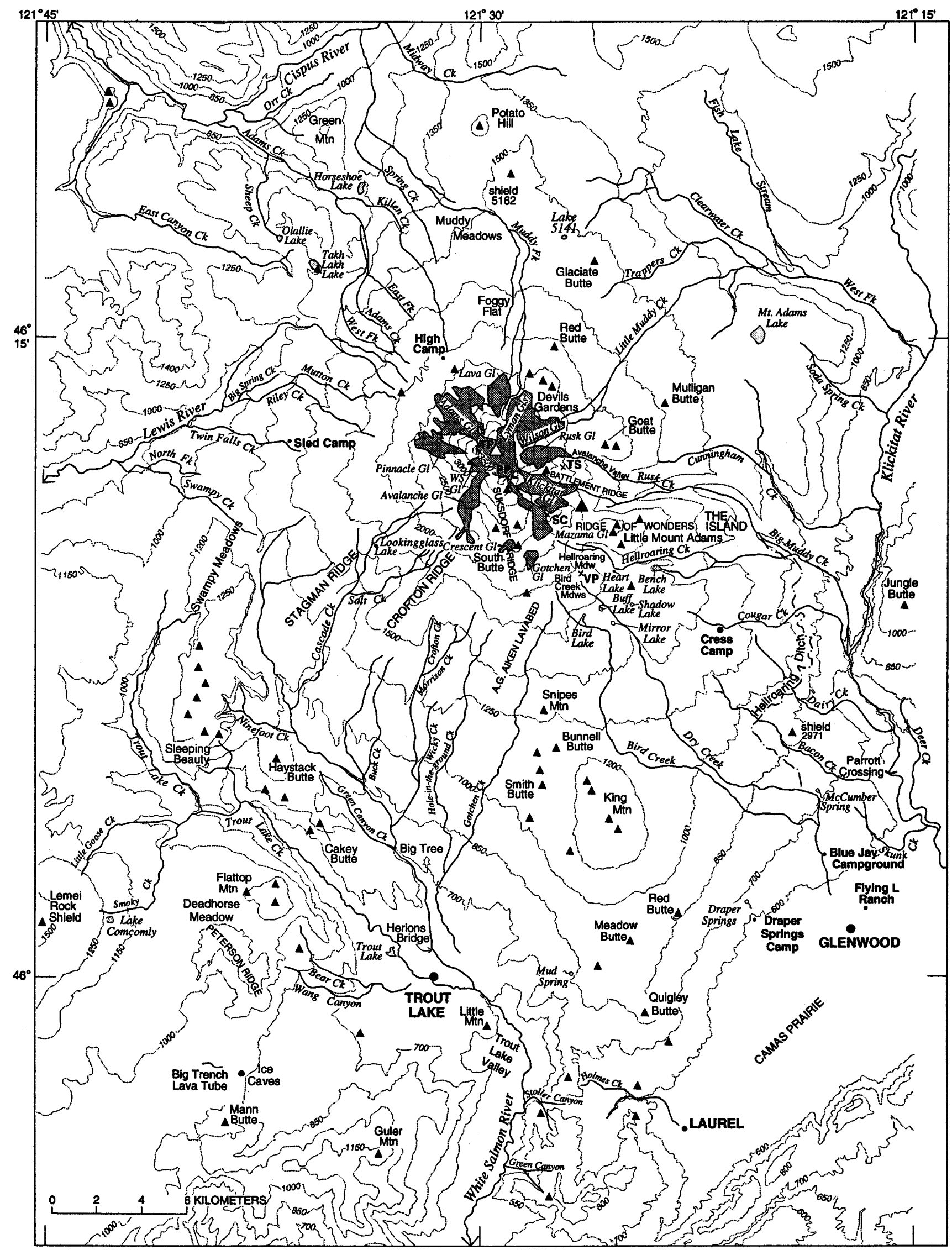

Figure 2. Location map for area covered by geologic map, emphasizing drainages and place names referred to in text and Description of Map Units. Abbreviations: PP, Pikers Peak (south summit); TP, The Pinnacle (west summit); TS, The Spearhead; VP, Hellroaring Viewpoint; SC, Sunrise Camp; Ck, Creek; Fk, Fork.; $\triangle$, Summit of Mount Adams; $\Delta$, other eruptive vents exposed; $\Delta$, approximate center of 500 -ka Hellroaring Volcano. 
Table 1. Geothermal gradient drillholes near Mount Adams

\begin{tabular}{|c|c|c|c|c|c|c|c|c|c|}
\hline \multirow{2}{*}{ Hole No. } & \multirow{2}{*}{ Location name } & \multicolumn{2}{|c|}{ From Adams summit } & \multirow{2}{*}{ Depth (m) } & \multirow{2}{*}{$\begin{array}{c}\text { Bottom-hole } \\
\text { temperature } \\
\left({ }^{\circ} \mathrm{C}\right)\end{array}$} & \multicolumn{2}{|c|}{ Gradient } & \multirow{2}{*}{$\begin{array}{l}\text { Estimated heat flow in } \\
\text { milliwatts per } \mathrm{m}^{2}\end{array}$} & \multirow{2}{*}{ Ref } \\
\hline & & $\mathrm{km}$ & Azimuth & & & $\mathrm{C} / \mathrm{km}$ & interval $(\mathrm{m})$ & & \\
\hline DNR 88-3 & Chambers Creek & 23.9 & $349^{\circ}$ & 152.3 & 13.3 & 58.9 & $45.0-152.3$ & $127-145$ & 4 \\
\hline DNR 88-5 & Babyshoe Ridge & 12.0 & $307^{\circ}$ & 152.6 & 5.1 & $\sim 2.8$ & $35.0-152.6$ & - & 4 \\
\hline DNR 88-6 & Pin Creek & 17.0 & $278^{\circ}$ & 152.5 & 11.8 & 49.7 & $35.0-152.5$ & $75-85$ & 4 \\
\hline DNR 85-1c & Orr Creek & 17.8 & $333^{\circ}$ & 305 & 17.7 & 56 & $150-305$ & $112-168$ & 3 \\
\hline DNR 85-2 & Spud Hill & 22.0 & $315^{\circ}$ & 152 & 16.3 & 72 & $25-149$ & $100-130$ & 3 \\
\hline DNR 85-3 & Midway & 17.0 & $350^{\circ}$ & 110 & 7.1 & 33 & 15-109 & $46-59$ & 3 \\
\hline DNR 85-4 & $\begin{array}{l}\text { Mount Adams SE. } \\
\text { (Dairy Creek) }\end{array}$ & 17.2 & $130^{\circ}$ & 144 & 12.5 & 45 & $30-142$ & $63-72$ & 3 \\
\hline DNR 85-5 & Bear Spring & 21.5 & $203^{\circ}$ & 152 & 7.5 & 21 & $60-150$ & $29-38$ & 3 \\
\hline DGER-2 & Stadleman Swamp & 26.2 & $201^{\circ}$ & 153.1 & 12.2 & 52.7 & $100-150$ & $\sim 75$ & 1 \\
\hline DGER-3 & Mosquito Creek & 20.0 & $234^{\circ}$ & 152.5 & 13.0 & 58.5 & $115-150$ & $\sim 66$ & 1 \\
\hline DNR-9 & Klickitat & 44.7 & $140^{\circ}$ & 119.8 & 20.1 & 51.0 & $75-110$ & - & 2 \\
\hline
\end{tabular}

References: 1. Schuster and others (1978)

2. Schuster and Korosec (1981)

3. Barnett (1986)

4. Barnett and Korosec (1989) 
Table 2. Springs near Mount Adams

\begin{tabular}{|c|c|c|c|c|c|c|c|c|c|c|c|c|c|}
\hline \multirow{2}{*}{ Location } & \multicolumn{2}{|c|}{ From Adams Summit } & \multirow{2}{*}{$\begin{array}{c}\text { Temperature } \\
\left({ }^{\circ} \mathrm{C}\right)\end{array}$} & \multirow{2}{*}{ Flow $(1 / \mathrm{min})$} & \multicolumn{8}{|c|}{ Water analysis (parts per million) } & \multirow{2}{*}{ Ref. } \\
\hline & $\mathrm{km}$ & Azimuth & & & $\mathrm{HCO}_{3}$ & $\mathrm{SO}_{4}$ & $\mathrm{Cl}$ & $\mathrm{Na}$ & $\mathbf{K}$ & $\mathrm{Ca}$ & $\mathrm{Mg}$ & $\mathrm{SiO}_{2}$ & \\
\hline Bacon Creek Springs & 13.3 & $135^{\circ}$ & 6 & - & - & - & 1 & 5.9 & 1.2 & 0.7 & - & 17 & 1 \\
\hline Bear Creek Spring & 21.5 & $203^{\circ}$ & 13 & - & - & - & 1 & 5.4 & 0.6 & 1.7 & - & 24 & 1 \\
\hline Gotchen Creek Spring & 12.7 & $178^{\circ}$ & 3 & - & - & - & 1 & 3.4 & 1.5 & 0.4 & - & 17 & 1 \\
\hline Orr Creek Warm Springs & 17.8 & $333^{\circ}$ & 21.7 & $75-115$ & - & 1 & 28 & 29 & 9 & 3 & 0.1 & 29 & 2 \\
\hline Soda Spring Campground (upper) & 16.8 & $79^{\circ}$ & 6 & $\sim 20$ & 39 & 1.8 & 0.9 & 3.6 & 0.9 & 5.5 & 2.4 & - & 3 \\
\hline Soda Spring Campground (lower) & 17.2 & $85^{\circ}$ & 10.2 & 11 & - & - & - & - & - & - & - & - & 3 \\
\hline Fish Hatchery Warm Spring & 30.2 & $128^{\circ}$ & 23.8 & $\sim 15$ & 1130 & 2.6 & 49 & 160 & 16 & 110 & 95 & - & 3 \\
\hline Klickitat Mineral Springs & 50.8 & $145^{\circ}$ & 27 & - & 1070 & 2 & 4.2 & 64 & 10 & 120 & 100 & 140 & 2,4 \\
\hline Klickitat Soda Springs & 45.0 & $139^{\circ}$ & $15-17$ & $\cdot$ & $\cdot$ & - & - & $\cdot$ & - & $\cdot$ & - & - & 2 \\
\hline McCumber Spring & 20.5 & $135^{\circ}$ & 5.6 & 6800 & 26 & 0.9 & 0.2 & 2.9 & 1.5 & 4.3 & 1.6 & $\cdot$ & 3 \\
\hline Bup Spring & 15.5 & $97^{\circ}$ & 5 & $30-50$ & 36 & 0.9 & 0.8 & 3.0 & 0.7 & 5.3 & 2.2 & - & 3 \\
\hline Big Muddy Bridge Spring & 16.7 & $111^{\circ}$ & 6.3 & $\sim 500$ & 38 & 0.3 & 0.5 & 2.8 & 2.4 & 5.7 & 1.1 & - & 3 \\
\hline Trappers Creek Spring & 11.1 & $40^{\circ}$ & 3.3 & $\sim 11000$ & - & - & - & - & - & - & - & - & 3 \\
\hline Klickitat River Weir Spring & 20.2 & $74^{\circ}$ & 12.2 & $\sim 8$ & 951 & 2.2 & 92 & 150 & 16 & 97 & 86 & - & 3 \\
\hline Potato Hill Spring & 14.7 & $0^{*}$ & 2.9 & $\sim 20$ & 10 & 1.5 & 0.7 & 0.8 & 0.6 & 2.1 & 0.6 & $\cdot$ & 3 \\
\hline Wonder Spring & 31.0 & $127^{\circ}$ & 9.1 & $22000-38000$ & 59 & 1.1 & 0.2 & 4.2 & 1.1 & 8.9 & 4.5 & $\cdot$ & 3 \\
\hline Cascade Springs & 33.0 & $129^{\circ}$ & 8 & 85000 & 45 & 1.3 & 1.1 & 4 & 2.1 & $5-12$ & 3 & - & 3 \\
\hline Draper Springs & 27.7 & $150^{\circ}$ & 7.4 & $\sim 225$ & 33 & 0.1 & 0.5 & 2.6 & 1.9 & 4.2 & 2.2 & - & 3 \\
\hline Willard Spring & 25.8 & $155^{\circ}$ & 6.8 & $\sim 1500$ & 30 & 0.1 & 0.5 & 2.8 & 1.9 & 3.6 & 2.5 & - & 3 \\
\hline Cold Springs Ditch (Conboy HQ) & 29.0 & $157^{\circ}$ & 7 & $180-550$ & 38 & 1.1 & 0.3 & 3.4 & 2.5 & 4.5 & 3.0 & - & 3 \\
\hline Whitcomb Cabin Spring & 32.3 & $166^{\circ}$ & 9.5 & $10-20$ & 95 & 1.4 & 1.5 & 6.1 & 2.1 & 15 & 7.4 & - & 3 \\
\hline \multicolumn{14}{|l|}{ Rivers } \\
\hline Trout Lake Creek & - & - & 12 & - & - & - & 1 & 4.4 & 0.7 & 1.4 & - & 17 & 1 \\
\hline White Salmon River & - & - & 8 & - & - & - & 2 & 4.2 & 1.7 & 1.3 & - & 32 & 1 \\
\hline Klickitat Rur below Soda Springs Crk & - & - & - & - & 32 & 2.4 & 1.1 & 3.1 & 1.2 & 5.1 & 2.0 & - & 3 \\
\hline Klickitat River near Dead Canyon & - & - & - & - & 38 & 1.8 & 1.0 & 5.0 & 1.3 & 4.8 & 2.4 & - & 3 \\
\hline Big Muddy Creek & - & - & - & - & 22 & 7.2 & 0.8 & 3.0 & 1.5 & 4.1 & 1.8 & - & 3 \\
\hline Outlet Creek (above Falls) & - & - & - & - & 30 & 2.1 & 0.8 & 2.7 & 0.9 & 3.9 & 2.2 & - & 3 \\
\hline
\end{tabular}

References: 1. Schuster and others (1978)

2. Korosec and Schuster (1981)

3. Cline (1976)

4. Barnes and others (1981) 


\section{DESCRIPTION OF MAP UNITS INTRODUCTION}

The geologic map represents a Quaternary volcanic field active for approximately the past 900,000 years (900 ka). As the mapping was undertaken to establish the eruptive history and the attendant volcanic hazards and geothermal-resource potential of the volcanic field, pre-Quaternary rocks were largely ignored and (except for 4 silicic eruptive units) are here lumped as Tertiary basement (unit Tvs). No pre-Tertiary rocks crop out within or near the map area. Somewhat more (but still limited) attention was devoted to surficial deposits, because they widely obscure and locally intercalate with the Quaternary volcanic units.

Nearly all of the 136 volcanic map units described herein are newly defined. Each is an eruptive unit in the sense of derivation from a single vent or fissure. Some are simple flow units, but most are shields, cones, and stacks of lava flows that have chemical and mineralogical coherence. Each unit was delineated by field mapping, and its integrity confirmed or challenged by microscopic and chemical work in the laboratory; final definition of some units required iterative acquisition of field and laboratory data over a period of several years, providing a firm basis for subdividing or lumping somewhat heterogeneous groups of lavas. Most units have narrow compositional ranges, but some show zoning or heterogeneity extending across ranges of 1-4 percent $\mathrm{SiO}_{2}$. The varied products of a few long-lived eruptive centers (units ahv, app, aws) could no doubt be further subdivided by larger-scale mapping.

$\mathrm{SiO}_{2}$ contents given in the description of each volcanic unit are normalized on an anhydrous basis and rounded to the nearest 0.5 weight percent (\%); determinations were by $\mathrm{x}$-ray fluorescence methods in the U.S. Geological Survey laboratory at Lakewood, Colorado, supervised by J.E. Taggart. Major- and trace-element data will be published elsewhere.

Phenocryst contents (defined as crystals larger than $0.5 \mathrm{~mm}$ ) were estimated using a petrographic microscope and point-counting 1300-2000 points on each of 1-5 thin sections for each map unit. Abbreviations include: $\mathrm{cpx}$, clinopyroxene; opx, orthopyroxene; plag, plagioclase feldspar.

Ages are given for all volcanic units on the basis of mutual stratigraphic positions, 74 new potassium-argon (K-Ar) age determinations, a few radiocarbon $\left({ }^{14} \mathrm{C}\right)$ ages, and relations to glacial deposits and erosion. Following Richmond and Fullerton (1985), the Pleistocene age boundaries are taken to be $1.65 \mathrm{Ma}$ and $10 \mathrm{ka}$, and the boundaries between early, middle, and late Pleistocene are $788 \mathrm{ka}$ and $132 \mathrm{ka}$. Radiometric age determinations were undertaken in U.S. Geological Survey laboratories at Menlo Park, California; the ${ }^{14} \mathrm{C}$ ages were provided by $\mathrm{D}$. Trimble and the $\mathrm{K}$-Ar ages were obtained under the supervision of M.A. Lanphere (Hildreth and Lanphere, 1994).

\section{SURFICIAL DEPOSITS}

Glacial ice (Holocene)-Present-day glaciers and summit icecap. Many contacts with ice-cored

till and perennial snowbanks are only approximate

Is

daf

Debris-avalanche and debris-flow deposits

(Holocene)-Unconsolidated, poorly sorted sheets of andesitic rubble resulting from failure of glacially oversteepened, upper walls of Mount Adams. Major deposits below Adams, Avalanche, and Lyman Glaciers are older than Neoglacial moraines, but many small sheets of similar debris are younger-including sheets that came down Avalanche Glacier in 1921 and 1983. Small collapses over Rusk and Klickitat Glaciers are also common, but most such debris there is reworked as till and alluvium. Individual sheets contain clasts of all sizes in a matrix rich in silt and clay derived from the fumarolically altered summit mass; some emplacement units are internally graded. Many intact blocks are greater than $5 \mathrm{~m}$ across, some larger than $15 \mathrm{~m}$; blocks consist of breccia and stratified ejecta (of units app and aas), commonly cemented by silica and sulfates and typically yellow, white, orange-brown, or rusty ochre owing to solfataric alteration on the summit. Sheets extensive enough to funnel into stream valleys transform into water-rich debris flows that can extend many kilometers downstream; resulting deposits are lumped here with alluvium (yal), except for the exceptionally voluminous "Trout Lake Mudflow", which was ${ }^{14} \mathrm{C}$-dated at $5.2 \pm 0.1 \mathrm{ka}$ (Vallance, 1986). This deposit resulted from the large avalanche $\left(0.07 \mathrm{~km}^{3}\right)$ that left the shelf now occupied by White Salmon Glacier; after rushing down Cascade and Salt Creeks and the upper White Salmon River gorge, the debris spread out to cover about $15 \mathrm{~km}^{2}$ of Trout Lake Valley, impounding Trout Lake and continuing as an intracanyon tongue as far as Husum, some $60 \mathrm{~km}$ from its source. After farmers cleared thousands of blocks of summit-derived breccia, pastures of Trout Lake Valley were ploughed on this unit. Riverbank exposures are no thicker than $4 \mathrm{~m}$, but drilling showed the deposit to be locally as thick as $20 \mathrm{~m}$ about $1 \mathrm{~km}$ east-northeast of the lake (Jones, 1960)

Rock glaciers (Holocene)-Tongues of coarse blocky andesitic debris with interstitial or buried ice, undergoing slow downslope movement. All are adjacent to sources of abundant coarse debris, including steep rubbly cliffs, Neoglacial moraines, and margins of active glaciers. Transverse arcuate furrows, convex downstream, 
characterize surfaces. Although transitional in behavior to rock glaciers, ice-cored moraines, apparently stagnant at snouts of several active glaciers, are not included here

Neoglacial deposits (Holocene)-Neoglacial till (younger than $5 \mathrm{ka}$ ) and minor associated outwash. (Most outwash is mapped with unit yal.) Many steep, sharp-crested moraines date only from the last few centuries and largely remain barren (Hopkins, 1976; Mahaney and others, 1981)

gy Younger glacial deposits (late Pleistocene)Till and subordinate outwash emplaced during major glacial episode of 25-11 ka. Many discontinuous deposits and veneers are omitted. Till of this age is fresh, gray, and seldom oxidized to a depth greater than $0.5-1.5 \mathrm{~m}$. Weathering rinds on stones are absent or only incipient; 65-95 percent of stones in the till are pyroxene andesite, reflecting dominance of the high cone of Mount Adams (then in a period of active construction) as a debris source. Numerous steep moraines on all flanks of Mount Adams (probably dating principally from 21-14 ka) are heavily forested and mantled with immature loess-rich soil. Additional glaciers originating in Indian Heaven volcanic field supplied basalt-dominated glacial drift to southwest margin of map area. Deposits of this glacial episode are approximately ageequivalent to Evans Creek Drift at Mount Rainier (Crandell and Miller, 1974); they overlie several young volcanic units that were radiometrically dated, including units blc (29 ka), bic (22 ka), abs ( $28 \pm 6 \mathrm{ka})$, bsc (21 ka), app $(13 \pm 8 \mathrm{ka})$, ask (10 $\pm 16 \mathrm{ka})$, asb $(12 \pm 17 \mathrm{ka})$, and many other older lavas. [Area mapped as unit gy south of Avalanche Valley may contain some deposits of Neoglacial age] tocene)-Till and subordinate outwash emplaced during two or more major glacial advances older than the youngest $(25-11 \mathrm{ka})$ Pleistocene episode. Few constructional landforms survive; deposits are dissected morainal remnants and thin ground-moraine veneers (widely omitted from map), heavily forested and mantled with loess-rich soil. Till oxidized to depths of $2-5 \mathrm{~m}$; rinds on stones commonly 1-2 mm thick. These older deposits are recognized principally in southwest lowland part of map area; if once also present at middle elevations on Mount Adams, they have been covered, remobilized, obliterated, or overlooked. Glaciers flowed from at least two source areas, the Indian Heaven highland and the present site of Mount Adams. Only 9-40 percent of stones in till are pyroxene-andesite; predominance of basaltic and Tertiary lithologies shows that Mount Adams was not then a towering stratocone dominating the supply of ice and debris as during late

Wisconsin deposition of unit gy. Drift near confluence of Big Muddy Creek and Klickitat River (Hopkins, 1976) also predates unit gy and is probably coeval with the old drift in southwest sector of map. Among the youngest dated units overlain by this unit are: bew $(329 \pm 50 \mathrm{ka})$; uppermost part of aws ( $320 \pm 7 \mathrm{ka}) ;$ bcb $(246 \pm 19 \mathrm{ka})$; bhb $(209 \pm 21 \mathrm{ka}) ;$ apc $(120 \pm 5 \mathrm{ka}) ;$ and dcc $(117 \pm 6 \mathrm{ka})$. Probably largely equivalent to Hayden Creek Drift in the Mount Rainier area (Crandell and Miller, 1974), but a few remnants may be older. Lens of unit go about $15 \mathrm{~m}$ thick, exposed on north wall of Riley Creek at 4100', rests on Tvs and underlies units arc and dir $(252 \pm 8 \mathrm{ka})$

yal Younger alluvium (Holocene and late Pleistocene)-Unconsolidated, water-transported mud, sand, gravel, and coarser debris deposited in or adjacent to present-day streams, lakes, and swamps. Maximum known thickness $45 \mathrm{~m}$ (including $10-\mathrm{m}$ intercalated lava flow of unit bic) at Trout Lake (Jones, 1960); generally much thinner

oal Older alluvium (late and middle Pleistocene)Unconsolidated, river-transported deposits stranded high above present drainages. Characterized by well-rounded cobbles and boulders, many derived outside map area; subordinate mud, sand, and gravel are intercalated locally. Deposits $90-120 \mathrm{~m}$ above Klickitat River may have resulted from temporary damming of river by intracanyon lavas (bwf, apc, and bgb). Alluvial veneers atop unit bwf are more extensive than mapped; $3-10 \mathrm{~m}$ of that alluvium is locally sandwiched between units bwf and bgb. Deposit at Skunk Creek includes poorly rounded blocks of unit apc. Deposit at 2900' $(900 \mathrm{~m})$ on Bacon Creek contains cobbles of unit dhd but, being poor in andesite clasts, probably predates late Pleistocene glaciation (see unit gy)

s Surficial deposits, undivided (Holocene and late Pleistocene)-Generally a combination of debris-flow, fluvial, and glacial deposits. Locally includes combinations of till and talus

\section{VOLCANIC ROCKS}

(Listed alphabetically by 3-letter unit symbol)

aaa

Andesite of A.G. Aiken Lava Bed (Holocene)Plagioclase-rich pyroxene-andesite $\left(59 \% \mathrm{SiO}_{2}\right)$ lava flow, $20-70 \mathrm{~m}$ thick, from effusive fissure vent cutting lower southeast flank of South Butte (unrelated); near-vent scoria sparse. Phenocrysts: $20 \%$ plag (1-4 mm); $1-3 \%$ each opx and $\mathrm{cpx}(0.5-1.5 \mathrm{~mm})$; sparse $\mathrm{Fe}-\mathrm{Ti}$ oxides and olivine (to $1 \mathrm{~mm}$ ). Flow may be slightly zoned, the distal part having marginally greater $\mathrm{SiO}_{2}$ and little or no olivine. This uneroded, vitrophyric to scoriaceous, $7-\mathrm{km}$-long blocky flow is one of youngest eruptive units at Mount 
Adams; its age is between those of regional ashfall layers with ${ }^{14} \mathrm{C}$ ages of $6.8 \mathrm{ka}$ (Mazama ash) and $3.5 \mathrm{ka}$ (St. Helens Ye)

Andesite of Mount Adams Highway (early Pleistocene)-Phenocryst-poor high-K olivine-andesite $\left(54-54.5 \% \mathrm{SiO}_{2}\right)$ lava flows forming a pair of high benches near Dairy and Bacon Creeks, on west wall of Klickitat River. Banked against an older wall of Columbia River Basalt Group lavas that enclosed an earlier Klickitat drainage. Bench surfaces are $160-200 \mathrm{~m}$ above present river; base of unit is $120 \mathrm{~m}$ above the Klickitat at Dairy Creek but less than $85 \mathrm{~m}$ above it at Bacon Creek. Vent is concealed, probably beneath shield 2971, source of slightly younger unit abc $(903 \pm 13 \mathrm{ka})$. Best exposed on northeast-facing cliffs, where maximum thickness is $90 \mathrm{~m}$. Surfaces are vesicular, deeply weathered, and covered by loess-rich colluvium containing rounded corestones. Phenocrysts: $0.5 \%$ olivine $(0.5-1 \mathrm{~mm}) ; 3-5 \%$ plag (0.5-2 mm, rarely $3 \mathrm{~mm})$. Weathering emphasizes abundant white groundmass plag. Older than contiguous units adc, abc, bof, and bms; contact relation with bgo uncertain. K-Ar ages: $942 \pm 11 \mathrm{ka}$; $931 \pm 14 \mathrm{ka}$

Andesite of Mount Adams summit (late Pleistocene-Olivine-poor pyroxene-andesite (60.5-62\% $\mathrm{SiO}_{2}$ ) lava flows, circumvent and intravent breccia, agglutinate, and subordinate scoria that make up uppermost $150-250 \mathrm{~m}$ of Mount Adams. Overlies olivine-richer, lesssilicic andesite of unit app that makes up bulk of high cone; emplacement interval was shortlived relative to that of app. Principally consists of a fragmental $1-\mathrm{km}$-wide cone that forms the true summit, infills former summit craters, and moderates relief on the broad summit plateau; partly obscured by summit icecap. Most lavas exposed on south slope of the cone are vitrophyric, vesicular, $1-5 \mathrm{~m}$ thick, and dominated by rubbly zones; interiors of lava flows (as thick as $20 \mathrm{~m}$ ) on east face of summit cone are massive and crystalline. Ejecta range from sparse cinders to angular blocks of vitrophyre, some prismatically jointed, in an altered, ash-rich, poorly stratified matrix; in part emplaced phreatomagmatically. Clasts and breccia blocks of phenocryst-poor dacite $\left(64 \% \mathrm{SiO}_{2}\right.$; sparse plag, opx, and $\left.\mathrm{cpx}\right)$ are common in Holocene till and avalanche debris of Adams Glacier; glassy to finely crystalline, massive or flow-banded, they are evidently derived from an extrusion wholly concealed by the summit icecap. Bold hachured lines indicate craters. Dot-dash line represents abrupt attitude change where ejecta drape an older crater rim. Most fragmental material is fumarolically altered, yielding same acid-sulfate assemblage given for subjacent unit app.
Phenocrysts: $11-21 \%$ plag $(0.5-4 \mathrm{~mm})$; $0.5-$ $2 \% \mathrm{cpx}(0.5-1.5 \mathrm{~mm}) ; 1.5-3.5 \%$ opx $(0.5-$ $2 \mathrm{~mm}$ ); less than $1 \%$ olivine (mostly smaller than $0.5 \mathrm{~mm}$ ); and sparse $\mathrm{Fe}$ - $\mathrm{Ti}$ oxides. K-Ar age: $15 \pm 8 \mathrm{ka}$, at true summit. Conceivably of very early Holocene age

$a b b$

Andesite of Bunnell Butte (late Pleistocene)Phenocryst-poor olivine-andesite $\left(57 \% \mathrm{SiO}_{2}\right)$ lava flows and three small cinder cones aligned northwest-southeast on the north-northwest flank of King Mountain (unrelated). Flows are thin, rubbly, little eroded, but poorly exposed; one tongue extends $7 \mathrm{~km}$ southwest. Phenocrysts: $2 \%$ olivine (smaller than $1 \mathrm{~mm}$ ) and traces of tiny plag, cpx, and opx (all less than $0.5 \mathrm{~mm}$ ). Overlain by units asm and bsb; overlies bkm and aeb. Undated

abc Andesite of Bacon Creek (early Pleistocene)Sparsely porphyritic olivine-plagioclase basalt and andesite $\left(51.5-55 \% \mathrm{SiO}_{2}\right)$ lava flows erupted from shield 2971 between Bacon and Dairy Creeks. Poorly exposed flows spread $5 \mathrm{~km}$ southeast to the Klickitat River. Thickly mantled with loessic soil, unit is weathered and eroded, locally displaying more than $50 \mathrm{~m}$ relief; crops out as rounded slabs and bouldery corestones, typically massive and holocrystalline, the vesicular surface having largely been removed. Phenocrysts: 1 $4 \%$ olivine (0.5-1 $\mathrm{mm}$, rarely to $3 \mathrm{~mm}$ ), some in clusters and commonly rimmed by iddingsite; $2-6 \%$ plag $(0.5-1.5 \mathrm{~mm})$; sparse opx and $\mathrm{cpx}$. Groundmass plag abundant, conspicuous in weathered rocks. Younger than adjacent units aah and bah; older than bof, adc, dhd, and apc. K-Ar age: $903 \pm 13 \mathrm{ka}$

abe Andesite east of Babyshoe Ridge (middle? Pleistocene)-Pyroxene-andesite $\left(56 \% \mathrm{SiO}_{2}\right)$ lava-flow remnant banked against eastern spur of Babyshoe Ridge at the northwest base of Mount Adams. Glacial erosion has left only a drift-surrounded, 300-m-long, isolated rib of vesicular, vitrophyric flow-breccia $20 \mathrm{~m}$ thick; apparently the margin of a once-extensive lava flow now largely removed by ice. Source unknown; chemically unlike any other unit exposed in the sector. Phenocrysts: $25 \%$ plag $(0.5-5 \mathrm{~mm}) ; 4 \%$ opx $(0.5-2 \mathrm{~mm})$; less than $1 \% \mathrm{cpx}(0.5-1.5 \mathrm{~mm})$. Secondary minerals conspicuous in vesicles. In contact only with Tertiary rocks and surficial deposits. Location and condition suggest that this remnant could be younger than nearby units alw and dsc. Undated; conceivably of early Pleistocene or Tertiary age

abh

Andesite breccias of Hellroaring Creek (middle Pleistocene)-Pyroxene-andesite (58-62\% $\mathrm{SiO}_{2}$ ) fragmental flow deposits exposed on cliffs west of Hellroaring Meadow and in a recently deglaciated window near 
Sunrise Camp. The crudely stratified, moderately indurated, southwest-dipping deposits were derived from the deeply eroded Hellroaring Volcano (see unit ahv), apparently emplaced on its southwest flank by lava-debris avalanches initiated by disintegration of lava flows over ice or steep terrain. Main cliff exposure is $50-100 \mathrm{~m}$ thick and $1.4 \mathrm{~km}$ long, sandwiched between lava flows of unit ahv. Crudely stratified, the lower $2 / 3$ consists of numerous lenticular flow units $0.3-4 \mathrm{~m}$ thick, generally matrix-supported except for the coarsest units; the upper $1 / 3$ is coarser than below and only vaguely stratified (by discontinuous stringers of coarse clasts). The 10-m-thick exposure south of Sunrise Camp consists of at least three normally graded, matrix-rich flow units, each 1$2 \mathrm{~m}$ thick, and a coarser capping unit that is about $5 \mathrm{~m}$ thick and clast supported. Largest clasts in most flow units are typically 15-50 $\mathrm{cm}$, but some exceed $2 \mathrm{~m}$. Most are juvenile, glassy, and show a wide range of vesicularity, from massive vitrophyre to scoria; the more vesicular clasts tend to be subrounded, others subangular. Fewer than 10 percent of clasts are identifiable as accidental, being oxidized, devitrified, or of lithologically different andesite. The fines-poor matrix consists mostly of coarse ash and granules created by granulation of clast material; it makes up as much as 80 percent of a few thin flow units (or zones thereof) but generally less than 25 percent of the predominant coarser ones. Matrix material is ochre to rusty orange brown, locally iron stained, variably indurated, and rich in montmorillonite; most clasts, however, remain black or gray and are little-altered except for films of secondary minerals along fractures and vesicles. Phenocrysts (in clasts): $8-15 \%$ plag $(0.5-3 \mathrm{~mm}) ; 1-2 \%$ each opx and cpx $(0.5-1.5 \mathrm{~mm}) ; 0.5-1 \% \mathrm{Fe}$-Ti oxides (0.2-0.5 mm); sparse olivine microphenocrysts. Overlain by units app and ahr and intruded by numerous dikes of unit adh; intercalated with lava flows of unit ahv $(0.5 \mathrm{Ma})$

$a b l$

Andesite of Bird Lake (middle Pleisto-cene)Moderately porphyritic pyroxene-andesite $\left(57 \% \mathrm{SiO}_{2}\right)$ lava flow, exposed patchily within $1 \mathrm{~km}$ of Bird Lake. Vent concealed by younger lavas, presumably toward Mount Adams. Exposures are glacially eroded, driftstrewn, slabby or knobby, with maximum relief of about $25 \mathrm{~m}$. Phenocrysts: $10-12 \%$ plag (0.5-2.5 mm); $2 \%$ opx (0.5-1 mm); $0.5 \% \mathrm{cpx}$ $(0.5-1 \mathrm{~mm})$. Overlies unit dhd $(304 \pm 5 \mathrm{ka})$; overlain by $d b c(115 \pm 5 \mathrm{ka})$ and app. Undated Olivine-andesite $\left(54.5 \% \mathrm{SiO}_{2}\right)$ lava flows and scoria erupted on Battlement Ridge
$400 \mathrm{~m}$ southwest of The Spearhead. Subdued depression marks small field of cinders and spatter at source of two 1-km-long tongues of glassy scoriaceous lava, each as thick as $6 \mathrm{~m}$ (of which the central $2 \mathrm{~m}$ is massive). Southerly tongue is enclosed within Neoglacial till of left-lateral moraine of Klickitat Glacier. Phenocrysts: $17 \%$ plag $(0.5-2 \mathrm{~mm}$, rarely to $6 \mathrm{~mm}$ ); $3 \%$ each of olivine and $\mathrm{cpx}$ (both 0.5-1 mm); sparse opx and $\mathrm{Fe}-\mathrm{Ti}$ oxides. Younger than all nearby volcanic units. Undated; probably younger than 4 ka

abs

Andesite of Big Spring Creek (late Pleistocene)-Plagioclase-rich pyroxene-andesite $\left(58.5 \% \mathrm{SiO}_{2}\right)$ lava flow(s) forming a $7-\mathrm{km}$-long tongue on the lower west-northwest flank of Mount Adams. Source presumably on or under present-day high cone; proximal extent of unit is concealed by till and Holocene lavas of unit atm. Everywhere glacially scoured, drift-strewn, soil-covered, and largely stripped of its blocky vesicular carapace (except near its terminus). Exposures are mostly crystalline, massive, and platy to slabby, although partly glassy, polygonally jointed or brecciated, lower and marginal zones crop out locally. Phenocrysts: $20-25 \%$ plag $(0.5-3.5 \mathrm{~mm}) ; 2-3 \%$ each of opx and $\mathrm{cpx}(0.5-1.5 \mathrm{~mm})$; and sparse $\mathrm{Fe}-\mathrm{Ti}$ oxides (to $0.5 \mathrm{~mm}$ ). Younger than all contiguous volcanic units except atm. Probably time-correlative with parts of units asc and app. K-Ar age: $28 \pm 6 \mathrm{ka}$

abt Andesite of Big Tree knob (middle Pleistocene)-Plagioclase-rich pyroxene-andesite $\left(56 \% \mathrm{SiO}_{2}\right)$ lava that forms part of eroded knob 2896, $200 \mathrm{~m}$ southeast of Trout Lake Big Tree (6 km north of Trout Lake). Knob is not an eruptive center but a drift-veneered kipuka (former nunatak?) composed of 3 different units (abt, bbt, aha). Andesite mostly covered by thick soil, but scattered outcrops on top remain blocky but rounded and degraded, partly glassy but strongly weathered, and locally vesicular with abundant secondary minerals. Phenocrysts: $25 \%$ plag $(0.5-$ $3 \mathrm{~mm}) ; 6 \% \mathrm{cpx}(0.5-1.5 \mathrm{~mm}) ; 2.5 \%$ opx $(0.5-2 \mathrm{~mm})$. Older than surrounding units dhg and bew ( $329 \pm 50 \mathrm{ka})$; probably older than bbt and aha. May actually be an erosional outlier of unit aws (2 km to west). Undated

abu Andesite southwest of Butter Cave (middle Pleistocene)-Aphyric andesite $\left(57 \% \mathrm{SiO}_{2}\right)$ lapilli and blocks as large as $1 \mathrm{~m}$, forming a 60-m-high scoria cone north of Cave Creek, surrounded by valley-filling basalts of much younger unit bic. Isolated kipuka of finely vesicular (0.1-0.3 mm), partly glassy ejecta, light to medium gray (commonly oxidized tan, pale purple, or ochre), and virtually devoid of phenocrysts. Poorly exposed, but soil cover not thick. Groundmass is peppered with tiny opaque $\mathrm{Fe}$ - $\mathrm{Ti}$ oxides and contains 1-2 per- 
cent euhedral olivine $(0.2-0.5 \mathrm{~mm})$ and abundant plag microlites. Undated

aby

Andesite south of Sleeping Beauty (middle? Pleistocene)-Sparsely porphyritic olivineandesite $\left(55 \% \mathrm{SiO}_{2}\right)$ lava-flow remnant capping benches north of Trout Lake Creek, about $2 \mathrm{~km}$ southwest of Sleeping Beauty. Source unknown; probably in Indian Heaven volcanic field west of the map area. Isolated remnant is $2 \mathrm{~km}$ long, and as thick as $110 \mathrm{~m}$. Tillstrewn and glacially eroded, most exposures are finely crystalline, nonvesicular, and platy to slabby. Phenocrysts: $3-4 \%$ olivine $(0.5-1.5 \mathrm{~mm}) ; 1 \% \mathrm{cpx}(0.5-1 \mathrm{~mm})$; plag restricted to groundmass. Rests exclusively on Tertiary rocks; base is now $120-180 \mathrm{~m}$ above Trout Lake Creek. Undated

acb

Andesite of Cakey Butte (middle Pleistocene)-Sparsely porphyritic olivine-andesite $\left(53-57 \% \mathrm{SiO}_{2}\right)$ lava flows north of Trout Lake, erupted at dike complex eroded as cliffy spur on southwest face of Cakey Butte. Glacial drift (go) that discontinuously mantles this unit is omitted for clarity. Stack of several flows making up till-strewn plateau northeast of Trout Lake Creek has a cumulative exposed thickness of more than $150 \mathrm{~m}$ (locally perhaps $200 \mathrm{~m}$ ); internal contacts are rarely exposed. Drilling north of Trout Lake (Jones, 1960) showed that the stack extends downward for at least an additional $35 \mathrm{~m}$ below level of valley floor. Outcrops are mostly massive, platy, nonvesicular, and crystalline, the surface having everywhere been glacially stripped. Remnant on southwest wall of Trout Lake Creek suggests severe erosion, presumably glacial, prior to eruption of overlying unit bcb. Phenocrysts: $3-6 \%$ olivine $(0.5-1.5 \mathrm{~mm}$, rarely to $3 \mathrm{~mm})$; 0-3\% plag (0.5-1 $\mathrm{mm}$ ); and sparse $\mathrm{cpx}$ (in dikes and some flows). Generally distinguishable from lavas of unit bcb by abundant plag microlites (commonly flow-aligned) and lack of olivine-peppered groundmass. Older than all contiguous Quaternary units except aws (which it probably contacts in subsurface). $\mathrm{K}$-Ar age: $259 \pm 35 \mathrm{ka}$, at southeast limit of exposure. Apparent conflict between radiometric ages of unit acb and overlying unit bew $(329 \pm 50 \mathrm{ka})$ could conceivably signify more than one eruptive episode for acb, but the difficulty probably lies in analytical resolution, not stratigraphy

acg Andesite of Crooked Creek-Gotchen Creek divide (middle Pleistocene)-Olivine-pyroxene andesite $\left(54-55.5 \% \mathrm{SiO}_{2}\right.$ ) lava and agglutinated scoria forming an isolated knob and $300-\mathrm{m}$-long bench on the divide $1 \mathrm{~km}$ west of Bird Lake. Glacially eroded remnant includes part of its own vent complex. Brickred, finely vesicular, lightly welded scoria as thick as $15 \mathrm{~m}$ is exposed on southerly knob,

grading to massive lava on its east face; remainder of outcrop is a cliffy bench of crystalline, hackly to slabby, gray lava. Phenocrysts: $8-10 \%$ plag $(0.5-5 \mathrm{~mm}) ; 2 \%$ olivine $(0.5-1.5 \mathrm{~mm}) ; 3 \% \mathrm{cpx}$ and $1.5 \%$ opx (both 0.5-2.5 mm); plag-cpx clusters as large as $1 \mathrm{~cm}$ are common. Apparently older than all surrounding units, but glacial drift obscures contacts. Undated

acn

acr dc

Andes $\left(57 \% \mathrm{SiO}_{2}\right)$ lava flows forming two discrete tongues, one along Dairy Creek, another north of Cougar Creek. Vent unknown, concealed by till and younger lavas. As thick as $\mathbf{3 0}$ $\mathrm{m}$, flows are weathered and soil covered but remain blocky, glassy, and vesicular. Phenocrysts: $24-30 \%$ plag (1-6 mm), commonly equant prisms, pronounced by weathering and riddled with glass inclusions; $4-5 \%$ each cpx and opx (0.5-2 mm); and $2-3 \%$ olivine (smaller than $1 \mathrm{~mm}$ ). Older than contiguous Quaternary units except aah and abc. K-Ar age: $425 \pm 7 \mathrm{ka}$ 

tocene)-Phenocryst-poor andesite $154.5 \%$ $\mathrm{SiO}_{2}$ ) lava flow, just east of Draper Springs Camp. Only the distal $1 \mathrm{~km}^{2}$ is exposed; source probably lies to northwest, concealed by younger lavas. Flow has little relief, covered by alluvium and loess-rich colluvium. Sparse exposures are massive, nonvesicular, and holocrystalline to partly glassy. Phenocrysts: $1 \%$ plag $(0.5-1 \mathrm{~mm})$, less than $0.5 \%$ olivine (as large as $0.5 \mathrm{~mm}$ ), and trace $\mathrm{Fe}-\mathrm{Ti}$ oxides. Overlain by unit ads; probably younger than bgo. Undated; older than unit bbj $(940 \pm 36 \mathrm{ka})$

Andesite of Devils Gardens (late Pleistocene)-Pyroxene-andesite $\left(58-59 \% \mathrm{SiO}_{2}\right)$ lava flows erupted on northeast flank of Mount Adams, 1-2 km south of Red Butte. An asymmetrical shield was constructed by numerous flows that issued effusively from two exposed vents and from others now concealed at Devils Gardens. Upper surface of shield is unglaciated, scoriaceous to blocky vitrophyre, but upper margins and lower flanks are till-strewn and glacially stripped, exposing massive or slabby, crystalline interiors of flows. Maximum exposed relief about $100 \mathrm{~m}$, proximally. Phenocrysts: $20-25 \%$ plag $(0.5-3 \mathrm{~mm}) ; 4 \%$ opx and $1 \% \mathrm{cpx}$ (both $0.5-1.5 \mathrm{~mm}$ ). Overlies units bgt, awg, and alm; overlain by btc and amf; unit awf $(55 \pm 7 \mathrm{ka})$ predates adg but could be an early eruptive phase from same vent complex. K-Ar age: $37 \pm 8 \mathrm{ka}$, at knob 6622 ; a sample from shield surface was too young to date, yielding a nominally negative age

Andesite dikes of Hellroaring volcano (middle Pleistocene)-Pyroxene-andesite (56-63\% $\mathrm{SiO}_{2}$ ) dikes cutting units ahv, abh, $\mathrm{dth}$, and dts of deeply eroded Hellroaring volcano, on Ridge of Wonders and walls of Hellroaring and Big Muddy Creeks. Dikes are $0.1-5 \mathrm{~m}$ thick, strike $105^{\circ}-170^{\circ}$ (mostly $120^{\circ}-150^{\circ}$ ), and dip vertically to $70^{\circ} \mathrm{NE}$ (a few segments rolling over to as little as $40^{\circ} \mathrm{NE}$ ). More numerous than depicted, at least 60 dikes were noted, some in swarms of as many as six, some en-echelon, and a few internally composite. Many dikes have thin glassy margins, others are largely vitrophyric, and some fuse tuffs (abh, dth) they intrude; many dike margins are polygonally jointed. Scattered vesicles are common, but where a dike is extensively vesicular, it is typically rich in greenish secondary minerals. Many dikes are strongly weathered, and some show onion-skin decomposition around fresher cores. Unit includes dikes of various ages, as indicated by wide ranges in contents of olivine (0-5\%), cpx (1-3\%), opx (0-3\%), and plag $(10-35 \%)$. No evidence is known relating any of these dikes to the late Pleistocene central-vent system of Mount Adams; no dikes cut units app, ask, or ala; a few are related to eroded scoria-cone remnants of units arw and ati $(385 \pm 7 \mathrm{ka})$. All dikes are thought to predate the glacial canyon-cutting interval (probably 150-130 ka) that deepened Hellroaring Creek, producing the valley floor upon which lavas of unit ala were emplaced at $63 \pm 7 \mathrm{ka}$

ads

Andesite of Draper Springs Camp (early Pleistocene)-Plagioclase-rich pyroxene-andesite $\left(57.5 \% \mathrm{SiO}_{2}\right)$ lava flow exposed in windows at east foot of King Mountain. Source unknown, concealed to northwest by younger lavas. Poorly exposed nonglaciated surface is partly glassy, slightly vesicular, deeply weathered, little-incised, covered by loess-rich soil and colluvium; subdued relief reaches $15 \mathrm{~m}$ locally. Phenocrysts: $25-30 \%$ plag (1-4 mm, a few to $6 \mathrm{~mm}$ ); $2-3 \%$ each of $\mathrm{cpx}$ and opx $(0.5-2 \mathrm{~mm}) ; 1-2 \%$ olivine $(0.5-1 \mathrm{~mm})$. Overlies units bgo and ade; overlain by bbj and bkm. Undated, but bracketed by older unit bgo and younger unit bbj $(940 \pm 36 \mathrm{ka})$

aeb Andesite east of Bunnell Butte (late Pleistocene)-Pyroxene-andesite $\left(61 \% \mathrm{SiO}_{2}\right)$ lava flows cropping out in windows between Bird Creek and Bunnell Butte. Vent unknown, covered by till or younger lavas. Overlapped by late Pleistocene moraines, but exposures below glacial limit are blocky, vitrophyric, vesicular, with levees and flow fronts having as much as $80 \mathrm{~m}$ local relief. Phenocrysts: $20 \%$ plag $(0.5-4 \mathrm{~mm}$, rarely $6 \mathrm{~mm})$; $2-3 \%$ opx $(0.5-3 \mathrm{~mm}) ; 1 \% \mathrm{cpx}(0.5-2.5 \mathrm{~mm})$. Younger than unit bkm (106 $\pm 25 \mathrm{ka})$; older than abb and asm. Undated aes aff
Andesite east of Shadow Lake (late Pleistocene)-Plagioclase-rich pyroxene-andesite $\left(60 \% \mathrm{SiO}_{2}\right)$ lava flow, agglutinate, and scoria erupted at cinder-spatter cone (5820) about $1 \mathrm{~km}$ southwest of Bench Lake. Cone was constructed near rim of the already deep canyon of Hellroaring Creek; subsequent late Pleistocene glaciation deposited till against the cone and truncated its steep north face. Lava flow extends $7 \mathrm{~km}$ southeast into upper Bacon Creek; its surface is blocky, vitrophyric, vesicular, little-eroded, and largely driftless, although overlapped by moraines along both margins. Phenocrysts: $30 \%$ plag $(0.5-5 \mathrm{~mm})$; $4 \%$ opx $(0.5-1.5 \mathrm{~mm})$. Younger than all contiguous volcanic units. K-Ar age: $111 \pm 6$ ka

Andesite of Foggy Flat (middle Pleistocene)Pyroxene-andesite $\left(59.5-62 \% \mathrm{SiO}_{2}\right)$ lava flows characterized by abundance of unusually large plagioclase phenocrysts, exposed in glaciated windows on north flank of Mount Adams. Source concealed by younger lavas of main cone. Ice-scoured surfaces are marked by knobs and benches excavated from stacks of flows each typically 5-30 m thick; maximum known 
cumulative thickness is $70 \mathrm{~m}$ but could be much greater, as base of the pile is nowhere exposed. Rubbly flow-breccia zones and platyslabby (or massive) crystalline internal zones are widely exposed; lower and marginal vitrophyric zones are commonly massive or polygonally jointed; vesicular surfaces have generally been stripped. Well exposed proximally, but distal parts are till mantled. Phenocrysts: $25-30 \%$ plag $(0.5-8 \mathrm{~mm}) ; 4-5 \%$ opx (0.5-1.5 mm); $3 \% \mathrm{cpx}(0.5-1.5 \mathrm{~mm})$; less than $1 \% \mathrm{Fe}$-Ti oxides; no olivine. Older than olivinebearing andesitic units amf and app; overlies unit awm. Some map contacts are only approximate, owing to local intercalation of bigfeldspar flows with otherwise similar pyroxene-andesite flows of unit akc containing ordinary 1-4 mm plag. $\mathrm{K}$-Ar age: $152 \pm 8$ ka

agc Andesite of lower Gotchen Creek (middle Pleistocene)-Plagioclase-rich olivine-pyroxene andesite $\left(53 \% \mathrm{SiO}_{2}\right)$ lava flow with limited exposure along north margin of Trout Lake Valley and lowermost Gotchen Creek. Largely concealed by younger lavas; source unknown, presumably farther north. Exposures are nonglaciated, weathered, and soil covered, with little relief; vesicular vitrophyric surface survives locally; massive and crystalline along draws. Phenocrysts: $25 \%$ plagioclase $(0.5-4 \mathrm{~mm}) ; 1 \%$ olivine (smaller than $1 \mathrm{~mm}$ ); $2 \%$ each of opx and cpx (both $0.5-2 \mathrm{~mm}$ ). Overlain by units bhb $(209 \pm 21 \mathrm{ka})$ and bsb. Undated

Andesite west of Gotchen Glacier (Holocene)-Pyroxene-andesite $\left(58 \% \mathrm{SiO}_{2}\right)$ lava flow erupted on lower Suksdorf Ridge and ponded against South Butte. Effusive vent is inconspicuous, with only sparse scoria. Flow is about $100 \mathrm{~m}$ wide, less than $1 \mathrm{~km}$ long, and less than $10 \mathrm{~m}$ thick; everywhere vitrophyric, vesicular, blocky to rubbly, soilfree, and uneroded. Phenocrysts: $12 \%$ plag $(0.5-2.5 \mathrm{~mm}) ; 3 \% \mathrm{cpx}(0.5-2 \mathrm{~mm}) ; 1.5 \% \mathrm{opx}$ $(0.5-2 \mathrm{~mm})$; and sparse olivine $(0.5-0.75 \mathrm{~mm})$. Compositionally distinct from subjacent andesitic lavas of unit ask $\left(56.5 \% \mathrm{SiO}_{2}\right)$ and from nearby Holocene unit aaa $\left(59 \% \mathrm{SiO}_{2}\right)$

aha Aphyric andesite west of Hole-in-the-Ground Creek (middle Pleistocene)-Phenocrystpoor olivine-andesite $\left(56 \% \mathrm{SiO}_{2}\right)$ scoria erupted at inconspicuous center $600 \mathrm{~m}$ northeast of Trout Lake Big Tree $(7 \mathrm{~km}$ north of Trout Lake). No lava flows exposed. Exposure poor; mostly finely vesicular blocks, oxidized or medium-gray, and loose cinders in thick loessic soil. Scoria blocks as large as $50 \mathrm{~cm}$ occur at both principal outcrops, which are separated and enveloped by weathered glacial drift (go). Phenocrysts: $3-5 \%$ olivine $(0.5-1 \mathrm{~mm})$; sparse microphenocrysts of plagioclase and olivine. Ejecta apparently drape shoulder of unit abt on Big Tree knob. Older than adjacent unit bew $(329 \pm 50 \mathrm{ka})$. Undated

ahc Andesite of High Camp (Holocene)-Olivine-pyroxene andesite $\left(58-59.5 \% \mathrm{SiO}_{2}\right)$ lava flows extending $1.5 \mathrm{~km}$ west-northwest from Neoglacial moraines of Adams Glacier. Source is largely concealed by these moraines or by ice, although knob 7360+ (at eastern limit of exposure) is a subsidiary effusive vent. Flow surfaces are largely glassy, vesicular, blocky to rubbly; massive crystalline interior is exposed locally where scoured by Holocene ice. Thickness generally less than $10 \mathrm{~m}$; flows thinned and broke up while pouring over steep benches. Phenocrysts: $15 \%$ plag $(0.5-3 \mathrm{~mm}) ; 1 \%$ each of $\mathrm{cpx}(0.5-2.5 \mathrm{~mm})$ and olivine (smaller than $1 \mathrm{~mm}$ ); and $0.5 \%$ opx (to $1.5 \mathrm{~mm}$ ). Vesicles commonly elongate in flow direction. Compositionally distinct (less potassic) from similar Holocene unit atm nearby. Younger than all contiguous volcanic units

ahg Andesite of Hole-in-the-Ground Creek (late Pleistocene)-Plagioclase-rich pyroxene andesite $\left(62-63 \% \mathrm{SiO}_{2}\right)$ lava flows forming an 8-km-long tongue on lower south flank of Mount Adams. Vent is concealed farther north by till or younger lavas. Rugged flow surfaces commonly have tens of meters of local relief, reflecting superimposed lobes; distal flow fronts are 50-100 m high. Although proximally overlain by till, nearly all exposures are outside late Pleistocene glacial limit; surfaces remain blocky, vitrophyric, vesicular, and littleincised, with only moderate soil cover. Phenocrysts: $21 \%$ plag $(0.5-6 \mathrm{~mm})$, much of it conspicuously larger than in most andesites at Mount Adams; $4 \%$ opx $(0.5-2.5 \mathrm{~mm}) ; 2 \%$ cpx (0.5-2.5 mm); and 1-2\% Fe-Ti oxides (0.2$0.5 \mathrm{~mm}$ ). Overlies units $\mathrm{dhg}$, bew, amc, and asm; overlain by asb, bsb, aaa, and late Pleistocene till (gy). Undated, but bracketed by units amc (56 $\pm 6 \mathrm{ka})$ and gy (25-11 ka)

ahr Andesite of Hellroaring Cliffs (middle Pleistocene)-Modestly porphyritic pyroxeneolivine andesite $\left(58 \% \mathrm{SiO}_{2}\right)$ lava flow forming glaciated southeast-sloping bench atop cliffs west of Hellroaring Meadow. Source concealed to northwest beneath Mount Adams. Lava is medium gray, massive, crystalline, everywhere glacially scoured and drift strewn. Phenocrysts: $5 \%$ plag $(0.5-1 \mathrm{~mm}$, rarely to $3 \mathrm{~mm}) ; 1.5 \%$ olivine $(0.5-2 \mathrm{~mm})$; less than $1 \%$ each opx and cpx (both $0.5-1 \mathrm{~mm}$ ). Underlies unit dbc ( $115 \pm 5 \mathrm{ka})$; overlies abh, beneath which unit ahv is dated at $516 \pm 10 \mathrm{ka}$. Undated

aht Andesite of Highline Trail (middle Pleistocene)-Sparsely porphyritic pyroxene-andesite $\left(58-60 \% \mathrm{SiO}_{2}\right.$ ) lava flow(s) forming till-mantled plateau on northwest side of Goat 
Butte. Source unknown; probably beneath Mount Adams. Unit is severely eroded glacially; most exposures are crystalline, massive, platy to slabby with pale-gray or tan mottles, but scoriaceous remnants are present on plateau rim. Maximum surviving thickness $25-30 \mathrm{~m}$. Phenocrysts: $2 \%$ plag (mostly less than $1 \mathrm{~mm}$; a few laths $1-3 \mathrm{~mm}$ ); $0.5 \%$ each opx and cpx; and sparse olivine. Overlies old plagioclase-rich andesite lavas of unit ahv $(0.5 \mathrm{Ma})$; probably underlies bgt $(159 \pm 31 \mathrm{ka})$ but till obscures contact. Undated

ahv

Andesite of Hellroaring Volcano (middle Pleistocene)-Pyroxene-andesite $\left(57-61 \% \mathrm{SiO}_{2}\right)$ and sparse pyroxene-dacite $\left(64 \% \mathrm{SiO}_{2}\right)$ lava flows and subordinate intercalated fragmental deposits of a deeply eroded former edifice, remains of which make up much of Ridge of Wonders and walls of Big Muddy and Hellroaring Creeks, from near Sunrise Camp eastward almost to Klickitat River. Radial dips of lavas and local concentration of dikes (unit adh) suggest that a long-lived middle-Pleistocene stratocone was centered above present-day site of uppermost Big Muddy Creek, 3-4 km east-southeast of modern summit of Mount Adams. Exposures are as thick as $550 \mathrm{~m}$, but nowhere is base exposed. Numerous lava flows are as thin as $3-5 \mathrm{~m}$, commonly 10 $20 \mathrm{~m}$, and as thick as $80 \mathrm{~m}$. Platy and massive crystalline zones dominate ledgy exposures, but vesicular, glassy, basal breccias and blockyto-rubbly flow tops crop out locally. Phenocryst contents range widely: $0-4 \%$ olivine, $1-4 \%$ each of cpx and opx, and $15-30 \%$ plag. Related units include the following: (1) isolated unit dts probably also erupted from Hellroaring Volcano; (2) dth is a pumiceous pyroclastic-flow deposit intercalated low within the ahv pile; and (3) abh is a group of scoriaceous and lithic fragmental-flow deposits high in the ahv pile. Older than all other contiguous volcanic units. K-Ar ages: $502 \pm 9 \mathrm{ka}$ for the lowest lava flow exposed in Big Muddy Creek; $516 \pm 10$ ka for the lowest lava flow (a dacite) exposed in Hellroaring Creek; $511 \pm 9$ ka for platy lava flow at quarry $900 \mathrm{~m}$ northwest of Shadow Lake. Upper age range of the ahv pile is limited by overlying unit ati $(385 \pm 7 \mathrm{ka})$, which vented directly through it

akc Andesite of Killen Creek (late Pleistocene)Plagioclase-rich pyroxene-andesite $(58-62 \%$ $\mathrm{SiO}_{2}$ ) lava flows making up much of northnorthwest apron of Mount Adams. Source concealed beneath present-day high cone (app). Everywhere glacially scoured, but glassy carapace is partly preserved north and west of Horseshoe Lake. Phenocrysts: $20-25 \%$ plag (0.5-3 $\mathrm{mm}$; a few to $6 \mathrm{~mm}) ; 4-6 \%$ opx (0.5-1.5 mm); $1 \% \mathrm{cpx}(0.5-1 \mathrm{~mm})$; and traces

of olivine and $\mathrm{Fe}$-Ti oxides (both smaller than $0.5 \mathrm{~mm}$ ). Overlies units dac and aff; overlain by units app and atm. Location of contact with similar-looking lavas of unit app is tentative. K-Ar age: $120 \pm 7 \mathrm{ka}$, at northeast shore of Horseshoe Lake

ala

all

alm
Andesite of Little Mount Adams (late Pleistocene)-Sparsely to moderately porphyritic olivine-pyroxene andesite $\left(55-56 \% \mathrm{SiO}_{2}\right)$ lava flows, scoria, and agglutinate erupted at prominent cinder-spatter cone on southeast flank of Mount Adams. Erupted over steep wall of Hellroaring Creek, which had been cut during older glaciations; upper $250 \mathrm{~m}$ of the cone subsequently stood above late Wisconsin valley glacier, preserving a small agglutinate-rimmed crater and steeply dipping stacks of thin spatterfed lavas. Lower half of the cone and intracanyon lava-flow remnants (preserved as far as $6 \mathrm{~km}$ down Hellroaring Creek) are glacially incised and till mantled. Cumulatively thicker than $75 \mathrm{~m}$ thick near Heart Lake, the exposed valley-filling flows are largely slabby, crystalline, nonvesicular, and 1-15 m thick; scoriaceous zones are well exposed only high on the cone. Phenocrysts: $0-10 \%$ plag (0.5-2.5 mm); $2-4 \%$ olivine $(0.5-1 \mathrm{~mm}) ; 1$ $4 \% \mathrm{cpx}(0.5-1 \mathrm{~mm}$, rarely to $3 \mathrm{~mm}) ; 1-3 \%$ opx (0.5-1.5 mm); sparse Fe-Ti oxides (to $0.5 \mathrm{~mm}$ ); and conspicuous clusters of the 5 species in any combination. Plag-poor lavas and ejecta have about $55 \% \mathrm{SiO}_{2}$; plagricher lavas have about $56 \%$. Younger than all contiguous volcanic units. $\mathrm{K}$-Ar age: $63 \pm 7 \mathrm{ka}$

Andesite of Lookingglass Lake (middle Pleistocene)-Olivine-andesite $\left(53-57 \% \mathrm{SiO}_{2}\right)$ lava flows rimming the 5200'-5800' cliffs around Cascade and Salt Creeks on the southwest flank of Mount Adams. Vent concealed by younger units. Cliff exposures as thick as $70 \mathrm{~m}$, typically consisting of a few flows, each 7-50 m thick. Unit is everywhere strongly scoured glacially, exposing massive crystalline flow interiors with prominent slabby to platy jointing; glassy zones between flows crop out only sparsely. Phenocrysts: $10-12 \%$ plag $(1-3 \mathrm{~mm}$, rarely $5 \mathrm{~mm}) ; 3-4 \%$ olivine $(0.5-2 \mathrm{~mm})$, much of it small and rounded; $2-3 \% \mathrm{cpx}(0.5-2 \mathrm{~mm}) ; 2 \%$ opx $(0.5-1.5 \mathrm{~mm})$; and sparse Fe-Ti oxides (smaller than $0.5 \mathrm{~mm}$ ). Overlies unit aws; overlain by ast, dcc, and app. K-Ar age: $329 \pm 11$ ka

Andesite of Little Muddy Creek (middle Pleistocene)-Olivine-cpx andesite $\left(56-59 \% \mathrm{SiO}_{2}\right)$ lava flow exposed along and near upper reaches of Little Muddy Creek on the northeast flank of Mount Adams. Vent concealed by present summit cone or by Wilson Glacier; flow remnants extend $1.7 \mathrm{~km}$ downstream from the Neoglacial moraine. Unit is everywhere glacially 
eroded, largely stripped of its glassy carapace; exposures are crystalline, massive or platy, locally finely vesicular. Phenocrysts: $12-14 \%$ plag $(0.5-4 \mathrm{~mm}) ; 1 \%$ each olivine and cpx (both 0.5-1 mm); sparse opx and Fe-Ti oxides. Overlies unit dlm; older than awg, adg, and bgt $(159 \pm 31 \mathrm{ka})$. Undated

aln

Andesite north of Little Mount Adams (middle Pleistocene)-Olivine-pyroxene andesite (55\% $\mathrm{SiO}_{2}$ ) lava flows and scoria-cone remnant on the Ridge of Wonders, $500 \mathrm{~m}$ northwest of Little Mount Adams. Largely removed by glacial erosion, the 250-m-wide vent remnant forms a 30-m-high knob, consisting of coarse scoria and spatter, lightly to strongly agglutinated and intruded by a massive dike $3-4 \mathrm{~m}$ thick. Several thin (1-5 m) lava flows form a glacially scoured surface to the east; subordinate zones of agglutinated red flow-breccia alternate with massive finely crystalline, poorly jointed, exceptionally tough lavas identical in composition to vent complex. Uppermost flow retains its blocky vitrophyric surface within a limited drift-free area just north and northeast of cone. Phenocrysts: $12-14 \%$ plag $(0.5-4 \mathrm{~mm}) ; 1 \%$ each of olivine, $\mathrm{cpx}$, and opx (all $0.5-1 \mathrm{~mm}$; rarely $2 \mathrm{~mm} \mathrm{cpx}$ ). Erupted through and overlies unit ahv $(0.5$ $\mathrm{Ma}$ ); apparently younger than contiguous unit arw; degree of cinder-cone erosion is comparable to that of nearby cone of unit ati $(385 \pm 7 \mathrm{ka})$. Predates at least one glaciation older than unit ala $(63 \pm 7 \mathrm{ka})$. Undated

Andesite of Laurel (middle Pleistocene)Sparsely porphyritic hornblende-andesite $(62 \%$ $\mathrm{SiO}_{2}$ ) lava flow from effusive vent $3 \mathrm{~km}$ northwest of Laurel. Flow is weathered, rubblestrewn, and loess covered; massive, either glassy or devitrified, at sparse exposures. Unit is as thick as $90 \mathrm{~m}$ near vent, thinning to about $20 \mathrm{~m}$ at Camas Prairie terminus $4 \mathrm{~km}$ east. Phenocrysts: $5 \%$ plag $(0.5-2 \mathrm{~mm})$; generally oxidized mafic crystals include sparse olivine and opx (both 0.5-1.5 $\mathrm{mm}$ ) and $1 \%$ hornblende $(0.5-1 \mathrm{~mm}$ long). This is one of only two hornblende-bearing lavas in the Mount Adams area. Rests on Columbia River Basalt Group and is older than all other contiguous units, including ams (622 $\pm 15 \mathrm{ka})$. K-Ar age: $631 \pm 21 \mathrm{ka}$

alw Andesite of Lewis River (middle Pleistocene)Plagioclase-rich pyroxene-andesite $\left(61.5 \% \mathrm{SiO}_{2}\right)$ lava flow(s) making up ridges and bluffs on both sides of Lewis River south of Takh Lakh Lake. Source concealed to southeast by younger lavas. Glacially eroded and tillmantled, poorly exposed lava is crystalline, massive, commonly platy, and as thick as $150 \mathrm{~m}$. Phenocrysts: $15-18 \%$ plag $(0.5-4 \mathrm{~mm}$, rarely $6 \mathrm{~mm}) ; 4 \%$ opx $(0.5-2 \mathrm{~mm})$; $1 \% \mathrm{cpx}(0.5-1 \mathrm{~mm})$; sparse $\mathrm{Fe}-\mathrm{Ti}$ oxides (smaller than $0.5 \mathrm{~mm}$ ). Overlies unit dir ( $252 \pm 8 \mathrm{ka})$; overlain by abs and atm. K-Ar age: $251 \pm 6 \mathrm{ka}$

amc Andesite of Morrison Creek (late Pleistocene)-Plagioclase-rich pyroxene-andesite $\left(58 \% \mathrm{SiO}_{2}\right)$ lava-flow apron south of late Pleistocene moraines at Morrison, Wicky, and Holein-the-Ground Creeks. Apron divides distally into two narrow tongues, one forming an intracanyon flow as thick as $60 \mathrm{~m}$ that extends down White Salmon River gorge nearly to Trout Lake Valley. Glacial deposits and younger lavas conceal upper parts of apron, except on drift-free surface of Crofton Ridge. Source lies farther north, concealed by younger lavas, principally by unit app. Much of apron surface remains blocky, vitrophyric, and vesicular, although subdued by loessic soil-especially near the overlying moraines. Where stream-incised, massive crystalline interior zones are exposed. Polygonally jointed, massive vitro-phyric base is exposed on floor of White Salmon River gorge. Phenocrysts: $15-30 \%$ plag $(0.5-4 \mathrm{~mm})$; $4-5 \%$ opx (0.5-1.5 mm); $1-3 \% \mathrm{cpx}(0.5-$ $2.5 \mathrm{~mm})$. Overlies acr $(160 \pm 12 \mathrm{ka})$, dcc $(117 \pm 6 \mathrm{ka})$, and all other contiguous volcanic units except ahg and bsb. K-Ar age: $56 \pm 6 \mathrm{ka}$

amf Andesite of Muddy Fork (Holocene)-Pyroxene-andesite $\left(59-60 \% \mathrm{SiO}_{2}\right)$ lava flows and ejecta erupted from $1.7-\mathrm{km}$-long fissure vent west and southwest of (unrelated) Red Butte. Strip of cinders and agglutinate locate vent system for largely effusive eruptions that built no cone. Thick blocky lavas flowed as far as $8 \mathrm{~km}$ northward, halting against shield 5162 (unit bsc). Everywhere glassy and vesicular, surfaces are commonly craggy and scoriaceous. Little-eroded, but primary relief at flow fronts and margins is typically 15-25 m. Muddy Fork has spread alluvium across parts of the western surface, subduing local relief and supporting forests. Phenocrysts: $20-25 \%$ plag $(0.5-2 \mathrm{~mm}$, a few 3-4 mm); $1-2 \% \mathrm{cpx}$ and 4-6\% opx (both $0.5-2 \mathrm{~mm}$ ); $\mathrm{Fe}-\mathrm{Ti}$ oxides and sparse olivine mostly smaller than $0.25 \mathrm{~mm}$. Younger than all contiguous volcanic units. Proximally overlain by Neoglacial till and outwash. One of youngest eruptive units at Mount Adams; its age is between those of regional ashfall layers with ${ }^{14} \mathrm{C}$ ages of 6.8 (Mazama ash) and 3.5 ka (St. Helens layer Ye)

ams

Andesite of Mud Spring (middle Pleistocene)-Sparsely porphyritic olivine-andesite $\left(54 \% \mathrm{SiO}_{2}\right)$ lava flows and subdued elongate cinder cone southwest of Meadow Butte (unrelated). Lobate flow complex, deeply weathered and loess-covered, extends $5 \mathrm{~km}$ south of cone and is as thick as $60 \mathrm{~m}$ medially, thinning to about $25 \mathrm{~m}$ distally. Phenocrysts: $1-5 \%$ plag $(0.5-1 \mathrm{~mm})$, rarely larger, 
but abundant groundmass laths are locally conspicuous; $2-4 \%$ olivine (smaller than $1 \mathrm{~mm}$ ); and less than $1 \%$ each $\mathrm{cpx}$ and opx (smaller than $1 \mathrm{~mm}$ ). Younger than contiguous units alr and bhc, but older than bmb and bqb. K-Ar age: $622 \pm 15 \mathrm{ka}$ Pleistocene)-Olivine-andesite $\left(53-54 \% \mathrm{SiO}_{2}\right)$ scoria and lava erupted at cinder cone 4028, $1 \mathrm{~km}$ west of Flattop Mountain. Cinder-strewn flanks are mantled by loess-rich colluvium and (on southwest slope) by minor till. Blocky extrusive lava remnant on top is coarsely to slightly vesicular, disintegrating into joint blocks and talus. Phenocrysts: $6-7 \%$ olivine (0.5-1 mm, rarely to $2 \mathrm{~mm}) ; 1 \%$ plag $(0.5-$ $2 \mathrm{~mm}$ ). Thought to be older than the less degraded, nearby basaltic cones of unit bfm (394 $\pm 12 \mathrm{ka})$. Undated

Andesite of Parrott Crossing (late Pleistocene)-Pyroxene-andesite $\left(59-60 \% \mathrm{SiO}_{2}\right)$ intracanyon lava flow along Klickitat River (Sheppard, 1967b). Erupted from a nowconcealed source near Bench Lake, it filled lower Hellroaring Creek and entered the Klickitat gorge between Big Muddy and Cunningham Creeks where its thickness reaches $170 \mathrm{~m}$; it spread $3 \mathrm{~km}$ upstream and $15 \mathrm{~km}$ downstream, thinning in both directions. Consists of a single cooling unit with 5-10 m glassy (vesicular to massive) zones enveloping a platy to massive, crystalline interior; spectacular sets of columnar joints are widely developed. Opposite Jungle Butte, a thin scoriaceous internal parting locally suggests two flow units. Covered by loessic soil and, near Big Muddy Creek, by glacial drift of at least two ages. Phenocrysts: $20-25 \%$ plag $(0.5-3 \mathrm{~mm}$, rarely $5 \mathrm{~mm}$ ); $1-2 \%$ opx (0.5$1.5 \mathrm{~mm}) ; 1-3 \% \mathrm{cpx}(0.5-2.5 \mathrm{~mm})$; less than $1 \% \mathrm{Fe}$-Ti oxides (smaller than $0.5 \mathrm{~mm}$ ); olivine $(0.5-1.5 \mathrm{~mm})$ sparse to absent. Younger than contiguous volcanic units except bcc and ala. Apparent source is near vent for unit aes, which is chemically similar, comparable in phenocryst assemblage, and only slightly younger. K-Ar age: $120 \pm 5 \mathrm{ka}$

Andesite of Pikers Peak (late Pleistocene)Olivine-bearing pyroxene-andesite $\quad 55-60 \%$ $\mathrm{SiO}_{2}$ ) lava flows, agglutinate, and scoria making up most of high cone and glacial cleavers of Mount Adams, including its south shoulder (Pikers Peak) and much of its west peak (The Pinnacle). Compositionally varied magmas erupted intermittently (probably for at least a few thousand years) from a summit-crater complex of changing morphology. Phreatomagmatic, strombolian, spatter, and effusive phases of numerous eruptions filled successive craters with variably dipping, stratified cinders, agglutinates, intravent brec- cias, and autobrecciated lava flows. Bold hachured lines mark segments of crater rims still physiographically expressed; dot-dash lines indicate abrupt changes in attitude of stratified ejecta, apparently marking buried rims of yet older craters. Some spatter-fed and effusive lavas spilled outward to build stacks of numerous, thin (1- to 8-m), very rubbly flows that dip radially away from summit area at $25^{\circ}-35^{\circ}$. Many transformed into lava-debris avalanches by disintegration over ice or cliffs. A few such effusions were sufficiently voluminous to flow out onto apron beyond the $7500^{\prime}(2300 \mathrm{~m})$ break-in-slope at base of the steep cone; most andesitic lavas of the apron, however, appear to have erupted from flank vents. Excluding massive interior zones of thicker lavas, most products are slightly to coarsely vesicular and at least partly glassy. Breccias and stratified ejecta are (about equally) either dark gray or oxidized brick red. Widely exposed on glacier headwalls, fragmental deposits central to the high cone (both app and aas) are fumarolically altered, commonly white, yellow, orange, or ochre, with extensive development of alunite, kaolinite, gypsum, sulfur, montmorillonite, hematite, goethite, cristobalite, and opal. Phenocrysts: assemblage is constant, but proportions range significantly: $10-25 \%$ plag $(0.5-3 \mathrm{~mm}) ; 1-3.5 \% \mathrm{cpx}(0.5-1.5 \mathrm{~mm}$, rarely to $2.5 \mathrm{~mm}) ; 1-5 \%$ opx $(0.5-1.5 \mathrm{~mm}) ; 0.5-$ $1.5 \%$ olivine $(0.3-1.5 \mathrm{~mm}$, rarely to $3 \mathrm{~mm})$; $0.2-1 \% \mathrm{Fe}$-Ti oxides (smaller than $1 \mathrm{~mm}$ ); and common clusters as large as $5 \mathrm{~mm}$ of any combination of these species. In some lava flows, an abundance of angular crystal fragments (better observed in thin section) suggests spatter-fed eruptions and reincorporation of chilled ejecta into intravent magma. Slightly older than units ask, awc, and summit-capping aas. K-Ar ages: $13 \pm$ 8 ka (atop Pikers Peak); $33 \pm 14$ ka, capping Ridge of Wonders at Sunrise Camp

Andesite of Quigley Butte (late Pleistocene)Olivine-plagioclase andesite $\left(52-54 \% \mathrm{SiO}_{2}\right)$ lava flows and scoria of Quigley Butte shield. These early, shield-forming, plag-rich lavas are exposed beneath later (shield-mantling) olivine-basalt lavas (bqb) that lack plagioclase phenocrysts. Unit also underlies much of Camas Prairie, thinly covered by alluvial and lake deposits. Flows are 1-4 m thick, rubbly to blocky, vesicular, loess covered but little eroded. Phenocrysts: $10-13 \%$ each of olivine $(0.5-2 \mathrm{~mm})$ and plagioclase $(0.5-2.5 \mathrm{~mm})$; $0.5 \%$ each opx and cpx (both as large as $1 \mathrm{~mm}$ ). Flows bank against alr; probably overlie bof beneath Camas Prairie alluvium. Unit is overlain by bqb and bmb. Plag-rich aqb cinders are draped by bqb cinders in proximal window southwest of shield summit. Probably 
only slightly older than bqb $(115 \pm 28 \mathrm{ka})$, which shared same vent system

Andesite of Riley Creek (middle Pleistocene)-Plagioclase-rich pyroxene-andesite $\left(59 \% \mathrm{SiO}_{2}\right)$ lava flows forming the $4200^{\prime}-4500^{\prime}$ cliffs at Mutton and Riley Creeks. Source concealed by younger lavas to southeast. Exposures are largely crystalline, massive or platy; two flows, $20 \mathrm{~m}$ and $30 \mathrm{~m}$ thick, support striking waterfalls on Riley Creek. Phenocrysts: $20 \%$ plag $(1-4 \mathrm{~mm}) ; 2 \%$ each of opx and $\mathrm{cpx}(0.5-1.5 \mathrm{~mm})$. Rests on Tertiary andesites or locally on about $15 \mathrm{~m}$ of glacial deposits (go) at Riley Creek. Overlain by units dir $(252 \pm 8 \mathrm{ka})$, brc, asc, abs, and gy. Undated Pleistocene)-Olivine-bearing plagioclase-rich pyroxene-andesite $\left(60-61 \% \mathrm{SiO}_{2}\right)$ lava flow, dike swarm, and spatter-cone remnant north and northeast of Little Mount Adams. Glacial erosion has reduced the vent cone to a 15 -m-high knob, only $100 \mathrm{~m}$ wide, of lightly agglutinated, oxidized spatter and scoria. This grades eastward into a glaciated remnant of massive to platy crystalline lava and a vertical dike set that extends at least $2 \mathrm{~km}$ eastsoutheast. A main dike $8-15 \mathrm{~m}$ thick is accompanied by a few others, which are parallel, en echelon, and each 1-5 m thick; glassy margins are as thick as $50 \mathrm{~cm}$ and commonly have polygonal joints. Phenocrysts: $15-20 \%$ plag (0.5-4 mm); $2-4 \%$ each of $\mathrm{cpx}$ and opx (0.5-2 $\mathrm{mm}$ ); sparse olivine (to $1 \mathrm{~mm}$ ). Erupted through unit ahv (0.5 Ma); apparently older than contiguous unit ain and overlain by lavas of unit ati ( $385 \pm 7 \mathrm{ka})$. Undated Sparsely porphyritic olivine-andesite $\left(57 \% \mathrm{SiO}_{2}\right)$ lava flows and South Butte cinder-spatter cone. Numerous flows 2-20 m thick, some spatterfed, form a stack as thick as $110 \mathrm{~m}$ proximally, thinning distally. Fissure vent atop cone is marked by many domical tumuli $2-5 \mathrm{~m}$ high. Stack is glacially scoured and laterally incised, except crest and sheltered south slope of cone, which remain scoriaceous. Flow interiors are strikingly slabby, and light-gray slab faces are prominently mottled. Phenocrysts: $0.5-5 \%$ plag (0.5-3 mm); $1-2 \%$ olivine (0.5-1.5 mm); $0.3-2 \%$ opx $(0.5-1.5 \mathrm{~mm}) ; 0.2-1 \% \mathrm{cpx}(0.5-$ $1.5 \mathrm{~mm}$ ); and sparse $\mathrm{Fe}$-Ti oxides; proximally plag-poorer but olivine-richer than distally. Overlies ask lavas, but nonglaciated flow agg ponded against South Butte. K-Ar age: $12 \pm 17$ ka Olivine-bearing pyroxene-andesite $157-60 \%$ $\mathrm{SiO}_{2}$ ) lava flows making up much of the western apron of Mount Adams. Apparently erupted from central vent system that built up the main edifice; unit is a medial-to-distal equivalent of part of proximal cone-forming unit app. Numerous lava flows, individually $10-35 \mathrm{~m}$ thick, form a cumulative apron widely observed to exceed $60 \mathrm{~m}$ in thickness; could locally exceed $100 \mathrm{~m}$ but incision is limited. Everywhere glacially scoured, the lavas are eroded into knobs, benches, and ridges radial to the cone; well exposed proximally but heavily forested distally. Exposures are largely crystalline, massive, slabby or platy, but remnants of basal and marginal vitrophyres and of vesicular flow surfaces are preserved locally. Phenocrysts: 15-25\% plag (0.5-5 mm); $1.5-3 \%$ each $\mathrm{cpx}$ and opx (0.5-1.5 mm); $0.5-3 \%$ olivine (0.5$2 \mathrm{~mm}$ ). Olivine-plag clusters as large as $1 \mathrm{~cm}$ are common; their disaggregation may account for wide range in content of free olivine. Overlies units atf, all, dlr, and brc $(63 \pm 14 \mathrm{ka})$; overlain by abs $(28 \pm 6 \mathrm{ka})$ and atm. Essentially a sectorial subdivision of unit app but age-equivalent to only an early part of it

ask Andesite of Suksdorf Ridge (late Pleistocene)-Olivine-bearing pyroxene-andesite $\left(56.5 \% \mathrm{SiO}_{2}\right)$ lava flows from effusive vents at and near knob 9402 on lower Suksdorf Ridge. Vent areas are marked by linear squeeze-ups, wave-like rolls, and low tumuli, commonly having polygonally jointed, corrugated, or ropy surfaces. A shingled plateau of numerous leveed flows dips southward about $13^{\circ}$, steepening to $23^{\circ}$ adjacent to Crescent Glacier and as far as South Butte. Having been higher than adjacent late Pleistocene glaciers, the surface of this ridgecrest plateau remains blocky, vitrophyric, and vesicular to scoriaceous, although east and west of South Butte the same flow complex was deeply incised by late Pleistocene ice. On each of the 100to $180-\mathrm{m}$-high glaciated scarps adjacent to Crescent, Gotchen, and Mazama Glaciers, 1015 lava flows are exposed, individually 3$20 \mathrm{~m}$ thick; all flows are predominantly rubbly, having massive crystalline interior zones typically only 1-4 m thick. Phenocrysts: $10-25 \%$ (mostly $19-22 \%$ ) plag (0.5$4 \mathrm{~mm}$ ); $2-3 \% \mathrm{cpx}(0.5-1.5 \mathrm{~mm}) ; 2-4 \%$ opx (0.5-1.3 mm); $0.5-1.5 \%$ olivine (mostly smaller than $0.5 \mathrm{~mm}$ ); less than $1 \% \mathrm{Fe}$-Ti oxides (to $0.5 \mathrm{~mm}$ ); and conspicuous clusters involving any combination of these phases. Overlies units app ando awc; overlain by asb and agg. $\mathrm{K}-\mathrm{Ar}$ age: $10 \pm 16 \mathrm{ka}$

Andesite of Snipes Mountain (late Pleistocene)-Sparsely porphyritic olivine-andesite $\left(56 \% \mathrm{SiO}_{2}\right)$ lava flows and cinder-spatter cone, both heavily soil covered. Flows rubbly to distally blocky, forming flow fronts $10-30 \mathrm{~m}$ high. Phenocrysts: $1-2 \%$ plag $(0.5-3 \mathrm{~mm})$; $2-3 \%$ olivine, $2 \% \mathrm{cpx}$, and less than $1 \%$ opx (all smaller than $1 \mathrm{~mm}$ ). Although chemically 
identical to proximal lavas, the flow that extends $8 \mathrm{~km}$ southwest is zoned in phenocryst content, having as much as $8 \%$ plag and only about $1 \%$ olivine distally. Overlain by units aaa, ahg, bsb, and gy moraine; younger than contiguous units $a b b$ and aeb. Undated

Andesite of Salt Creek (middle Pleistocene)-Olivine-bearing pyroxene-andesite $\left(58-59 \% \mathrm{SiO}_{2}\right)$ lava flows forming the $5800^{\prime}$ $(1770 \mathrm{~m})$ rim around the canyon of upper Salt Creek. Source concealed by younger units, presumably to northeast beneath high cone of Mount Adams. Everywhere icescoured, outcrops are 5-10 m thick, mostly crystalline, massive, and platy, but remnants of glassy vesicular carapace survive locally. Phenocrysts: $15 \%$ plag $(0.5-3 \mathrm{~mm}) ; 1 \%$ each olivine and $\mathrm{cpx}(0.5-1.5 \mathrm{~mm}) ; 2.5 \%$ opx $(0.5$ $1.5 \mathrm{~mm}$, rarely to $2.5 \mathrm{~mm}$ ). Lies directly upon unit all ( $329 \pm 11 \mathrm{ka})$, of which it could be a late-erupted variant; overlain by till and debris-avalanche deposits. Undated tocene)-Plagioclase-rich pyroxene-andesite $\left(60 \% \mathrm{SiO}_{2}\right)$ lava flows forming the glacially steepened ridge and distal flow-apron south of Twin Falls Creek, on lower west flank of Mount Adams. Source concealed by much younger lavas that built the present-day high cone. Exposures as thick as $30-50 \mathrm{~m}$ at several places are generally glacially scoured, crystalline, massive, and slabby to platy; columnar lower vitrophyre and remnants of blocky, partly glassy, massive to vesicular carapace survive locally, especially distally. Phenocrysts: $20-25 \%$ plag $(0.5-5 \mathrm{~mm}) ; 1-2 \%$ each of opx and cpx (0.5-2.5 mm). Older than all contiguous Quaternary units; rests on Tertiary andesites. K-Ar age: $137 \pm 6 \mathrm{ka}$, at $3900^{\prime}$ cliff just south of Twin Falls Creek

Andesite of The Island (middle Pleistocene)Plagioclase-rich olivine-pyroxene andesite $(57 \%$ $\mathrm{SiO}_{2}$ ) scoria-cone remnant and lava flows that make up much of the surface of The Island, a partly drift-free plateau between Big Muddy and Hellroaring Creeks. Cone 6365, about $300 \mathrm{~m}$ wide and $40 \mathrm{~m}$ high, consists of lightly agglutinated, oxidized spatter and coarse scoria; its south face and the ridge of slabby crystalline lavas extending $0.8 \mathrm{~km}$ southeast from it were eroded by glacial ice that spilled over the Ridge of Wonders from the northwest. East of the cone, however, ice was confined within the canyon of the Big Muddy, so lavas capping most of the 4-km-long surface of The Island remain blocky, vesicular, and vitrophyric, although mantled with thick loess-rich soil. Phenocrysts: $25-30 \%$ plag $(0.5-4 \mathrm{~mm}) ; 3 \%$ opx, $1 \%$ olivine, and less than $1 \% \mathrm{cpx}$ (all 0.5-1.5 mm). Overlies units ahv and arw. $\mathrm{K}$-Ar age: $385 \pm 7 \mathrm{ka}$ atm

Andesite of Takh Takh Meadow (Holocene) Pyroxene-andesite $\left(59.5-61 \% \mathrm{SiO}_{2}\right.$ ) lava flows forming three major tongues along Adams Creek, Lewis River, and Mutton Creek. From a common source concealed beneath Adams Glacier or its Neoglacial moraines, thick blocky lavas flowed west and north-northwest for more than $10 \mathrm{~km}$. Flow surfaces are rugged, often craggy with prominent levees medially. Exposures are everywhere vitrophyric, with a wide range of vesicularity from nearly massive to scoriaceous. Little-eroded except locally along Adams Creek margin, but primary relief widely exceeds $80 \mathrm{~m}$. Phenocrysts: $30-35 \%$ plag $(0.5-3 \mathrm{~mm}$, a few to $5 \mathrm{~mm}) ; 2 \%$ each cpx and opx (0.5-1.5 mm); less than $1 \%$ $\mathrm{Fe}-\mathrm{Ti}$ oxides $(0.2-0.5 \mathrm{~mm})$; and rare olivine. Younger than all contiguous volcanic units. Proximally overlapped by Neoglacial drift and avalanche debris; debris-flow cover is extensive near Adams Creek. One of youngest eruptive units at Mount Adams; its age is between those of regional ashfall layers with ${ }^{14} \mathrm{C}$ ages of 6.8 (Mazama ash) and $3.5 \mathrm{ka}$ (St. Helens layer $\mathrm{Ye}$ )

awc

Andesite west of Crescent Glacier (late Pleistocene)-Olivine-bearing pyroxene-andesite (58.5-59.5\% $\mathrm{SiO}_{2}$ ) lava flows from effusive vents at and near knob 9090 on lower Suksdorf Ridge. Vent areas are marked by lava mounds, squeeze-ups, and tumuloid features like nearby vents of unit ask. Proximal area is a ridgecrest plateau $1.5 \mathrm{~km}$ long, capped by numerous leveed flows that remain blocky, vitrophyric, and vesicular, having stood higher than adjacent Pleistocene glaciers. Distal tongue and plateau margins, however, are glacially eroded, exposing on 150-m scarps as many as 15 rubbly lava flows, each 3-20 $\mathrm{m}$ thick with massive crystalline internal zones only 1-5 m thick. Phenocrysts: $15-20 \%$ plag $(0.5-3 \mathrm{~mm})$; $2 \% \mathrm{cpx}(0.5-1 \mathrm{~mm}) ; 6 \%$ opx $(0.5-1.5 \mathrm{~mm})$; $0.5 \%$ olivine $(0.5-1.5 \mathrm{~mm})$; less than $1 \% \mathrm{Fe}-$ $\mathrm{Ti}$ oxides (smaller than $0.5 \mathrm{~mm}$ ); and clusters involving any combination of these phases. Overlies unit app ( $13 \pm 8 \mathrm{ka})$; overlain by ask $(10 \pm 16 \mathrm{ka})$

awf Andesite of West Fork (late Pleistocene)Plagioclase-rich pyroxene-andesite (59-60\% $\mathrm{SiO}_{2}$ ) lava flows forming apron north of Little Muddy Creek and an intracanyon tongue along Clearwater Creek and West Fork of Klickitat River. Source concealed beneath younger andesites of units adg or app. Surface everywhere ice-scoured and widely till-covered; intracanyon tongue largely eroded away. Forms knobs, ribs, and benches; rocks mostly crystalline, massive, commonly platy. Phenocrysts: $25 \%$ plag $(0.5-4 \mathrm{~mm}) ; 5 \%$ opx $(0.5-2 \mathrm{~mm})$; 2-3\% cpx (0.5-1.5 mm). Overlies units bts, bwf, and bgb (68 $\pm 10 \mathrm{ka})$; overlain by adg, bsc, and btc. K-Ar age: $55 \pm 7$ ka 

tocene)-Phenocryst-poor olivine-andesite $\left(55.5 \% \mathrm{SiO}_{2}\right)$ lava flow on northeast flank of Mount Adams. Vent concealed by presentday high cone or by Wilson Glacier. Several glacially eroded remnants of a single lava tongue extend northeast from the Neoglacial moraine for about $5 \mathrm{~km}$ along both sides of Little Muddy Creek. Maximum exposed thickness $35 \mathrm{~m}$. Unit is typically crystalline, massive but commonly thinly platy, and everywhere stripped of its glassy carapace. Phenocrysts: $1-3 \%$ olivine (smaller than $1 \mathrm{~mm}$ ), less than $1 \%$ plag (smaller than $1 \mathrm{~mm}$ ), and rare cpx. Overlies unit alm; overlain by bgt $(159 \pm 31 \mathrm{ka})$ and adg. Undated

Andesite west of Muddy Fork (middle Pleistocene)-Plagioclase-rich pyroxene-andesite $\left(59-60 \% \mathrm{SiO}_{2}\right)$ lava flows forming till-covered apron north of Foggy Flat and southeast of Muddy Meadows. Source concealed by younger andesites, presumably beneath present-day cone of Mount Adams. Although surface is everywhere glacially eroded, massive to polygonally jointed, nonvesicular vitrophyre is extensively preserved at 5400'-5600' (1650-1700 m); elsewhere, only crystalline platy interior is exposed. Heavily forested, till- and soil-covered distally. Outliers east and east-southeast of Potato Hill are compositionally similar. Phenocrysts: $15 \%$ plag (0.5-4 mm); $2.5 \%$ each of opx and $\mathrm{cpx}$ (0.5-2 mm); sparse Fe-Ti oxides and (in some flows) sparse olivine. Overlain by units amf and aff. K-Ar age: $328 \pm 21 \mathrm{ka}$

Andesite of White Salmon River (middle Pleistocene)-Plagioclase-rich pyroxene-andesite $\left(57-63 \% \mathrm{SiO}_{2}\right)$ lava flows constituting extensive remnants of the southwest flank of a large dissected stratocone of middle Pleistocene age, apparently once centered somewhere beneath the modern summit cone. Although no significant erosional unconformity is recognized internally, this grouping of varied eruptive units is temporally and compositionally broader than any other unit on the map; subdivision seemed impractical owing to poor continuity of exposure. On walls of Cascade Creek, pile is cumulatively $300 \mathrm{~m}$ thick and typically consists (at any section) of 8-15 lava flows, each 7-25 m thick; more distally, on walls of the White Salmon River gorge, pile is as thick as $170 \mathrm{~m}$ but consists of only a few flows, each typically thicker than $50 \mathrm{~m}$. Lack of dikes and modest general inclination $\left(2^{\circ}-7^{\circ}\right)$ of pile support interpretation as a medial-to-distal, flank-facies lava apron. Exposures are chiefly slabby ledges or cliffs of crystalline nonvesicular andesite, but zones of scoriaceous flow-breccia and massive to polygonally jointed vitrophyre are exposed locally. Phenocrysts: $10-30 \%$ plag $(0.5-4$ $\mathrm{mm}$, rarely to $7 \mathrm{~mm}$ ); $1-7 \%$ opx and $0.3-2 \%$ cpx (both 0.5-1.5 mm); 0.2-0.7\% Fe-Ti oxides (generally smaller than $0.5 \mathrm{~mm}$ ). Glacially excavated at least twice, the andesite pile is incised to its base along Cascade and Salt Creeks and the White Salmon River, resting directly on Tertiary rocks or unit bws. Older than all other contiguous units. K-Ar ages: $457 \pm 11$ ka for basal lava flow in White Salmon River gorge; $456 \pm 8$ ka for basal flow in upper Cascade Creek; $320 \pm 7$ ka for uppermost flow $\sim 1.3 \mathrm{~km}$ east of confluence of Cascade Creek and White Salmon River bah

bbc

bbj
Basalt of Mount Adams Highway (early Pleistocene)-Olivine-basalt (49.5-50\% $\left.\mathrm{SiO}_{2}\right)$ lava flows forming a 2-km-long bench on west side of Klickitat River between Dairy and Bacon Creeks. Banked against an older wall of Columbia River Basalt Group that enclosed an earlier Klickitat drainage; source of poorly exposed lavas making up this $50-$ to $90-\mathrm{m}$ thick valley-filling remnant is unknown. Bench surface is about $160 \mathrm{~m}$ above present river and $100 \mathrm{~m}$ higher than younger intracanyon surface of unit bof $(775 \pm 114 \mathrm{ka})$. Covered by loessic soil and colluvium rich in rounded blocks and corestones; fair exposure on the NE-facing cliffs. Lavas are weathered, weakly vesicular, and diktytaxitic. Phenocrysts: $3-4 \%$, olivine (0.5$2 \mathrm{~mm}$ ), some with spinel inclusions. White groundmass plagioclase conspicuous on weathered surfaces. Overlain by units apc and abc (903 $\pm 13 \mathrm{ka})$. Undated

Basalt of Bear Creek (middle Pleistocene)Olivine-basalt $\left(50-51.5 \% \mathrm{SiO}_{2}\right)$ lava flows and scoria erupted at large but degraded, elongate cinder cone $2 \mathrm{~km}$ southeast of Flattop Mountain, just west of Trout Lake Valley. Heavily soil-covered lava flows extend $3 \mathrm{~km}$ southeast, where much younger bic lavas conceal their further extent. Cumulative thickness greater than $75 \mathrm{~m}$ where incised by Wang Canyon and Bear Creek; flow contacts are poorly exposed, but some flows are thicker than $8 \mathrm{~m}$, internally massive, slabby. Phenocrysts: $6 \%$ olivine $(0.5-1.5 \mathrm{~mm}) ; 0.5 \% \mathrm{cpx}(0.5-$ $1.5 \mathrm{~mm}$ ); $0.5 \%$ plag (smaller than $1 \mathrm{~mm}$ ). Groundmass peppered with conspicuous olivine. Isolated unit rests exclusively on Tertiary rocks. K-Ar ages: $323 \pm 13 \mathrm{ka}$ and $350 \pm 14$ ka for tongues respectively northeast and southwest of Bear Creek

Basalt of Blue Jay Campground (early Pleistocene)-Plagioclase-olivine basalt (51-52\% $\mathrm{SiO}_{2}$ ) lava flows exposed northwest of Glenwood in several windows beneath King Mountain lavas (bkm). Unit extends more than $9 \mathrm{~km}$ southeast from upper Dry Creek (or farther northwest), where source is concealed 
by younger lavas or till. Flows are crystalline, vesicular, weathered, and covered by loessic soil; significantly incised only locally, notably along Dry Creek where maximum relief is $12 \mathrm{~m}$. Phenocrysts: $3-7 \%$ olivine (0.5-1.5 mm); $1-8 \%$ plag $(1-3 \mathrm{~mm}$, rarely to $8 \mathrm{~mm}) ; 1-2 \% \mathrm{cpx}(0.5-1.5 \mathrm{~mm})$; sparse opx; the several flows show a wide range in proportions of phenocrysts. Uppermost flow exposed east of Dry Creek, just below limit of late Pleistocene till, is notably more mafic ( $10 \%$ olivine; $\left.49 \% \mathrm{SiO}_{2}\right)$. Overlies units ads and bgo; overlain by dhd, bkm, and dss; relations with ddc uncertain. $\mathrm{K}-\mathrm{Ar}$ age: $940 \pm 36 \mathrm{ka}$, in proximal window

bbn Basalt of Bacon Creek (middle Pleistocene)Olivine-plagioclase basalt $\left(49-51 \% \mathrm{SiO}_{2}\right)$ lava flow(s) poorly exposed between Bacon and Dry Creeks on southeast flank of Mount Adams. Vent unknown, concealed by younger lavas. Maximum known thickness about $25 \mathrm{~m}$, along Bacon Creek. Mostly holocrystalline above moraine limit but rubbly surface of distal tongue is partly glassy, vesicular, weathered, and mantled with glacial outwash and loessic soil. Secondary minerals common in vesicles. Phenocrysts: $9-10 \%$ plag $(0.5-2 \mathrm{~mm}$, rarely to $4 \mathrm{~mm}$ ), many riddled with conspicuous glass inclusions; $5 \%$ olivine $(0.5-1.5 \mathrm{~mm})$ with iddingsitized rims. Intergrown olivine-plag clusters common, mostly smaller than $0.5 \mathrm{~cm}$, a few to $2 \mathrm{~cm}$. Overlies unit ahv; older than dhd and aes. K-Ar age: $378 \pm 22 \mathrm{ka}$

bbt Basalt of Big Tree knob (middle Pleistocene)-Cpx-bearing olivine-plagioclase basalt $\left(50 \% \mathrm{SiO}_{2}\right)$ lava that forms part of eroded knob 2896, $200 \mathrm{~m}$ southeast of Trout Lake $\mathrm{Big}$ Tree. Knob is not an eruptive center but a drift-veneered kipuka (former nunatak?) composed of units bbt, aha, and abt. Basalt mostly covered by thick soil; outcrops limited to southeast part of knob; mainly weathered, rounded blocks and exfoliating corestones; massive or finely vesicular to diktytaxitic. Phenocrysts: $6 \%$ plag $(0.5-3$ $\mathrm{mm}) ; 2-3 \%$ olivine $(0.5-1.5 \mathrm{~mm})$; and sparse $\mathrm{cpx}$. Groundmass is rich in tiny olivine. May be banked against abt; older than dhg and bew $(329 \pm 50 \mathrm{ka})$. Undated

Basalt of Cakey Butte (middle Pleistocene)Olivine basalt $\left(49.5-51.5 \% \mathrm{SiO}_{2}\right)$ lava flows erupted at Cakey Butte northwest of Trout Lake. Vent remnant is a knob of oxidized agglutinate and sparse cinders that survived glaciation as a nunatak; surrounding lava plateau is everywhere glacially scoured and drift-covered. Lava stack is as thick as $70 \mathrm{~m}$, exposures generally being massive, holocrystalline, fine-grained, and poorly vesicular, the surface having been glacially stripped. Phenocrysts: 5-10\% small olivine $(0.5-1 \mathrm{~mm}$; typically seriate to olivine-peppered groundmass); iddingsite rims common. Plagioclase occurs only as groundmass microlites, which are usually inconspicuous - in contrast to subjacent acb. Younger than contiguous units aws, bfm, and acb; older than bhs, ben, and dcc. K-Ar age: $246 \pm 19 \mathrm{ka}$

bcc Basalt of Cougar Creek (late Pleistocene)Olivine-plagioclase basalt $\left(51-52.5 \% \mathrm{SiO}_{2}\right)$ lava flows extending $7 \mathrm{~km}$ from upper Cougar Creek to junction of Big Muddy Creek with Klickitat River. Source concealed, probably beneath till about $500 \mathrm{~m}$ west of westernmost exposures. Elsewhere unglaciated, flows are rubbly to blocky, vesicular, moderately soil covered, and incised only distally where relief reaches $25 \mathrm{~m}$. Phenocrysts: $8-10 \%$ plag $(0.5-3 \mathrm{~mm}$, rarely $5 \mathrm{~mm}) ; 6 \%$ olivine $(0.5-1.5 \mathrm{~mm})$; sparse $\mathrm{cpx}$; and scattered clusters of one, two, or all three species. Overlies units dnc, adc, and apc $(120 \pm 5 \mathrm{ka})$

bcl Basalt of Clearwater Creek (middle Pleistocene)-Pyroxene-bearing olivine-plagioclase basalt and andesite $\left(52-56 \% \mathrm{SiO}_{2}\right)$ lava flows exposed in four windows on lower northnortheast flank of Mount Adams. Source concealed by younger units; presumably beneath present-day stratocone. All outcrops are glacially eroded and drift mantled; rocks are mostly massive, crystalline, platy to slabby, but glassy vesicular remnants survive locally. Greatest exposed thickness is $\sim 85 \mathrm{~m}$, adjacent to muddy Fork flow (amf). Phenocrysts: 11-12\% plag (0.5-4 mm; some elongate to $8 \mathrm{~mm}) ; 3-6 \%$ olivine $(0.5-1 \mathrm{~mm}) ; 1-2 \% \mathrm{cpx}$ (0.5-2 $\mathrm{mm}) ; 0.5-1 \%$ opx $(0.5-1.5 \mathrm{~mm})$; and sparse $\mathrm{Fe}$-Ti oxides (smaller than $0.5 \mathrm{~mm}$ ). Despite its distribution and compositional range, unit has petrographic and chemical coherence. Older than all contiguous Quaternary units except bem and possibly bla. K-Ar age: $505 \pm 16 \mathrm{ka}$, at Little Muddy Creek where unit rests directly on Columbia River Basalt Group

bcn Basalt north of Cakey Butte (middle Pleistocene)-Plagioclase-rich olivine-basalt $(49 \%$ $\mathrm{SiO}_{2}$ ) lava-flow remnant $1 \mathrm{~km}$ north-northwest of Cakey Butte. Flow is as thick as 25 $\mathrm{m}$ and caps a glacially scoured $0.5-\mathrm{km}^{2}$ plateau. Presumed to have erupted from same (fissural) vent system along northeast rim of Trout Lake Creek as associated lavas of units bcb and bwc. Exposures are crystalline, slightly to nonvesicular, and slabby to platy. Phenocrysts: $20 \%$ plag $(0.5-5 \mathrm{~mm}) ; 6-7 \%$ olivine $(0.5-2 \mathrm{~mm})$; $3 \% \mathrm{cpx}(0.5-3 \mathrm{~mm})$. Overlies units bwc and bcb $(246 \pm 19 \mathrm{ka})$. Undated

bcw Basalt west of Clearwater Creek (late Pleistocene)-Olivine-basalt $\left(49 \% \mathrm{SiO}_{2}\right)$ lava flows forming rugged $1-\mathrm{km}^{2}$ exposure, $2-3 \mathrm{~km}$ north of Glaciate Butte. Source unknown. Glacially sculptured, craggy outcrops, as thick as 
$60 \mathrm{~m}$, are largely massive, crystalline, and nonvesicular. Phenocrysts: $7 \%$ olivine (0.5-1 $\mathrm{mm})$; abundant groundmass olivine and plag. Base not exposed; older than contiguous units bgb, bsc, btc, and amf. K-Ar age: $97 \pm 21 \mathrm{ka}$

bdc

Basalt of Deer Creek (early Pleistocene or Pliocene)-Alkalic olivine-basalt (49.5-51.5\% $\mathrm{SiO}_{2}$ ) lava-flow remnants on both sides of Klickitat River, near its confluence with Dairy Creek. Source probably east of the area mapped. Base of west-bank remnant rests on a rim of Columbia River Basalt Group $150 \mathrm{~m}$ above present river level, suggesting that bdc lavas either filled or predated establishment of Klickitat River canyon. Lavas are massive or sparsely vesicular, deeply weathered and eroded, covered by thick loessic soil and colluvium containing rounded corestones; poorly exposed except where columnar interior crops out in a landslide headwall on west rim. Phenocrysts: $3 \%$ olivine $(0.5-1.5 \mathrm{~mm})$ seriate to abundant groundmass olivine; $0.5 \%$ each of plag and cpx (both 0.5-1 mm). Probably older than contiguous units bjb and bah, but relations are uncertain. Undated

bds Basalt south of Draper Springs (late or middle Pleistocene)-Cpx-rich olivine-plagioclase basalt $\left(51.5 \% \mathrm{SiO}_{2}\right)$ lava flow, beneath and probably related to unit bdw. Loess-mantled subdued morphology and textures similar to bdw; distinguished principally by conspicuous $\mathrm{cpx}$. Phenocrysts: $5 \% \mathrm{plag}$ (0.5-2.5 mm); $6 \%$ olivine $(0.5-1.5 \mathrm{~mm}) ; 8 \%$ cpx $(0.25-1 \mathrm{~mm})$. Groundmass contains abundant tiny $\mathrm{Fe}$ - $\mathrm{Ti}$ oxides and plag laths. Overlies unit bgo; overlain by bmb and bdw $(122 \pm 21 \mathrm{ka})$. Flow may be slightly earlier, $\mathrm{MgO}$-richer variant of more extensive unit bdw. Undated

bdw Basalt west of Draper Springs (late or middle Pleistocene)-Plagioclase-rich olivine basalt $\left(52-53 \% \mathrm{SiO}_{2}\right)$ lava flows, apparently representing early eruptive phases of King Mountain shield. Vent and much of the lava field are covered by younger lavas of unit bkm derived from vents at present shield summit. Flows are loess mantled, rubbly, poorly exposed, none known to be thicker than $7 \mathrm{~m}$; mostly holocrystalline, not diktytaxitic; ubiquitous irregular to amoeboid vesicles commonly lined with secondary minerals. As there is little incision, cumulative thickness is unknown; relief locally reaches $25 \mathrm{~m}$. Phenocrysts: $10-20 \%$ plag (1-5 mm), typically elongate; $1-2 \%$ olivine (1-3 mm); $2 \%$ cpx (0.5-2 mm); $1-1.5 \%$ opx $(0.5-2 \mathrm{~mm})$. Younger than units bgo, brb, and bds (which may be a related, slightly older variant). Overlain by $\mathrm{bmb}$ and $\mathrm{bkm}$. K-Ar age: $184 \pm 30 \mathrm{ka}$ for window at southwest toe of King Mountain shield; $122 \pm 21$ ka for flow wrapping east side of Red Butte

bem Basalt east of Muddy Fork (middle ? Pleistocene)-Phenocryst-poor olivine-basalt $(50 \%$ $\mathrm{SiO}_{2}$ ) lava flow(s) exposed only locally at eastern margin of Muddy Fork flow complex (amf). Isolated $0.08-\mathrm{km}^{2}$ outcrop was glacially scoured and was once stream-incised; remnant now has about $40 \mathrm{~m}$ local relief. Source unknown; chemically and petrographically unlike any unit in the sector. Rock is dark gray, finely crystalline, and intricately jointed, disintegrating into chunky-to-flaky scree. Phenocrysts: $1 \%$ olivine $(0.5-1.5 \mathrm{~mm})$; sparse tiny plag (rarely $0.5 \mathrm{~mm}$ ). Contains stringers of quartz and feldspar xenocrysts disaggregated from partially melted fragments of adjacent rhyolite unit Trc. Underlies unit amf and appears to underlie units bla and bcl $(505 \pm 16 \mathrm{ka})$. Undated

bew Basalt east of White Salmon River (middle Pleistocene)-Cpx-bearing olivine-basalt (51$53 \% \mathrm{SiO}_{2}$ ) lava flows east of White Salmon River near triple junction of Skamania, Yakima, and Klickitat Counties. Maximum known thickness $40 \mathrm{~m}$; individual flows are poorly exposed and 5-20 m thick. Vent unknown, covered by younger units on south flank of Mount Adams. Flow surfaces weathered, soilcovered, mostly scoriaceous, and mantled with rubbly colluvium, alluvial gravels, and till (go). Most exposures are vesicular, many are diktytaxitic, and (where glacially scoured) some are massive. Vesicles are commonly amoeboid and contain secondary minerals. Phenocrysts: $3-5 \%$ olivine $(0.5-1.5 \mathrm{~mm})$; less than $0.5 \% \mathrm{cpx}(0.5-1 \mathrm{~mm})$. Plagioclase rarely exceeds $0.5 \mathrm{~mm}$; largely restricted to groundmass, where abundant microlites are conspicuous in weathered rocks. Overlies units acb, dhg, and aws; also appears to wrap around knobs composed of units abt and aha. Older than go, ahg, amc, dcc, and bhb. K-Ar age: $329 \pm 50 \mathrm{ka}$

bfm Basalt of Flattop Mountain (middle Pleistocene)-Olivine-basalt $\left(49-51 \% \mathrm{SiO}_{2}\right)$ scoria, agglutinate, and spatter-fed lava flows erupted at Flattop Mountain and an unnamed, similar, cinder-spatter cone $500 \mathrm{~m}$ north of it. Cones are loess mantled, poorly exposed. Thin spatter-fed flows on medial flanks are rubbly and scoriaceous; massive interiors of thicker flows on lower flanks crop out where glacially eroded along southwest wall of Trout Lake Creek. Phenocrysts: $8-12 \%$ olivine (0.5-1 $\mathrm{mm}$; rarely to $2 \mathrm{~mm}$ ), some in clusters; plagioclase restricted to groundmass. Summit cinders of the northern cone are similar looking but chemically more primitive $\left(48.5 \% \mathrm{SiO}_{2}\right)$. Older than unit bcb but younger than bnd; probably younger than 
adjacent cone anp, but relations are equivocal. $\mathrm{K}-\mathrm{Ar}$ age: $394 \pm 12 \mathrm{ka}$

bgb Basalt of Glaciate Butte (late Pleistocene)Olivine-basalt and olivine-plagioclase-basalt (51$52.5 \% \mathrm{SiO}_{2}$ ) lava flows and ejecta erupted at Glaciate Butte, a small cinder-and-spatter cone. Flows extend as far as $25 \mathrm{~km}$ from source, confined along courses of Clearwater Creek and Klickitat River. Proximal lava apron is glacially scoured and has more than $30 \mathrm{~m}$ local relief; glaciated remnants along Clearwater Creek are locally columnar; distal tongue along Klickitat gorge is $10-70 \mathrm{~m}$ thick, incised, but not glaciated. Exposed rocks are mostly massive, crystalline. Armored by agglutinate, till, and minor summit-extruded lava, the cinder cone survived glaciation as a nunatak. Phenocrysts: On cone, $3-5 \%$ olivine (smaller than $1 \mathrm{~mm}$ ); less than $0.5 \%$ each of plag, opx, and $\mathrm{cpx}$ (all $<1 \mathrm{~mm})$. Distally, $3 \%$ olivine (0.5-2 $\mathrm{mm})$, commonly in clusters; $10-20 \%$ plag $(0.5-5 \mathrm{~mm}) ; 7 \% \mathrm{cpx}(0.5-1.5 \mathrm{~mm})$. Younger than contiguous bkr, bcw, and bcl; overlain by btc, bsc, and awf. K-Ar ages: $69 \pm 15$ ka (cone); $68 \pm 10$ ka (Klickitat River)

bgo Basalt of Glenwood (early Pleistocene or Pliocene)-Low-K olivine-basalt $\left(48-50 \% \mathrm{SiO}_{2}\right)$ lava flows along northwest margin of Camas Prairie-Glenwood valley. Source vent(s) probably to northwest, concealed by younger units. Flows are thin, rubbly, vesicular and diktytaxitic; little-eroded but weathered and extensively mantled by loess and alluvium. Phenocrysts: $3-5 \%$ olivine $(0.5-1 \mathrm{~mm}) ; 8 \%$ plag $(0.5-1 \mathrm{~mm})$. Plagioclase conspicuous in groundmass, especially when weathered. Older than all contiguous Quaternary volcanic units, including bbj $(940 \pm 36 \mathrm{ka})$. K-Ar age: $2.36 \pm 0.72 \mathrm{Ma}$ (?)

bgt Basalt of Goat Butte (middle Pleistocene)Cpx-bearing olivine-basalt $\left(50-52.5 \% \mathrm{SiO}_{2}\right)$ lava flows, agglutinate, and scoria erupted at Goat Butte on east flank of Mount Adams. Lava-flow apron that extends eastward $7 \mathrm{~km}$ from vent is widely glaciated but nowhere deeply incised; it is thicker than $90 \mathrm{~m}$ at the set of benches $2 \mathrm{~km}$ north of the butte. Vent complex is a glacially dissected cinder-andspatter cone with more than $250 \mathrm{~m}$ surviving relief, extensively agglutinated and cut by a well-exposed comagmatic dike 3-4 m thick. Stratified ejecta are oxidized brick red high on the butte, but permeable layers making up much of south flank are strikingly yellowish orange, indurated, and castellate, having been lightly altered fumarolically (kaolinite-alunite-montmorillonite-goethite). Phenocryst content unusually variable: $5-10 \%$ olivine $(0.5-3 \mathrm{~mm}$ ), $1-4 \% \mathrm{cpx}$ (as large as $2 \mathrm{~mm}$ ), and $1-5 \%$ plag (1-3 mm). Mulligan Butte is a comagmatic flank vent (see bmg).
Unit bgt is younger than ahv, awg, alm, and $\mathrm{d} / \mathrm{m}$; probably younger than aht; and older than adg and acn (the vent of which is high on Goat Butte). K-Ar age: 159 31 ka

bgu Basalt of Guler Mountain (late or middle Pleistocene)-Olivine-basalt $\left(49 \% \mathrm{SiO}_{2}\right)$ lava flows and cinder cone erupted on ridgecrest south of Trout Lake Valley. Numerous shingled lavas, thin, rubbly, and pervasively vesicular, were mostly diverted into an eastern apron by enclosing ridges. Eastern toe of apron is incised by White Salmon River and the northwest lava tongue by a fork of Cave Creek; otherwise little eroded. Lavas are heavily covered with loessic soil and colluvium, as is the poorly exposed cinder cone and its $150-\mathrm{m}$-wide summit depression. Phenocrysts: $7-8 \%$ olivine $10.5-1 \mathrm{~mm}$, rarely larger); $3-4 \%$ plag $(0.5-1 \mathrm{~mm})$, and there can be $\sim 3 \%$ small $(0.5 \mathrm{~mm})$ plag laths, mostly in 1-2 $\mathrm{mm}$ clusters with olivine. Much older than adjacent unit bic. Undated

bhb Basalt of Herions Bridge (middle Pleistocene)-Sparsely porphyritic olivine-plagioclase basalt $\left(50-51 \% \mathrm{SiO}_{2}\right)$ lava flows at northeast margin of Trout Lake Valley. Source probably lies to the northeast, but vent and all but distal $3.5 \mathrm{~km}$ of lava apron are concealed by younger units. Numerous flows are each 2-6 m thick, giving a cumulative exposed thickness of $25-30 \mathrm{~m}$ in bluffs along White Salmon River; thicker than $60 \mathrm{~m}$ in nearby drill holes (Jones, 1960). Part of unit is glacially scoured and drift mantled, but distal $2 \mathrm{~km}$ (beyond the drift limit) still has a rubbly scoriaceous surface preserved beneath a cover of loessic soil. Exposures are generally weathered, crystalline, and open textured (weakly diktytaxitic). Phenocrysts: $3-5 \%$ plag (0.5$4 \mathrm{~mm}$ ); $0.5 \%$ olivine $(0.5-1 \mathrm{~mm})$. Groundmass plagioclase abundant, conspicuous when weathered. Older than all contiguous volcanic units except agc. K-Ar age: $209 \pm 21 \mathrm{ka}$; similar ages are given by Hammond and Korosec (1983)

bhc Basalt of Holmes Creek (middle Pleistocene)-Plagioclase-olivine basalt $\left(49 \% \mathrm{SiO}_{2}\right)$ lava flows and degraded cinder cone, atop ridge enclosing southeast end of Trout Lake Valley. Flows not strongly eroded but deeply weathered and soil covered; best exposed at southeast margins. Phenocrysts: $5 \%$ olivine $(0.5-2 \mathrm{~mm})$ and $3-4 \%$ plag $(0.5-1 \mathrm{~mm})$. Rests exclusively on Columbia River Basalt Group; unit ams $(622 \pm 15 \mathrm{ka})$ is banked against it. Undated

bhs Basalt south of Haystack Butte (late or middle Pleistocene)-Cpx-bearing olivine-plagioclase basalt $\left(51-52.5 \% \mathrm{SiO}_{2}\right)$ intracanyon lava-flow remnants on south wall and floor of Trout Lake Creek, near and downstream from its 
confluence with Little Goose Creek. Source unknown, probably in Indian Heaven volcanic field west of map area. Upstream remnants are cliff forming and as thick as $90 \mathrm{~m}$; downstream remnants are subdued benches and knobs with more than $15 \mathrm{~m}$ relief on present-day canyon floor. Exposures are glacially eroded, finely crystalline, sparsely to nonvesicular, typically massive, but locally columnar jointed near base. Phenocrysts: $20-22 \%$ plag (0.5-3.5 mm, uncommonly to $5 \mathrm{~mm}) ; 4 \%$ olivine $(0.5-3 \mathrm{~mm}) ; 1-2 \% \mathrm{cpx}$ (prisms to 3 $\mathrm{mm}$ long). Overlies or banks against all contiguous volcanic units-except the still-younger intracanyon tongues of units blg and bic. Undated, but postdates glacial incision of acb and bcb $(246 \pm 29 \mathrm{ka})$

Basalt of Ice Caves (late Pleistocene)-Low$\mathrm{K}$ olivine-plagioclase basalt $\left(48-49 \% \mathrm{SiO}_{2}\right)$ lava flows filling extensive lowlands west and south of the Trout Lake Valley. Erupted in Indian Heaven volcanic field from Lemei Rock shield (Hammond, 1980), $5 \mathrm{~km}$ west of map edge. Numerous fluid lavas, typically less than 1 to 5 $\mathrm{m}$ thick, flowed eastward, then southward, as far as $43 \mathrm{~km}$ to Husum; two lava tongues also spread $13 \mathrm{~km}$ northeast into Trout Lake Creek. Maximum known total thickness $25 \mathrm{~m}$, along gorge of White Salmon River. Unit displays pahoehoe surfaces, blocky mosaic jointing, and numerous tumuli and lava tubes (Halliday, 1963), some tubes having passages 5-20 m high. Although unit is widely forest covered, loessic soil is generally thin and locally absent. Incised by a few major streams but otherwise little-eroded; glacially modified only on source shield. Lavas are diktytaxitic, largely holocrystalline, and pervasively vesicular. Phenocrysts: $5-10 \%$ olivine $(0.5-2 \mathrm{~mm})$; and $10-30 \%$ plag $(0.5-8 \mathrm{~mm})$, commonly in thin laths or clusters of radiating laths. Groundmass plag (and olivine) always abundant, but size and abundance of plag phenocrysts are highly variable. Younger than all contiguous volcanic units, but see description of unit blc. ${ }^{14} \mathrm{C}$ age: $22.1 \pm 0.3$ ka for organic-rich black soil directly beneath the lava, near Mile 18.5 of White Salmon River

Basalt of Jungle Butte (early Pleistocene or Pliocene)-Olivine-basalt $\left(52 \% \mathrm{SiO}_{2}\right)$ lava flows of 6-km-wide Jungle Butte shield, partly on east edge of map. Cumulative thickness as much as $180 \mathrm{~m}$ atop east wall of Klickitat River canyon. Flows are numerous but poorly exposed, deeply weathered, covered by thick loessic soil and rubbly colluvium with rounded corestones. Holocrystalline, massive or vesicular, not diktytaxitic. Phenocrysts: $16 \%$ olivine $(0.5-3 \mathrm{~mm})$; plag conspicuous in groundmass, especially in weathered rocks,

but only rarely larger than $0.5 \mathrm{~mm}$. Unit rests on Columbia River Basalt Group

bkm

bla

blc

\section{Basa} southwest corner of area mapped. Erupted in Indian Heaven volcanic field from Lemei Rock shield (Hammond and Korosec, 1983), $5 \mathrm{~km}$ west of map edge. Emplaced radially around shield, with the tongue shown here extending at least $18 \mathrm{~km}$ eastward to Cave Creek; probably extends about $4 \mathrm{~km}$ farther beneath lavas of unit bic to Trout Lake area (Jones, 1960). Tongue consists of numerous shingled flows, many thinner than $1 \mathrm{~m}$, characterized by pahoehoe surfaces, blocky cooling joints, tumuli, and lava tubes. Pervasively vesicular and diktytaxitic. Little incision, but modest soil cover subdues surfaces more than those of adjacent unit bic. Local relief typically slight but as great as $15 \mathrm{~m}$ near Beaver Creek flow front; stack of thin flows is thicker 
than $20 \mathrm{~m}$ at Big Trench lava tube. Phenocrysts: $5-8 \%$ olivine $(0.5-4 \mathrm{~mm})$, commonly clustered and containing spinel inclusions; plagioclase conspicuous in groundmass but only rarely larger than $0.5 \mathrm{~mm}$. Plagioclase commonly encloses or clusters with tiny olivines. Overlain by unit bic. From the same eruptive center, successive units blc and bic are easily distinguished in most places by abundance and form of phenocrysts, but locally (or in some flows) the distinction blurs. Similarly, bic is typically poorer in $\mathrm{Si}, \mathrm{Mg}, \mathrm{Ti}, \mathrm{K}$, and $\mathrm{P}$, and richer in $\mathrm{Al}$ and $\mathrm{Fe}$, but chemical overlap of mineralogically distinct lava types has been recognized locally. ${ }^{14} \mathrm{C}$ ages: 28-31 ka (P.E. Hammond, unpubl. data, 1984)

Basalt at the confluence of Little Goose and Trout Lake Creeks (middle or late Pleistocene)-Shoshonitic, cpx-olivine basalt $\left(52.5 \% \mathrm{SiO}_{2}\right)$ intracanyon lava-flow remnants forming benches as high as $85 \mathrm{~m}$ above river level in all 3 sectors at confluence. Source unknown, probably in Indian Heaven volcanic field west of map area. Cliff-forming exposures are as thick as $75 \mathrm{~m}$, largely massive, crystalline, finely vesicular, and either light to medium gray or slightly oxidized, $\tan$ to pale violet. Phenocrysts: $5-7 \%$ olivine $(0.5-$ $1.5 \mathrm{~mm})$, seriate to olivine-rich groundmass; $4-5 \% \mathrm{cpx}(0.5-2 \mathrm{~mm})$. Overlies or banks against all contiguous volcanic units except still-younger intracanyon tongue of bic. Undated, but younger than dated unit bcb $(246 \pm 19$ ka)

blm Basalt of Little Mountain (middle? Pleistocene)- Low-K phenocryst-poor plagioclaseolivine basalt $\left(49 \% \mathrm{SiO}_{2}\right)$ scoriae of Little Mountain cinder cone on floor of Trout Lake Valley. No lavas exposed. Loess-covered 80 - $\mathrm{m}$-high cone has sparse patches of scoria-rich colluvium but no true exposures. Scoria blocks range from almost aphyric to having $1-2 \%$ each of olivine and plagioclase phenocrysts (both smaller than $1 \mathrm{~mm}$ ); a snowstorm groundmass conspicuous in weathered blocks is imparted by abundant plag microlites, sometimes concentrated in 1-mm mottles. The isolated cone is surrounded by lava flows of much younger unit bic and by surficial deposits. Undated

blr

Basalt of Laurel (middle Pleistocene)-Plagioclase-olivine basalt $\left(50 \% \mathrm{SiO}_{2}\right)$ lava flows and degraded cinder cone, just west of site of Laurel. Deeply weathered, loess-covered, and poorly exposed except at cinder quarry. Phenocrysts: $5 \%$ olivine $(0.5-1.5 \mathrm{~mm})$ and 2-4\% plag (0.5-1.5 $\mathrm{mm})$; groundmass plag laths locally conspicuous. Rests on Columbia River Basalt Group and banks against unit alr $(631 \pm 21 \mathrm{ka})$. Undated bmb Basalt of Meadow Butte (late Pleistocene)Olivine basalt $\left(50-51 \% \mathrm{SiO}_{2}\right)$ lava flows and scoria of the 4- by 12-km Meadow Butte shield, south of King Mountain. Shield is capped by a small cinder cone. Numerous shingled flows are mostly 1-4 m thick, rubbly, and covered by loessic soil; wide textural range from glassy and vesicular to crystalline and diktytaxitic. Phenocrysts: $5-10 \%$ olivine $(0.5-1.5 \mathrm{~mm})$ and rare plagioclase $(0.5-1 \mathrm{~mm})$; no cpx. Variable development of microlitic plagioclase $(0.1-0.3 \mathrm{~mm})$ in groundmass. Hard to distinguish from bkm flows, which tend to have a little $\mathrm{cpx}$, more and slightly larger olivine, and more and larger olivine clusters. Younger than all contiguous volcanic units except bkm (106 $\pm 25 \mathrm{ka})$ and bsb. K-Ar age: $138 \pm 58 \mathrm{ka}$, on east slope; southerly bmb lavas overlie bqb lava dated at $115 \pm 28 \mathrm{ka}$

bmg Basalt of Mulligan Butte (middle Pleistocene)-Cpx-bearing olivine-basalt $(52.5 \%$ $\mathrm{SiO}_{2}$ ) cinder-and-spatter cone on northeast flank of Goat Butte center (bgt), for which it is a comagmatic subsidiary vent. Cone is degraded and soil covered but not significantly modified glacially; appears to overlie some Goat Butte lava flows and to be wrapped by younger ones. Phenocrysts: $7 \%$ olivine (0.5$2 \mathrm{~mm}$ ), $1 \% \mathrm{cpx}$ (to $1 \mathrm{~mm}$ ), and $1 \%$ plag (1$3 \mathrm{~mm}$ ). Undated; contemporaneous with bgt $(159 \pm 31 \mathrm{ka})$, to which it is similar chemically and mineralogically

bms Basalt of McCumber Spring (middle Pleistocene)-Olivine-plagioclase basalt (49-50\% $\mathrm{SiO}_{2}$ ) lava flow(s) at north edge of the Glenwood valley. From unknown vent concealed by younger lavas, flowed southeast to Klickitat River. Loess-mantled, poorly exposed, with generally low relief; mostly holocrystalline, weathered, and rich in vesicles commonly lined with secondary minerals. Phenocrysts: 11$15 \%$ plag $(0.5-3 \mathrm{~mm}) ; 5-8 \%$ olivine $(0.5-2$ $\mathrm{mm}$ ) with iddingsite rims; and $1-2 \% \mathrm{cpx}$ $(0.5-1.5 \mathrm{~mm})$. Younger than units bgo, aah, and bof; overlain by dhd (at McCumber Spring) and ddc. Undated but bracketed by bof $(775 \pm 114 \mathrm{ka})$ and ddc $(694 \pm 8 \mathrm{ka})$

bnd

Basalt north of Deadhorse Meadow (middle Pleistocene)-Olivine-basalt (49.5-50.5\% $\mathrm{SiO}_{2}$ ) lava flows that once formed an extensive surface now dissected by Smoky, Little Goose, and Trout Lake Creeks. Source unknown; probably to west in Indian Heaven volcanic field. Glacially scoured lavas crop out as rounded knobs and slabby ledges, extensively mantled by drift, loessic soil, and rubbly colluvium rich in variably rounded slabs and blocks. Most exposures are light to medium gray (weathering ochre), finely crystalline, and weakly or nonvesicular; sparse vesicular ex- 
posures are generally oxidized. Unit may be as thick as $60 \mathrm{~m}$ south of Trout Lake Creek where poorly exposed. Phenocrysts: $5-8 \%$ olivine $(0.5-3 \mathrm{~mm})$, typically seriate to olivine-rich groundmass; less than $1 \%$ plag $(0.5$ $1 \mathrm{~mm}$ ). Overlies Tertiary rocks and unit bsk; apparently older than all other contiguous Quaternary units, including bfm ( $394 \pm 12 \mathrm{ka})$. Undated

bnf Basalts west of Ninefoot Creek (middle Pleistocene)-Olivine-basalt $\left(48-52 \% \mathrm{SiO}_{2}\right)$ scoria, agglutinate, dikes, and thin lava flows that erupted from a chain of vents along divide between Ninefoot and Trout Lake Creeks. In part fissure-aligned, the cinder-spatter centers are severely eroded, some largely removed. Proximal stacks of spatter-fed lavas $0.5-2 \mathrm{~m}$ thick are vesicular, oxidized, and rich in scoriaceous rubble. Stripped from steeper east slope, lava-flow remnants on west and south slopes are crystalline, massive, slabby, and poorly exposed through thick loess-rich colluvium; lower slope of largest remnant is tillmantled. Phenocrysts: $4-10 \%$ olivine $(0.51 .5 \mathrm{~mm})$; cpx ranges widely from $0-2 \%$; $0-0.5 \%$ plag $(0.5-1 \mathrm{~mm})$; plag largely restricted to groundmass. Isolated remnants rest exclusively on Tertiary rocks. Undated

bof Basalt of Outlet Falls (early or middle Pleistocene)-Low-K olivine-basalt $\left(48-50 \% \mathrm{SiO}_{2}\right)$ lava flows along Klickitat River and beneath parts of Camas Prairie. Numerous stacked flows, mostly 1-5 m thick, with a cumulative thickness reaching $100-160 \mathrm{~m}$ on walls of Klickitat River canyon. Vent unknown, probably to west, concealed by younger units. Intracanyon remnants extend down Klickitat River as far as $23 \mathrm{~km}$ southeast of map edge (Sheppard, 1967a). Chemically distinct from similar lavas of unit bgo along northwest edge of Camas Prairie. Diktytaxitic, vesicular, and holocrystalline, although thicker flows have massive interiors. Commonly has polygonal blocky-mosaic jointing. Phenocrysts: 2-5\% olivine (0.5-1.5 mm), commonly in clusters; some flows have sparse $0.5-1 \mathrm{~mm}$ plag, but plag is generally confined to groundmass. Younger than units aah, bah, abc, and bdc; overlain by bms, apc, and probably aqb. K-Ar age: $775 \pm 114 \mathrm{ka}$

bph

Basalt of Potato Hill (late Pleistocene)Olivine-plagioclase basalt and andesite (50$54 \% \mathrm{SiO}_{2}$ ) lava flows and scoria erupted at prominent $180-\mathrm{m}$-high Potato Hill cinder cone, $1.1 \mathrm{~km}$ in diameter. A few flows went northeast, but most spread westward into the Cispus valley, extending at least $15 \mathrm{~km}$ from vent. Proximally (between Midway Creek and Muddy Fork), flows are rubbly and vesicular, loess covered, unglaciated, and little incised; but they are drift covered and fluvially

incised distally along Cispus River, which downstream from junction of Adams Creek has cut a gorge deeper than $30 \mathrm{~m}$ through the unit. Cinder cone is degraded, soil covered, but scarcely eroded. Phenocrysts: Somewhat variable: $3-8 \%$ olivine $(0.5-3 \mathrm{~mm})$; $5-12 \%$ plag $(0.5-4 \mathrm{~mm})$; and sparse to as much as $3 \% \mathrm{cpx}(0.5-2 \mathrm{~mm})$. Older than contiguous unit bsc. K-Ar age: $111 \pm 10 \mathrm{ka}$

bpr

$b q b$
Basalt of Peterson Ridge (middle? Pleistocene)-Sparsely porphyritic olivine-basalt $\left(52 \% \mathrm{SiO}_{2}\right)$ lava flow(s) banked against south end of Peterson Ridge, near southwest corner of map. Vent unknown, apparently not local; probably west of map area. Unit is everywhere glacially eroded, covered with coarse colluvial rubble, till, and loessic soil; sparse exposures are massive with slabby jointing. Relief of more than $60 \mathrm{~m}$ partly reflects draping over a shoulder of Tertiary rocks. Phenocrysts: $1-2 \%$ olivine $(0.5-2 \mathrm{~mm})$ in light- to medium-gray aphanitic matrix; less than $0.5 \%$ each anhedral opx and cpx (both smaller than $1 \mathrm{~mm}$ ). Much older than adjacent unit bic. Undated

qb Basalt of Quigley Butte (late Pleistocene)Olivine-basalt $\left(51 \% \mathrm{SiO}_{2}\right)$ lava flows and scoria of the 4- by 6-km Quigley Butte shield, west of Camas Prairie. Capping cinder cone has a shallow 300-m-wide crater. Numerous shingled flows are mostly 1-4 m thick, rubbly, vesicular, and loess mantled but little eroded. Quarry at $700 \mathrm{~m}(2280)$ elevation on southeast flank exposes $5 \mathrm{~m}$ of stratified cinders, probably related to a subsidiary vent buried by lavas from the main summit vent. Phenocrysts: 5$7 \%$ olivine (0.5-1.5 mm); no plag phenocrysts, but plag microlites (to $0.25 \mathrm{~mm}$ ) are common; uncommon fragments of $\mathrm{cpx}$ (and some olivine) are probably xenocrystic. Younger than alr, ams, and aqb, which consists of plagrich, earlier products of same shield. Overlain by bmb lavas. K-Ar age: $115 \pm 28 \mathrm{ka}$

Basalt of Red Butte (middle Pleistocene)Plagioclase-rich olivine basalt $\left(49 \% \mathrm{SiO}_{2}\right)$ scoria and dikes of Red Butte cinder cone, southeast of King Mountain. No lava flows exposed. Stratified cinders are oxidized, nonagglutinated, and covered by thick loessic soil. Quarry walls expose comagmatic dikes, 0.1-1 m thick, cutting cinders. Phenocrysts: $15-20 \%$ plag $(0.5-5 \mathrm{~mm})$; less than $1 \%$ each of olivine and $\mathrm{cpx}(0.5-1.5 \mathrm{~mm})$. Chemically similar dikes are relatively richer in olivine but poorer in cpx and plag. Cone is wrapped by successively younger lava flows of units bdw, bmb, and bkm. Undated but older than

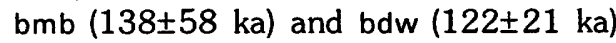

c Basalt of Riley Creek (late Pleistocene)Cpx-bearing olivine-plagioclase basalt (51.5$52.5 \% \mathrm{SiO}_{2}$ ) lava flows on west flank of Mount 
Adams. Source concealed by Pinnacle Glacier or present-day cone of Mount Adams; an unusually thick $(50 \mathrm{~m})$ flow exposed beneath Pinnacle Glacier moraine may reflect proximity to vent and (or) may have been iceponded. Most flows are 1-10 m thick, rubbly, vesicular to scoriaceous, with massive crystalline interiors; columnar jointed along lowermost Riley Creek. Some flows extended farther than $7 \mathrm{~km}$ westward; a few probably entered Lewis River, from which they were subsequently eroded. Phenocrysts: 5-10\% olivine $(0.5-2 \mathrm{~mm}), 5-10 \%$ plagioclase (mostly smaller than $2 \mathrm{~mm}$, rarely to $5 \mathrm{~mm}$ ); $2-3 \%$ cpx $(0.5-2.5 \mathrm{~mm})$; variability in phenocryst content contrasts with narrow chemical range. Older than contiguous Quaternary volcanic units except dlr, arc and atf; distally rests on Tertiary rocks, but base is not exposed proximally or medially. K-Ar age: $63 \pm 14 \mathrm{ka}$

bsb Basalt of Smith Butte (late Pleistocene)Alkalic olivine-basalt $\left(48-49.5 \% \mathrm{SiO}_{2}\right)$ lava flows and four cinder-spatter cones west of King Mountain. Numerous thin (slightly ne-normative) flows form a 4-km-wide apron that distributes distally into three valley-confined tongues; one of which extends $10 \mathrm{~km}$ from vent. The three contiguous northern vents are aligned north-south and probably co-erupted along a common fissure; the southern cone is separate, slightly younger, chemically more primitive, and fed the southeast lava tongue. Flows are rubbly, scoriaceous, internally crystalline but pervasively vesicular, and mostly 1-7 $\mathrm{m}$ thick. Rugged primary surfaces are little incised; local relief is modest but reaches $20 \mathrm{~m}$ at some flow fronts. Forest cover is heavy, but loessic soil is generally thin. Phenocrysts: $5-9 \%$ olivine $(0.5-1.5 \mathrm{~mm})$, some with spinel inclusions; plagioclase restricted to groundmass; sparse cpx and 4-10 $\mathrm{mm}$ olivine may be xenocrystic. Younger than all contiguous volcanic units. K-Ar age: $14 \pm 13 \mathrm{ka}$

bsc Basalt of Spring Creek (late Pleistocene)Low-K olivine-basalt $\left(47-49 \% \mathrm{SiO}_{2}\right)$ lava flows erupted at low shield (knob 5162) about 1.5 $\mathrm{km}$ southeast of Potato Hill; shield is capped by a steeper swell $(0.6 \mathrm{~km}$ across) that has a shallow 120 -m-wide crater rimmed by effusive lavas, minor agglutinate, and sparse oxidized cinders. From this vent on the Klickitat-Cispus drainage divide, numerous thin (1-5 $\mathrm{m}$ ) flows spread as far as $18 \mathrm{~km}$ eastward and at least $35 \mathrm{~km}$ westward. Flows are rubbly, scoriaceous, commonly with blocky mosaic jointing. Vent area of shield not glaciated, but medial and distal lavas are widely scoured and drift-mantled; overlain by late Wisconsin moraine near Clearwater Creek. Modest incision except along Cispus River, where 25-40 m gorge exposures are common. Lavas are typically holocrystalline or partly glassy, diktytaxitic, and sparsely to coarsely vesicular. Map unit includes diamicton (pattern), which is poorly exposed except in streambanks of Muddy Fork and in a few roadcuts; consists principally of ground moraine and probable debris-flow deposits, in both of which nearly all clasts are bsc. Phenocrysts: $1-8 \%$ olivine $(0.5-2 \mathrm{~mm}$, rarely $3 \mathrm{~mm})$, some of it in clusters, commonly with spinel inclusions and iddingsite rims. In some flows, olivine is seriate from 0.1-1 mm. Plagioclase and cpx are usually restricted to the groundmass, but some lavas have $1 \%$ plag $(0.5-1 \mathrm{~mm}$, rarely $2 \mathrm{~mm})$ and a trace of $\mathrm{cpx}(0.5 \mathrm{~mm})$. Sparse nearvent cinders $(1-6 \mathrm{~cm})$ include some having phenocrysts only of olivine and others additionally containing about $10 \%$ plag and $3 \% \mathrm{cpx}$; the latter assemblage is not seen in bsc lavas. Younger than all contiguous volcanic units except btc and amf. ${ }^{14} \mathrm{C}$ age: $21.5 \pm 0.5 \mathrm{ka}$ for dark-brown organic-rich soil directly beneath lava along Cispus River valley; probably a minimum age

bsk

Basalt of Skull Creek (middle Pleistocene)Olivine-basalt $\left(49 \% \mathrm{SiO}_{2}\right)$ intracanyon lava flow, 80-120 m thick, forming steep walls of Trout Lake Creek just above its confluence with Skull Creek. Source unknown, probably in the Indian Heaven volcanic field west of map area. Cliffs have several, variously oriented, sets of spectacular columnar joints, which disintegrate into long coarse talus slopes. Rock is largely massive, finely crystalline, and nonvesicular. Phenocrysts: $3-5 \%$ olivine $(0.5-1.5 \mathrm{~mm})$, seriate to olivine-rich groundmass. Older than all contiguous Quaternary volcanic units; overlies or banks against Tertiary lavas and old intracanyon river-gravels. Undated

bsm Basalt of Swampy Meadows (middle Pleistocene)-Olivine-basalt $\left(48.5 \% \mathrm{SiO}_{2}\right)$ lava flows underlying a 3-by 5-km area at the west base of Mount Adams. Vent unknown, concealed but possibly local. Unit is severely glaciated and heavily mantled by drift and alluvium. Exposures are mostly nonvesicular, massive or slabby, crystalline, and as thick as $125 \mathrm{~m}$ on the western cliffs. Phenocrysts: $10-15 \%$ olivine $(0.5-2.5 \mathrm{~mm}$; rarely to $5 \mathrm{~mm})$, some in clusters; sparse plagioclase rarely larger than $0.5 \mathrm{~mm}$. Not in contact with any other Quaternary enuptive unit. K-Ar age: $518 \pm 14 \mathrm{ka}$

bsr Basalt west of Stagman Ridge (middle Pleistocene)-Pyroxene-olivine-basalt $\left(50 \% \mathrm{SiO}_{2}\right)$ lava-flow remnant poorly exposed beneath late Pleistocene glacial drift, $300-700 \mathrm{~m}$ east of White Salmon River, at western base of Stagman Ridge. Limited outcrops are crystalline, slightly to nonvesicular, slabby or massive, and glacially eroded. Source and direction of flow are unknown; chemically 
similar to unit bsm ( $2 \mathrm{~km}$ west), but units contrast petrographically and in age. Phenocrysts: $7 \%$ olivine $(0.5-1.5 \mathrm{~mm}) ; 5 \% \mathrm{cpx}$ (0.5-2 mm); $3-4 \%$ plag $(0.5-3 \mathrm{~mm}) ; 1 \%$ opx (0.5-1.5 mm); olivine-plag aggregates as large as $1 \mathrm{~cm}$ are common. Appears to rest on Tertiary rocks and to be overlain by driftmantled andesite lavas nearby. $\mathrm{K}$-Ar age: $145 \pm 20 \mathrm{ka}$

bst

Basalt of Stoller Canyon (middle or early Pleistocene)-Low-K olivine-basalt $\left(48 \% \mathrm{SiO}_{2}\right)$ lava flows and scoria of small isolated center above the southeast margin of Trout Lake Valley. Deeply weathered and soil covered, exposure is poor except at White Salmon River. No cinder cone, but scattered bombs and cinders mark a subdued vent, probably largely effusive. Lavas are diktytaxitic, slightly vesicular, and phenocryst-poor. Phenocrysts: $4 \%$ olivine $(0.5-1.5 \mathrm{~mm}$, mostly smaller than $1 \mathrm{~mm}$ ); iddingsitized rims common. Rests wholly on Columbia River Basalt Group; much younger bic lavas bank against the eroded terminus. Undated

btc Basalt of Trappers Creek (Holocene)-Olivine-plagioclase basalt $\left(49 \% \mathrm{SiO}_{2}\right)$ lava flows and ejecta erupted at Red Butte cinder-spatter cone on northeast flank of Mount Adams. Two main lava tongues, each consisting of many thin flows, extend $7 \mathrm{~km}$ north and $13 \mathrm{~km}$ northeast from the cone. Proximal flows are typically pahoehoe sheets less than $1 \mathrm{~m}$ thick; distal flows are rubbly, scoriaceous, as thick as $6 \mathrm{~m}$. As the tongues are little eroded, total thickness is poorly known, but maximum relief is $10-15 \mathrm{~m}$ on medial levees and northeast terminus. Phenocrysts: $8-12 \%$ plag $(0.5-2 \mathrm{~mm}$, rarely $3 \mathrm{~mm}) ; 5-10 \%$ olivine (0.5-1.5 $\mathrm{mm}$ ); sparse $\mathrm{cpx}$; olivine-plag clusters common. Overlies units adg, awf, bcl, bcw, bgb, and bsc; overlain by amf. Undated; early or middle Holocene

bts Basalt south of Trappers Creek (middle? Pleistocene)-Olivine-basalt $\left(50.5 \% \mathrm{SiO}_{2}\right)$ lava-flow remnant banked against Columbia River Basalt Group on southwest wall of Trappers Creek about $2 \mathrm{~km}$ upstream from confluence with Clearwater Creek. Source unknown; possibly north of map area. Rock is crystalline, diktytaxitic, with sparse vesicles to $1 \mathrm{~mm}$. Phenocrysts: $5 \%$ olivine $(0.5-$ $1.5 \mathrm{~mm}$ ); plag only in groundmass. Top of this glacially eroded, 50 -m-thick remnant is $60 \mathrm{~m}$ higher than a nearby intracanyon remnant of unit bgb $(68 \pm 10 \mathrm{ka})$. Overlain by unit awf $(55 \pm 7 \mathrm{ka})$. Undated

bwb Basalt of Wellenbrock Spring (early Pleistocene or Pliocene)-Olivine-basalt $(52 \%$ $\mathrm{SiO}_{2}$ ) lava flows at southeast margin of $\mathrm{Ca}$ mas Prairie, erupted from $8-\mathrm{km}$-wide shield centered $4 \mathrm{~km}$ east of map. Numerous thin shingled flows, weathered and poorly exposed, covered by thick rubbly colluvium and loessic soil. Phenocrysts: $2-3 \%$ olivine $(0.5-2 \mathrm{~mm})$, commonly in clusters; $6 \%$ plag $(0.5-2 \mathrm{~mm})$. Microlitic plag is conspicuous in groundmass, especially in weathered rocks. Vent is on crest of anticline in Columbia River Basalt Group (Anderson, 1987)

bwc Basalt west of Cakey Butte (middle Pleistocene)-Olivine-basalt $\left(51-52 \% \mathrm{SiO}_{2}\right)$ lava flows forming much of north rim of Trout Lake Creek between Cakey Butte and Skull Creek. Poorly exposed agglutinate and scoria mark two vent remnants along canyon rim south of Haystack Butte. Glacially eroded stacks of lavas, cumulatively as thick as $150 \mathrm{~m}$, crop out mostly as massive or slabby-jointed cliffs and ledges, which shed coarsely blocky talus slopes; sparse exposures of rubbly scoriaceous zones. Phenocrysts: $7-8 \%$ olivine $(0.5-1 \mathrm{~mm}$, rarely to $2.5 \mathrm{~mm})$, typically seriate to olivine-peppered groundmass. Chemically and petrographically similar to unit bcb but systematically poorer in $\mathrm{K}, \mathrm{Ti}, \mathrm{P}, \mathrm{Zr}$, and $\mathrm{Nb}$. Rests on Tertiary rocks and on unit acb; overlain by bcn. Undated but probably roughly contemporaneous with bcb $(246 \pm 19 \mathrm{ka})$

bwf Basalt of West Fork (middle Pleistocene)Low-K, sparsely porphyritic, olivine-basalt $\left(49-51 \% \mathrm{SiO}_{2}\right)$ lava flows exposed for $13 \mathrm{~km}$ along Klickitat River, from its lower West Fork as far south as Cunningham Creek. Source unknown, concealed by younger units to west or northwest. Intracanyon stack of several thin flows is cumulatively as thick as $70 \mathrm{~m}$; lavas are crystalline, diktytaxitic, vesicular with conspicuous secondary minerals, and extensively weathered. Phenocrysts: $1-2 \%$ olivine (0.5-1.5 mm); less than $1 \%$ plagioclase $(0.5$ $5 \mathrm{~mm}$ ); groundmass plagioclase conspicuous on weathered surfaces. Older than all contiguous Quaternary volcanic units. Surface is veneered by alluvium that antedates re-establishment of Klickitat River gorge (subsequently filled by lavas of unit bgb). K-Ar age: $500 \pm 34 \mathrm{ka}$

bws Basalt of White Salmon River gorge (middle Pleistocene)-Olivine-basalt $\left(49-51 \% \mathrm{SiO}_{2}\right)$ lava flows exposed on floor and lower walls of White Salmon River gorge in two windows, respectively near tributary junctions of Buck and Green Canyon Creeks. Olivine basalt exposed locally beneath unit acb on northeast wall of Trout Lake Creek is chemically and petrographically similar. Source and direction of flow are unknown; absence of these basalts in another window $2 \mathrm{~km}$ upgorge from Buck Creek weighs against an upstream derivation. Lavas are fluvially incised but not to their base; maximum thickness exposed is $8 \mathrm{~m}$ at Buck Creek and about $90 \mathrm{~m}$ near 
Green Canyon Creek. Outcrops are slabby, massive, weathered, iron stained, and contain abundant secondary minerals wherever vesicular or diktytaxitic. Phenocrysts: $5-8 \%$ olivine (0.5-1.5 mm); sparse cpx. Overlain by units amc, dcc, and aws (457 $\pm 11 \mathrm{ka})$. $\mathrm{K}-\mathrm{Ar}$ age: $557 \pm 18 \mathrm{ka}$

dac Dacite of Adams Creek (middle Pleistocene)Sparsely porphyritic pyroxene-dacite $163.5 \%$ $\mathrm{SiO}_{2}$ ) lava flow that forms east wall of Adams Creek gorge near confluence with its East Fork. Source unknown, probably to southeast, concealed by younger lavas. Unit is severely eroded, glacially stripped of its glassy carapace, and well exposed only on the gorge wall where it is thicker than $40 \mathrm{~m}$; its surface is largely covered by glacial and debrisflow deposits. Most outcrops are crystalline, nonvesicular, and very slabby to platy; exposures of massive or vesicular glassy zones are rare. Phenocrysts: $3 \%$ plag $(0.5-3 \mathrm{~mm}$, rarely to $7 \mathrm{~mm}$ ); less than $1 \%$ each of $\mathrm{cpx}$, opx, and olivine (all smaller than $1.5 \mathrm{~mm}$ ). Base not exposed; overlain by units akc and atm. $\mathrm{K}$-Ar age: $233 \pm 6 \mathrm{ka}$

dbc Dacite of Bird Creek Meadows (late Pleistocene)-Plagioclase-rich pyroxene-dacite (66$68 \% \mathrm{SiO}_{2}$ ) lava flow underlying much of Bird Creek Meadows. Everywhere ice-scoured, but surviving exposures extend $4 \mathrm{~km}$ southeast from Neoglacial moraine to near Mirror Lake. Lavas are largely crystalline, nonvesicular, platy, widely weathered and crumbly, iron stained on pervasive fractures, $\tan$ to creamy white on many ice-smoothed surfaces. Polygonally jointed upper and lower vitrophyres crop out near Bluff Lake and at "Viewpoint" above Hellroaring Meadow, respectively. Lava may have been emplaced in part subglacially. Cave near upper end of exposure is eroded along a fold axis in platy flow-foliation. Source vent uncertain, but a partly glassy intrusive mass on canyon wall $300 \mathrm{~m}$ north of "Viewpoint" is compositionally similar. Phenocrysts: $24 \%$ plag $(0.5-4 \mathrm{~mm}) ; 3 \% \mathrm{cpx}(0.5-2.5 \mathrm{~mm}) ; 6 \%$ opx (0.5-1.5 mm); $1 \% \mathrm{Fe}$-Ti oxides (less than $0.5 \mathrm{~mm}$ ); sparse quartz and olivine, both rounded and smaller than $1 \mathrm{~mm}$. Younger than all contiguous volcanic units except app. $\mathrm{K} \mathrm{Ar}$ age: $115 \pm 5 \mathrm{ka}$ Sparsely porphyritic pyroxene-dacite $(64-65 \%$ $\mathrm{SiO}_{2}$ ) lava flow and agglutinate erupted high on southwest flank of Mount Adams. From proximal agglutinates exposed below Avalanche Glacier moraines, lava-flow remnants extend farther than $22 \mathrm{~km}$ down Salt, Cascade, and Green Canyon Creeks and along White Salmon River, probably originally into Trout Lake Valley. Glaciated cliffs of stratified near-vent agglutinate are $25-70 \mathrm{~m}$ thick, rich in lithic

fragments, moderately to densely welded, finely crystalline or glassy, partly eutaxitic, and in part rheomorphic. Intracanyon lava is as thick as $70 \mathrm{~m}$ medially and $25 \mathrm{~m}$ distally; mostly finely crystalline, nonvesicular, massive, platy or slabby, and flow banded; typically medium gray with light gray mottles; glassy base, margins, and welded basal breccia are exposed locally. Phenocrysts: $3-5 \%$ plag $10.5-2 \mathrm{~mm}$, rarely to $4 \mathrm{~mm}$ ); less than $0.5 \%$ each opx and cpx (to $1 \mathrm{~mm}$ ); sparse $\mathrm{Fe}$-Ti oxides (to $0.5 \mathrm{~mm}$ ). Banked against units all, aws, bcb, acb, bws, bco, and bhb; overlain by amc and app. Medially and distally covered by pre-Evans Creek drift (go). K-Ar age: $117 \pm 6$ ka

$d d c$

dhe

dhd

Dacite of Hellroaring Ditch (middle Pleistocene)-Sparsely porphyritic dacite $(63.5 \%$ $\mathrm{SiO}_{2}$ ) lava flow, north of King Mountain shield. Known length $13 \mathrm{~km}$, but source is concealed by younger units on southeast flank of Mount Adams; highest exposure is at 6300' $(1920 \mathrm{~m})$ in Bird Creek Meadows. McCumber Spring issues from blocky snout, atop unit bms at $2350^{\prime}(715 \mathrm{~m})$. Where unglaciated, flow is $20-50 \mathrm{~m}$ thick, blocky and glassy, with a coarsely vesicular carapace in which vesicles are commonly stretched and flattened to resemble scaly tree-bark. Above till limits, most exposures are of the massive to flow-banded, devitrified interior, typically slabby with tan or pale greenish-gray mottles. Phenocrysts: $5 \%$ plag $(0.5-5 \mathrm{~mm}) ; 1 \%$ olivine (smaller than $0.8 \mathrm{~mm}$, partially resorbed); 
and traces of cpx and Fe-Ti oxides. Younger than contiguous volcanic units except abl, aeb, dss, and dbc. K-Ar age: $304 \pm 5 \mathrm{ka}$

Dacite of Hole-in-the-Ground Creek (middle Pleistocene)-Sparsely porphyritic pyroxene-dacite $\left(63-64 \% \mathrm{SiO}_{2}\right.$ ) lava flow, poorly exposed west of Gotchen Creek, 4-6 km northnortheast of Trout Lake. Vent concealed by younger units, presumably farther north. Lavas are widely covered by drift, alluvium, and loessic soil; most exposures are massive, flow banded, and either finely crystalline or black vitrophyre, with local remnants of vesicular carapace. Phenocrysts: $2 \%$ plag $(0.5-1.5 \mathrm{~mm})$; sparse olivine, cpx, and opx (all smaller than $1 \mathrm{~mm}$ ). Flow wrapped around Big Tree kipuka (knob 2896) but had been erosively incised before emplacement of unit bew ( $329 \pm 50 \mathrm{ka})$. Overlain by units bew, ahg, and bsb. Undated

dlm Dacite of Little Muddy Creek (middle Pleistocene)-Plagioclase-rich pyroxene-dacite $\left(66.5 \% \mathrm{SiO}_{2}\right)$ lava flow exposed only along a 250-m-long reach of south fork of Little Muddy Creek, about $1.5 \mathrm{~km}$ east-northeast of snout of Wilson Glacier. Source concealed beneath main cone of Mount Adams. Ledges along both sides of creek are crystalline, massive, slabby, and commonly weathered, with iron staining along cracks. Unit is glacially scoured and till mantled, but maximum incised relief is only about $6 \mathrm{~m}$; base not exposed. Phenocrysts: $20-22 \%$ plag $(0.5-$ $5 \mathrm{~mm}) ; 1 \%$ each opx and $\mathrm{cpx}(0.5-1 \mathrm{~mm})$; sparse olivine (smaller than $1 \mathrm{~mm}$ ) and $\mathrm{Fe}$ $\mathrm{Ti}$ oxides. Older than all contiguous units; overlain directly by units alm and bgt $(159 \pm 31 \mathrm{ka})$. Undated

dir Dacite of Lewis River (middle Pleistocene)Sparsely porphyritic pyroxene-dacite $(63 \%$ $\mathrm{SiO}_{2}$ ) lava flows that crop out in two tongues, along Riley Creek and in small windows along upper Lewis River. Source is concealed by younger lavas to southeast. Each tongue is a single lava flow, $15-50 \mathrm{~m}$ thick, chemically and lithologically identical, glacially eroded, and largely stripped of any glassy carapace. Exposures are massive, nonvesicular, finely crystalline, slabby to platy, and light to dark gray with pale-gray mottles common; black obsidian preserved locally. Lavas rest upon syneruptive glassy debrisflow material 10-15 m thick at Riley Creek and $5 \mathrm{~m}$ thick where exposed at $4260^{\prime}$ along Lewis River. These unstratified deposits contain $10-20 \%$ variably rounded andesitic pebbles and boulders entrained from stream gravels but consist predominantly of black dacite glass granulated to angular sand and fragments as big as $3 \mathrm{~cm}$; clayey weathering of subordinate fine glass imparts a paleorange-brown color to undisturbed surfaces.
Phenocrysts: $2 \%$ plag $(0.5-2 \mathrm{~mm}) ; 0.5 \%$ each of cpx (0.5-1.5 mm) and olivine $(0.5-0.75 \mathrm{~mm})$; sparse Fe-Ti oxides. Unit rests on Tertiary andesitic rocks, on unit arc, or (at 4250' on Lewis River) on 10-12 m of stratified fluvial and pond sediments; overlain by units alw, brc, asc, and atm. K-Ar age: $252 \pm 8 \mathrm{ka}$

dnc Dacite north of Cress Camp (middle or early Pleistocene?)-Phenocryst-poor low-K hornblende-dacite $\left(63.5 \% \mathrm{SiO}_{2}\right)$ lava, poorly exposed just below late Pleistocene moraine limit north of Cougar Creek. Abundant rubbly monolithologic colluvium, with little relief or true outcrop. Phenocrysts: $2 \%$ plag $(0.5-$ $1.5 \mathrm{~mm}$ ); $1 \%$ hornblende (as long as 0.75 $\mathrm{mm}$ ); both are also abundant as microphenocrysts in a glassy groundmass, the tiny plag being conspicuous on weathered surfaces. This is one of only two hornblende-bearing eruptive units in the Mount Adams area. Rests on Columbia River Basalt Group; overlain by unit bcc and by late Pleistocene till (gy). Undated; conceivably pre-Quaternary

Dacite of Olallie Lake (middle Pleistocene)Moderately porphyritic pyroxene-dacite $166 \%$ $\mathrm{SiO}_{2}$ ) lava flow at northwest base of Mount Adams, forming a simple 4- by 3-km coulee as thick as $160 \mathrm{~m}$. Largely stripped of its glassy carapace, flow surface is covered by thick colluvium, soil, and locally by till, thus obscuring the vent-which may lie beneath or near Takh Lakh Lake. Exposures are mostly crystalline, nonvesicular, platy to slabby; glassy basal zone is exposed locally at periphery. Phenocrysts: $8-12 \%$ plag (mostly smaller than $2 \mathrm{~mm}$, rarely to $5 \mathrm{~mm}$ ); less than $1 \%$ each opx and $\mathrm{cpx}(0.5-2 \mathrm{~mm}) ; 1 \% \mathrm{Fe}$-Ti oxides $(0.2-0.8 \mathrm{~mm})$. Older than all contiguous Quaternary volcanic units. K-Ar age: $381 \pm 5 \mathrm{ka}$

dsc

Dacite of Sheep Creek (middle Pleistocene)-Pyroxene-dacite $\left(63 \% \mathrm{SiO}_{2}\right)$ lava flow preserved as several glaciated remnants at the head of East Canyon Creek and as a dissected intracanyon flow along Sheep Creek. Vent unknown, concealed by younger units to southeast. Remaining outcrops define a 6-km-long tongue extending nearly to Adams Creek, supporting falls and cascades. Exposures are crystalline, platy, locally columnar, covered with till, colluvium, and loessic soil. Phenocrysts: $15 \%$ plag $(0.5-$ $3 \mathrm{~mm}$ ); $2.5 \%$ each of opx and cpx (both 0.5 $2 \mathrm{~mm}$ ); sparse olivine and $\mathrm{Fe}$-Ti oxides; intergrown plag-pyroxene clusters $(4-10 \mathrm{~mm})$ common. Rests largely on Tertiary rocks; banks against older unit dol ( $381 \pm 5 \mathrm{ka})$. K-Ar age: $246 \pm 4 \mathrm{ka}$, distally. Age is similar to that of nearby unit alw

dss

Dacite southeast of Snowplow Mountain (late or middle Pleistocene)-Pyroxene-dacite $\left(64 \% \mathrm{SiO}_{2}\right)$ lava flow cropping out in win- 
dow between Bird and Dry Creeks. Vent unknown, covered by till or younger lavas to northwest. Overlapped by late Pleistocene moraines, but most exposures below glacial limit are blocky and still partly glassy and vesicular (although weathered, loess-mantled, and having local stream-incision into the slabby crystalline interior). Phenocrysts: $21 \%$ plagioclase $(0.5-2 \mathrm{~mm}$; rarely to $6 \mathrm{~mm}) ; 2 \%$ opx (0.5-2.5 mm); sparse $\mathrm{cpx}$ and $\mathrm{Fe}$ - $\mathrm{Ti}$ oxides. Overlain by unit bkm (106 $\pm 25 \mathrm{ka})$; overlies bbj and dhd ( $304 \pm 5 \mathrm{ka})$. Undated

dsw

Dacite of Swampy Creek (middle Pleistocene)-Moderately porphyritic pyroxenedacite $\left(63 \% \mathrm{SiO}_{2}\right)$ lava flow exposed on slopes above head of North Fork of Swampy Creek. Source concealed by till and younger lavas, presumably to the east. Glacially scoured, till-mantled remnant is poorly exposed, possibly as thick as $25 \mathrm{~m}$; exposures are finely crystalline or partly glassy, nonvesicular, slabby to platy, and commonly vaguely flow banded and mottled. Phenocrysts: $8-10 \%$ plag (0.5-4 mm); less than $1 \%$ each cpx and opx (0.5-1 mm). Rests on Tertiary lavas; overlain by unit atf $(137 \pm 6 \mathrm{ka})$. Undated

dth Dacite tuff of Hellroaring Creek (middle Pleistocene)-Pyroxene-dacite $\left(67 \% \mathrm{SiO}_{2}\right)$ nonwelded pumiceous pyroclastic-flow deposit intercalated between lava flows of unit ahv, about $1 \mathrm{~km}$ below snout of Mazama Glacier. Dibekulewe tephra may be downwind fallout equivalent. Conspicuous white to pale-yellowish-orange deposit, 10-15 m thick, crops out near base of cliffs west-northwest of Hellroaring Meadow. Middle $4 \mathrm{~m}$ is poorly sorted and unstratified; lowest $8 \mathrm{~m}$ and top 2-3 $\mathrm{m}$ are layered and lenticular but still poorly sorted, reflecting several primary emplacement pulses and (at the top) minor sloughing or sheetwash. Crude stratification is largely imparted by lenses and layers rich in lithic fragments that segregated from moving flows. Lithics make up 5-25 volume \% of various flow units, are generally matrix supported, and are mostly $1-10 \mathrm{~cm}$ but as big as $40 \mathrm{~cm}$, being coarsest in the poorly exposed lower stratified interval. Most lithics are cognate dacite vitrophyre, subangular to subrounded, but include accidentally entrained andesites. Subordinate but abundant pumice is mostly $1-5 \mathrm{~cm}$ but as big as $30 \mathrm{~cm}$, pervasively punky, and extensively altered to montmorillonite and opal-as is the enclosing ashy matrix. Phenocrysts in vitrophyric clasts: $20-27 \%$ plag $(1-2.5 \mathrm{~mm}) ; 2 \%$ opx $(0.5-1 \mathrm{~mm}) ; 1 \% \mathrm{cpx}(0.5-$ $1 \mathrm{~mm})$; and $1 \% \mathrm{Fe}$-Ti oxides (0.25-0.5 mm). Deposit resulted from a single eruption, in a style unique at Mount Adams. It is underlain and overlain by lava flows of unit ahv $(0.5 \mathrm{Ma})$, dips $10^{\circ}-20^{\circ}$ WSW away from center of deeply eroded Hellroaring Volcano (see ahv), and is intruded and locally fused by dikes of unit adh

dts Dacite of The Spearhead (middle Pleistocene)-Pyroxene-dacite $\left(62-63.5 \% \mathrm{SiO}_{2}\right)$ lava-flow-breccia sheets forming a 300-m-high glacially eroded crag (and nearby remnants) on Battlement Ridge. Main crag (The Spearhead) is divided by northwest-dipping, finely brecciated, shear zones into two thick subunits and a thinner capping one. The middle and capping subunits, weathering rusty orange-brown to ochre, retain irregular massive domains $1-10 \mathrm{~m}$ thick but consist predominantly of coarse flow breccia, which is rich in angular $0.1-2 \mathrm{~m}$ clasts and typically contains less than $20 \%$ comminuted matrix. Lowest subunit weathers dark gray to brown, contains fewer large clasts and no massive zones, and consists of several breccia sheets, each 5-10 m thick, some showing crude normal grading. Clasts throughout dts are slightly to moderately vesicular, glassy or partly so, and lightly altered hydrothermally-increasingly so upward but only superficially so relative to the more altered, orange-brown matrix. Phenocrysts: Upper subunits have $25 \%$ plag (0.5-2 mm), 3\% opx and $1 \% \mathrm{cpx}$ (both smaller than $1 \mathrm{~mm}$ ); clasts in lower subunit and southeast outlier have only $4 \%$ plag $(0.5-2$ $\mathrm{mm}), 1 \%$ opx $(0.5-2 \mathrm{~mm})$, and $0.2 \% \mathrm{cpx}$ (0.5-1.5 mm); pyroxene and Fe-Ti-oxide microphenocrysts are abundant in glassy groundmass of all subunits. Exposures are isolated and surrounded by till, talus, and younger lavas; base of unit is nowhere exposed. Probably erupted from Hellroaring Volcano; the breccias dip toward the present Mount Adams, apparently away from an eroded center that stood above the present site of upper Big Muddy Creek. The Spearhead is cut by a vertical swarm of thin andesitic dikes, as are extensive exposures of unit ahv $2 \mathrm{~km}$ south-southeast. $\mathrm{K}-\mathrm{Ar}$ age: $474 \pm 12 \mathrm{ka}$

Trc Rhyolite of Clearwater Creek (Pliocene)Phenocryst-rich rhyolite $\left(72 \% \mathrm{SiO}_{2}\right)$ lava flow or dome, poorly exposed as a $0.06-\mathrm{km}^{2}$ kipuka at northeast margin of Muddy Fork flow (amf). Rounded outcrops are weathered and crumbly, glacially stripped of glassy carapace, and extensively mantled by drift and soil. Phenocrysts: $8-10 \%$ quartz $(0.5-2.5 \mathrm{~mm})$, mostly rounded; $5-6 \%$ each of sanidine and plagioclase (both 0.5-3 mm); 0.5\% cpx (0.5-2.5 mm); and less than $0.5 \%$ each of amphibole and biotite, both severely oxidized and mostly smaller than $1 \mathrm{~mm}$. Older than all contiguous units. $\mathrm{K}-\mathrm{Ar}$ age: $3.14 \pm 0.04 \mathrm{Ma}$

Trg Rhyolite of Green Canyon (Pliocene or Miocene)-Sparsely porphyritic rhyolite $\left(72 \% \mathrm{SiO}_{2}\right)$ dome and lava-flow remnants, 2 $\mathrm{km}$ east of White Salmon River near south edge of map. Poorly exposed, deeply weath- 
ered, soil-covered, much removed by erosion; no glassy carapace preserved. Rocks are massive or slightly vesicular felsite, light gray to pale greenish gray, weathering white with rusty speckles. Phenocrysts: $4 \%$ plag $(0.5-2 \mathrm{~mm})$, mostly argillized chalky white; microphenocrysts of opx and $\mathrm{Fe}$ - $\mathrm{Ti}$ oxides (less than $0.5 \%$ each, rarely larger than $0.3 \mathrm{~mm}$ ). Emplaced through and upon 15-Ma lavas of the Columbia River Basalt Group. Undated; probably Late Miocene or Pliocene

Trm Rhyolite of Mann Butte (Oligocene)-Aphyric high-silica rhyolite $\left(76 \% \mathrm{SiO}_{2}\right)$ of Mann Butte dome, near southwest edge of map. Dome is $350 \mathrm{~m}$ high, $2.5 \mathrm{~km}$ in diameter; stripped of any vesicular or glassy carapace, its lavas are massive or flow banded, aphanitic felsite. Extensively argillized, the rocks are dominantly white with ubiquitous yellow-brown oxidation along pervasive fractures; sparse blocks have less-altered, pale lavender-to-gray cores. Phenocrysts: $0-4 \%$ plag $(0.5-2 \mathrm{~mm}$, rarely to $4 \mathrm{~mm}$ ); traces of quartz, sanidine, zircon (all smaller than $1 \mathrm{~mm}$ ). K-Ar age: $29.9 \pm 0.2 \mathrm{Ma}$

$\mathrm{Ttm}$ Tuff of Midway Creek (Pliocene)-Pyroxenedacite $\left(67 \% \mathrm{SiO}_{2}\right)$ ignimbrite exposed along and north of Midway Creek and on knob
$5018,2 \mathrm{~km}$ east-southeast of Potato Hill. Source unknown, possibly in the Goat Rocks volcanic field 5-15 $\mathrm{km}$ north of map edge. Basal $1.5 \mathrm{~m}$ is nonwelded to partially welded, ash-rich, with few pumice lapilli larger than $1 \mathrm{~cm}$. Most outcrops are moderately to densely welded, dark gray to brownish black, with abundant black, glassy, crystal-poor fiamme; matrix is typically rich in lithics and plagioclase crystals. Phenocrysts: Welded rimrock at Midway Creek (containing 15\% lithics) yields a lithic-free count of $14 \%$ plag $(0.5-3 \mathrm{~mm}), 1.2 \% \mathrm{cpx}(0.5-1.5 \mathrm{~mm}), 0.7 \%$ Fe-Ti oxides $(0.3-0.5 \mathrm{~mm})$, and traces of opx and quartz (both $0.5-1 \mathrm{~mm}$ ). Unit is drift strewn and soil covered. Thickness $6 \mathrm{~m}$ at Midway Creek; reportedly as much as $23 \mathrm{~m}$ elsewhere (Hammond, 1980). K-Ar age: $3.65 \pm 0.4 \mathrm{Ma}$ (Hammond, 1980)

Tvs Volcanic and sedimentary rocks, undivided (Tertiary)-Consists predominantly of: (1) Pliocene basalts in northeastern part of map; (2) Miocene Columbia River Basalt Group in south and east; and (3) Oligocene and Miocene Cascade arc assemblages in the west (Walsh and others, 1987) 
